\title{
ANÁLISE QUANTITATIVA DO CRESCIMENTO DO CULTIVAR AG 401 (Zea mays L.) SOB DIFERENTES SISTEMAS DE PREPARO DO SOLO E POPULAÇÃO DE PLANTAS
}

\author{
PAULO AUGUSTO MANFRON
}

Orientador: PAULO LEONEL LIBARDI

Dissertação apresentada à Escola Superior de Agricultura "Luiz de Queiroz", da Universidade de São Paulo, para obtenção do título de Mestre em Agronomia. Área de Concentração: Agrometeorologia.

$P \mid R A C I C A B A$

Estado de São Paulo - Brasil

Outubro de 1985 
Aos meus pais, Augusto e In $\vec{a}$.

que com muita dedicação

souberam mostrar os caminhos da

responsabilidade e perseverança,

por vezes, caminhos penosos,

porēm gratificantes

A esposa, Melânia,

que sempre incentivou e

dedicadamente auxiliou

na escolha de soluções

para os problemas

Aos meus filhos, Fernando e Rafael,

cue são a razão de

todos os esforgos 


\section{AGRADECIMENTOS}

- Ao Prof. Dx. paulo Leonel Libardi, pelo incentivo, orientação e amizade, que contribüram para minha formação.

- Ao Engo Agro Eloy Antonio Pauletto, pela labuta diäria, cooperação e a grande amizade que nos cerca.

- Aos colegas e amigos do Departamento de Fitotecnia do Cen tro de Ciências Rurais da universidade Federal de Santa Maria, especialmente a Ailo Valmir Saccol, Arno Bernardo Heldwein, Flávio Miguel Schneider, Galileo Adeli Buriol e Valduino Estefanel, pelo incentivo e cooperação.

- Aos Professores do Departamento de Física e Meteorologia da Escola Superior de Agricultura "Luiz de Queiroz" que, pelo seu esforço, experiência e amizade, contribuíram pa ra minha formação.

- Aos amigos Sergio Oliveira Moraes, Eduardo Caruso Machado, João Eduardo Pilotto, José Ademir Rodrigues, Daciano Stenico, Hermes Alves Almeida e Otávio Minoru Matsumoto, pela cooperação e companheirismo.

- Aos colegas do curso de Pós-Graduação em Agrometeorologia, pela convivência sadia. 
- Aos funcionärios Luiz Angeleli e Manoel Israel, pela ajuda no experimento em sua parte de campo.

- A minha sogra, Jeni Vigil Palermo, pelo incentivo e ajuda nas horas difíceis.

- À Universidade Federal de Santa Maria e à Escola Superior de Agricultura "Luiz de Queiroz", pela oportunidade de rea lização do curso.

- Ao Plano Institucional de Capacitação Docente da CAPES, pe lo auxilio financeiro.

- Em especial, agradeço Eloy Antonio Pauletto, Clara Manfron Morosini, Ailo Valmir Saccol e familia, Almiro Almirante zigler e familia, Paulo Leonel Libardi e familia e Marcelo dos Santos e familia. 


\section{INDICE}

$\underline{\text { Pàgina }}$

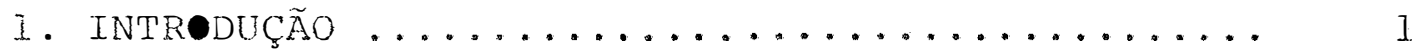

2. REVISÃO DE LITERATURA .................. 4

2.1. Efeitos ambientais no desenvolvimento do

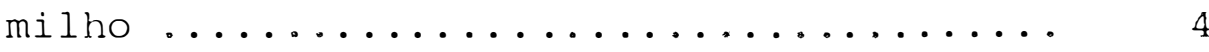

2.2. Influência do sistema de preparo do solo na produtividade do milho $\ldots \ldots \ldots \ldots$

2.3. Densidade de plantas ............... 13

2.4. Comportamento dos parâmetros fisiolögicos

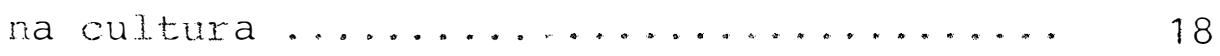

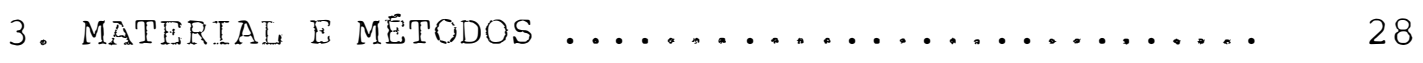

3.1. Localização da ärea experimental ....... 28

3.2. Caracterização da ärea experimental ..... 28

3.2.1. Dimensões da ārea experimental .... 30

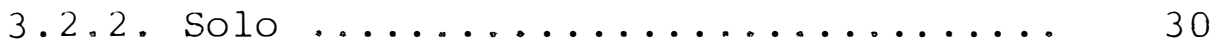

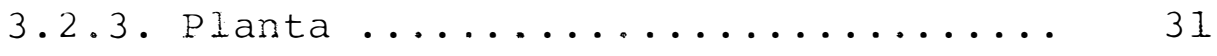

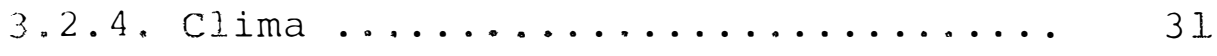

3.3. Instalação do experimento ........... 32

3.3.1. Preparo do solo ................ 32

3.3.2. Semeadura e população de plantas ... 33

3.4. Práticas culturais ................ 34

3.4 .1 . Adubação ...................... 34

3.4.2. Capinas, aplicações de defensivos e amontoa .................... 34

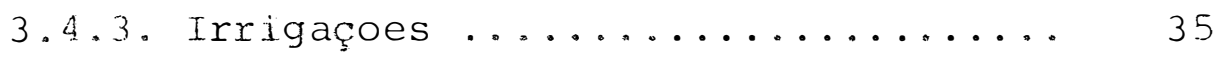


$\underline{\text { Pägina }}$

3.5 . Determinaçōes realizadas .......... 37

3.5.1. Fenologia ................. 37

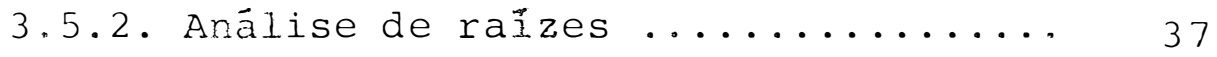

3.5.3. Radiação solar e precipitação ..... 39

3.5.4. Características morfológicas ..... 39

3.5.5. Matéria seca .................4 40

3.5.6. Area foliar ................. 40

3.5.7. Produção por ārea ............. 41

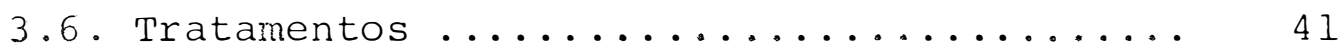

3.6.1. Delineamento experimental ....... 42

3.7. Obtenção de parâmetros fisiológicos ...... 42

3.7.1. Indice de Area Foliar (IAF) ...... 43

3.7.2. Produtividade Biológica (PB) ..... 43

3.7.3. Taxa de Crescimento da Cultura (TCC) . 43

3.7.4. Taxa de Crescimento Relativo (TCR) .. 44

3.7.5. Taxa de Assimilação Líquida (TAL) .. 44

3.7.6. Razão de Área Foliar (RAF) ....... 45

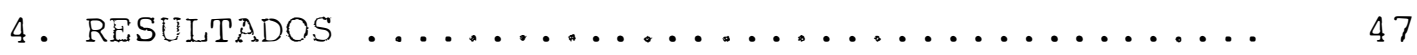

4.1. Condições meteorológicas ............. 47

4.2. Características morfolögicas ........... 49

4.2.1. Altura das plantas ............ 49

4.2 .2 . Número de folhas .............. 49

4.2.3. Número de espigas por planta ..... 52

4.2.4. Fenologia 52

4.3. Distribuição de raizes .............. 55

4.4. Matéria Seca 55

4.4.1. Matëria seca dos colmos 55

4.4.2. Matëria seca das folhas 62 
$\underline{\text { Pägina }}$

4.4.3. Matéria seca total ............ 68

4.5. Parâmetros fisiolögicos ............. 68

4.5.1. Indice de ärea foliar .......... 68

4.5.2. Produtividade biolögica ......... 74

4.5.3. Taxa de crescimento da cultura .... 80

4.5.4. Taxa de crescimento relativo ...... 80

4.5.5. Taxa de assimilação Iíquida ...... 85

4.5.6. Razão de ärea foliar ........... 85

4.6. Produção por ärea ................. 90

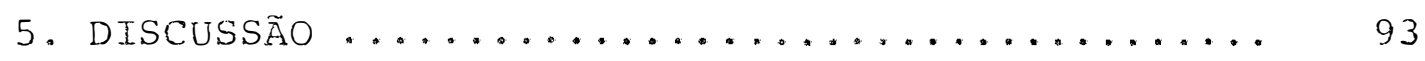

5.1. Radiação solar e precipitação .......... 93

5.2. Matéria seca .................... 94

5.3. Caracteristicas morfológicas ........... 96

5.4. Fenologia ...................... 97

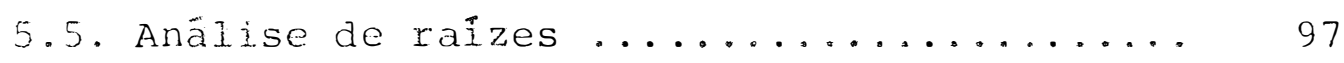

5.6. Parâmetros fisiológicos .............. 98

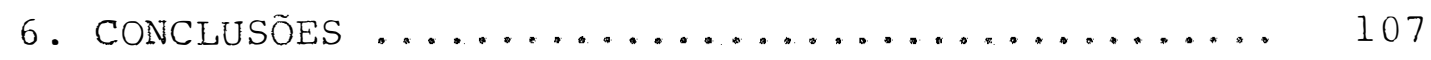

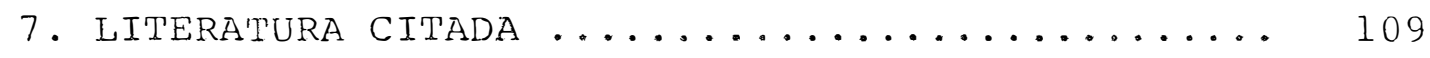




\section{LISTA DAS TABELAS}

Tabela

Pägina

1 Identificação dos estãdios de desenvolvimento de uma cultura de milho (zea mays, L.), segundo HANWAY (1963). Piracicaba,

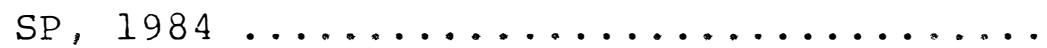

2 - Valores médios de altura de plantas e nümero de folhas por planta, para as coletas do preparo do solo convencional, nos espaçamentos $0,70,0,90$ e $1,10 \mathrm{~m}$, em miIho (Zea mays L.) . Piracicaba, SP, 1984 ..

3 - Valores médios de altura de plantas e número de folhas por planta, para as coletas do preparo do solo com subsolagem, nos espaçamentos entre linhas de $0,70,0,90$ $€ 1,10 \mathrm{~m}$, em milho (Zea mays L.). Piracicaba, sp, $1984 \ldots \ldots \ldots \ldots \ldots \ldots \ldots \ldots \ldots \ldots \ldots \ldots \ldots \ldots \ldots$

4 - Valores médios do nümero de espigas por planta e por metro quadrado, nos diversos tratamentos estudados em milho (Zea mays, L.), cultivado em um solo classificado como "Terra Roxa Estruturada" série "Luizde Queiroz". Piracicaba, SP, $1984 \ldots \ldots \ldots \ldots$ 
5 - Datas de emergencia, início e Eim dos estádios vegetativos e reprodutivos e maturaçäo fisiolögica (HANWAY, 1963), para uma cultura de milho (Zea mays. I..), nos preparos do solo (convencional e subsolagem), em espaçamentos entre-linhas de $0,70,0,90$ e $1,10 \mathrm{~m}$. Piracicaba, SP,

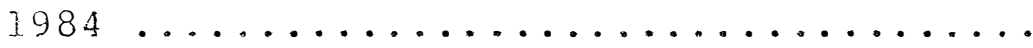

6 - Distribuição porcentual de raízes no perfil do solo atë a profundidade de $100 \mathrm{~cm}$, massa, em gramas, de raízes secas por camada de solo e profundidade mäxima do per fil onde foram visualizadas raỉzes, nos dois sistemas de preparo do solo (convencional e subsolagem), no espaçamento entre--Iinhas de $0,90 \mathrm{~m}$, para a cultura de mi Iho (Zea mays L.).Piracicaba, SP, 1984 ...

7 - Massa de matéria seca média das coletas de colmos, folhas e totais, nos diversos espaçamentos entre-linhas do preparo convencional, em milho (zea mays L.). Piracicaba, $S P, 1984 \ldots \ldots \ldots \ldots \ldots \ldots$

8 - Massa de matëria seca média das coletas 
de colmos, folhas e totais, nos diversos espacanentos entre-linhas do preparo com subsolagem, em milho (zea mays I.). Piracicaba, $s p, 1984 \ldots \ldots \ldots \ldots \ldots$

9 - Coeficientes do modelo ( $\left.w f=a+b t+c t^{2}\right)$ e coeficientes de determinação $\left(R^{2}\right)$ para a mas sa da matéria seca das folhas (Wf), para os diversos tratamentos em função do número de dias decorridos após emergência (t); em miIho (Zea mays L.) . Piracicaba, SP, $1984 \ldots$

10 - Coeficientes do modelo ( $w c=a+b t)$ e coeficientes de determinação $\left(R^{2}\right)$ para a massa de matēria seca dos colmos (WC), para os diver sos tratamentos em funçăo do nümero de dias decorridos após emergência (t), em milho (Zea mays L.) . Piracicaba, SP, 1984 ....

11 - Coeficiente do modelo (WT $=a+b t$ e coefi cientes de determinação $\left(\mathrm{R}^{2}\right)$, para a massa da matéria seca total da parte aérea das plan tas (Wt) para os diversos tratamentos, em função do número de dias decorridos apos a emergência ( $t$ ), em milho (Zea mays L.). Piracicaba, SP, 1984 
12 - Valores médios do Indice de Area Foliar, nas datas de coletas dos diversos tratamentos, em milho (Zea mays L.). Piracicaba, $S P, 1984 \ldots \ldots \ldots \ldots \ldots \ldots \ldots$

13 - Coeficientes do modelo (IAF=a" $+b^{\prime \prime} t+c^{\prime \prime} t^{2}$ ) e coeficientes de determinação $\left(R^{2}\right)$, para o indice de ärea foliar (IAF), nos diversos txatamentos, em função do nümero de dias decorridos apös a emergência (t) em mitho (Zea mays L.) . Piracicaba, SP, 1984 ..

14 - Coeficientes do modelo $(\mathrm{PB}=\mathrm{a}+\mathrm{bt})$ e coeficientes de determinação $\left(R^{2}\right)$, para a pro dutividade biológica (PB), nos diversos trạ tamentos, em relação ao número de dias de corridos apōs a emergência (t), em milho (Zea mays I.). Piracicaba, SP, $1984 \ldots .$.

15 - Valores médios obtidos, em $\mathrm{g} \cdot \mathrm{m}^{-2}$, para a produtividade biológica $(\mathrm{PB})$, nas datas de coletas dos diversos tratamentos, em milho (Zea mays L.). Piracicaba, SP, 1984.

16 - Valores nédios obtidos experimentalmente, em $\mathrm{dm}^{2}$. $9^{-1}$, para a razão de ärea foliar (RAE'), nas datas 
de coletas dos diversos tratamentos, emmi Lho (Zea mays L.). Piracicaba, SP, $1984 \ldots$

17 - valores médios da produçäo por hectare, nos divexsos tratamentos estudados em mitho (zea mays L.), cultivado em um solo classificado como "Terra Roxa Estruturada" série "Luiz de Queiroz". Piracicaba, SP, $1984 \ldots \ldots \ldots \ldots \ldots \ldots \ldots \ldots \ldots \ldots \ldots \ldots \ldots \ldots \ldots \ldots \ldots \ldots$ 


\section{IISTA DAS FIGURAS}

Eigura

$\underline{\text { pàgina }}$

1 - Dimensões da ärea experimental, sob dois sistemas de preparo do solo: convencional (superior) e com subsolagem (inferior). Dis tribuição dos tensiômetros na ordem crescente de profundidades. Espaçamentos entre-Iinhas e distribuição dos aspersores para irrigação durante o ciclo do milho (Zea mays $\left.I_{.}\right) \ldots \ldots \ldots \ldots \ldots \ldots$

2 - Diagrama demonstrativo do arranjamento dos monólitos de solo, para retirada do solo e raizes de milho, em um solo classificado co mo "Terra Roxa Estruturada", série "Luiz de Queiroz" $\ldots \ldots \ldots \ldots \ldots \ldots \ldots \ldots \ldots$

3 - Valores de precipitação pluviométrica diária e decadais médios de radiação solar global durante o ciclo de uma cultura de milho (Zea mays $\left.L_{0}\right) \ldots \ldots \ldots \ldots \ldots \ldots$

4 - Massa média de matéria seca dos colmos em gramas, para o tratamento convencional, nos diversos espaçamentos, em uma cultura de milho (Zea mays L.), durante o ciclo em

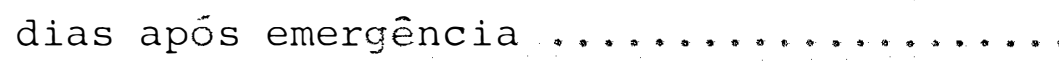


5 - Massa média de matéria seca dos colmos em gramas, para o tratamento com subsolagem, nos diversos espaçamentos, em uma cultura de milho (Zea mays $I_{.}$) , durante o ciclo

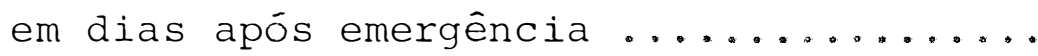

6 - Massa média de matéria seca das folhas em gramas, para os dois sistemas de preparo do solo, no espaçamento entre-linhas de $0,70 \mathrm{~m}$, em uma cultura de milho Zea mays I.), durante o ciclo em dias após emergên cia $\ldots \ldots \ldots \ldots \ldots \ldots \ldots \ldots \ldots \ldots$

7 - Massa média de matéria seca das folhas em gramas, para os dois sistemas de preparo do solo, no espaçamento entre-linhas de $0,90 \mathrm{~m}$, em uma cultura de milho (Zea mays L.), du rante o ciclo em dias após emergência ...

8 - Massa média de matéria seca das folhas em gramas, para os dois sistemas de preparo do solo, no espaçamento entre-linhas de 1,10 m, em uma cultura de milho (Zea mays L.), du rante o ciclo em dias após emergência ...

9 - Massa média de matéria seca total das plan tas em gramas, para o tratamento convencio 
nal, nos diversos espaçamentos, em uma cultura de milho (Zea mays L.), durante o ci-

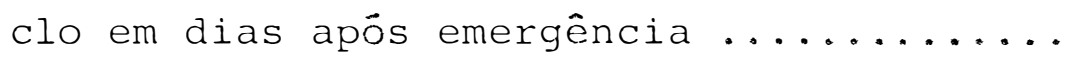

10 - Massa média de matéria seca total das plan tas, em gramas para o tratamento com subso lagem, nos diversos espaçamentos, em uma cultura de milho (Zea mays L.), durante o

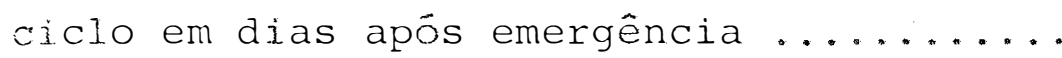

Il - Indice de Ãrea Foliar (IAF), média para o tratamento convencional, nos diversos espa Gamentos, em uma cultura de milho lzea mays L.), durante o ciclo en dias apös emer-

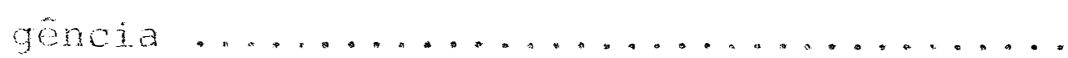

12 - Indice de Área Foliar (IAF), mëdia para o tratamento com subsolagem, nos diversos es paçamentos, em uma cultura de milho lzea mays L.), durante o ciclo em dias apös emergência $\ldots \ldots \ldots \ldots \ldots \ldots \ldots \ldots \ldots \ldots \ldots \ldots \ldots \ldots \ldots \ldots \ldots \ldots$

13 - Produtividade Biolögica (PB), média para o tratamento convencional, nos diversos espa çamentos, em uma cultura de milho (zea mays L.), durante o ciclo em dias apös emergência $\ldots \ldots \ldots \ldots \ldots \ldots \ldots$ 
14 - Produtividade Biolōgica (PB), média para o tratamento com subsolagem, nos diversos espaçamentos, em uma cultura de milho ( Zea mays L.), durante o ciclo em dias apōs

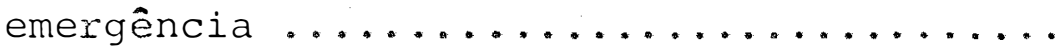

15 - Taxa de crescimento da cultura (TCC), para o tratamento convencional, nos diversos es paçamentos, em uma cultura de milho (Zea mays L.), durante o ciclo em dias após e-

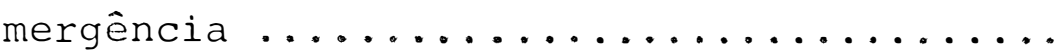

16 - Taxa de crescimento da cultura (TCC), para o tratamento com subsolagem, nos diversos espaçamentos, em uma cultura de milho (Zea mays. L.), durante o ciclo em dias apōs emergência $\ldots \ldots \ldots \ldots \ldots \ldots \ldots$

17 - Taxa de crescimento Relativo (TCR), para o tratamento convencional, nos diversos espaçamentos, em uma cultura de milho (Zea mays L.), durante o ciclo em dias apōs emergência $\ldots \ldots \ldots \ldots \ldots \ldots \ldots \ldots$

18 Taxa de Crescimento Relativo (TCR), para o tratamento com subsolagem, nos diversos es paçamentos, em uma cultura de milho (Zea 
niays...), durante o ciclo em dias apös e

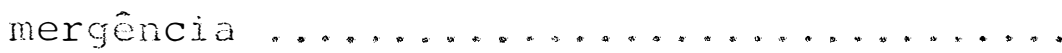

19 - Taxa de Assimilação Líquida (TAI $)$, para o tratamento convencional, nos diversos espaçamentos, em uma cultura de milho (Zea mays L.), durante o ciclo em dias após emergência $\ldots \ldots \ldots \ldots \ldots \ldots \ldots \ldots \ldots \ldots \ldots \ldots \ldots \ldots \ldots \ldots \ldots \ldots \ldots$

20 - Taxa de Assimilação Lĩguida (TAL), para o tratamento com subsolagem, nos diversos espaçamentos, em uma cultura de milho (Zea mays L.), durante o ciclo em dias após emergência $\ldots \ldots \ldots \ldots \ldots \ldots \ldots \ldots \ldots \ldots \ldots \ldots \ldots \ldots \ldots \ldots \ldots \ldots$

21 - Razóo de Area Foliar (RAF), para o tratamen to convencional, nos diversos espaçamentos, em uma cul tura de milho (zea mays L.), durante o ciclo em dìas apös emergência ......

22 - Razão de Årea Foliar (RAF), para o tratamen to com subsolagem, nos diversos espaçamentos, em uma cultura de milho (Zeamays I.), durante o ciclo em dias apös emergência ...... 
ANALISE QUANTITATIVA DO CRESCIMENTO DO CULTIVAR AG 401 (Zea mays I.), SOB DIFERENTES SISTEMAS DE PREPARO DO SOLO E POPULAÇÃO DE PLANTAS

Paulo Augusto Manfron

Paulo Leonel Libardi

orientador

\section{RESUMO}

O presente experimento foi conduzido no campus da Escola.Superior de Agricultura "Luiz de Queiroz", da Universidade de são Paulo, na cidade de Piracicaba, sP. o local situa-se a $580 \mathrm{~m}$ acima do nível do mar, numa latitude de $22^{\circ} 42^{\prime} 30^{\prime \prime S}$ e numa longitude de $47^{\circ} 38^{\prime} 00^{\prime \prime} \mathrm{W}$. O objetivo deste trabalho foi o de estudar o comportamento do cultivar de milho hibrido AGROCERES 401 num solo clasisificado como "Terra Roxa Estruturada", sob duas condiçöes de preparo do solo (convencional e subsolagem) e três espaçamentos entrelinhas $(0,70 ; 0,90$ e $1,10 \mathrm{~m})$, através da anälise quantita tiva de crescimento. A distribuição de rảzes no perfil de 
solo subsolado e não subsolado também foi estudada. De uma maneira geral, pôde-se concluir que: (i) nenhum dos trata mentos estudados teve influência nos estádios fenológicos da cultura; (ii) a produção de grãos foi maior para o espa Çamento de 1,10 m, em ambos os preparos do solo; (iii) não houve diferenças dos parâmetros fisiológicos em todosos trạ tamentos estudados, e (iv) houve um bom desenvolvimento radicular nos dois tratamentos de preparo do solo, mas mais profundo no perfil subsolado. 


\title{
QUANTITATIVE GROWTH ANALXSIS OF THE AG 401 (zea mays, L.) CORN VARIETY, UNDER DIFFERENT SOIL PREPARATIONS SYSTEMS AND DIFFERENT PLANT POPULATIONS
}

Paulo Augusto Manfron

\author{
Paulo Leonel Libardi \\ Adviser
}

\section{SUMMARY}

This work was carried out at the experimental

fields of the Escola Superior de Agricultura "Luiz de Queiroz", University of São Paulo, Piracicaba, SP, Brazil. The field site is $580 \mathrm{~m}$ above sea level, $20^{\circ} 42^{\prime} 30^{\prime \prime} \mathrm{S}$ and $47^{\circ} 38^{\prime} 00^{\prime \prime} \mathrm{W}$. The objective of the work was to study the behaviour of a corn variety (AGROCERES 401) that were grown on Terra Roxa Estruturada (Oxic Paleudalf) under two soil preparation conditions (conventional and subsoiled) and with the plants spaced at three different intervals $10.70,0.90$ and $1.10 \mathrm{~m})$; this was done by using the quantitative growth analysis. Besides, the root distribution along the soil 
profile was also studied. From the results it could be concluded that (i) none of the studied treatments had influence on the phenological stages of the corn crop; the grain yield was higher for the plant rows $1.10 \mathrm{~m}$ apart in both soil preparation treatments; (iii) there was no differences of the physiological parameters in all studied treatments, and (iv) there was a good root growth in both soil preparation treatments, but deeper in the subsoiled profile. 


\section{INTRODUÇÃO}

o milho é uma planta originária do continente americano que, pelas suas mültiplas utilizações, quer na alị mentação humana, quer na animal, ou ainda, como matéria prima na indústria, constitui-se num dos cereais mais cultivados no mundo.

No Brasil, o nỉvel de produtividade está muito abaixo do desejado, em comparação com outros países que u tilizam mais tecnologia, mas as perspectivas são de aumentos substanciais. Dentre as espécies de plantas cultivadas, o milho tem sido o mais pesquisado técnica e cientificamente, o que tem contribuido para um crescimento da sua produti vidade. De um modo geral, a produção de uma cultura está in timamente associada a uma série de fatores, tais como, ăgua, Iuz, temperatura, tipo de solo, caracteristicas da planta, sistemas de cultivo e manejo da planta durante o ciclo.

Vários pesquisadores têm estudado a influên- 
cia dos sistemas de cultivo e de densidade de plantas, präticas agronômicas importantes por afetarem a emergência, o desenvolvimento radicular, o acamamento de plantas, a resis tência à seca, a produção biológica e econômica. Entende-se por sistema de cultivo o preparo do solo, sendo que o mais difundido atualmente entre egricultores é o chamado sistema convencional, que consiste de uma aração e duas gradagens. Mas, formas alternativas de preparo do solo bastante conheci das por pesquisadores, como a subsolagem mais grade pesada, so mente a grade pesada, o cultivo mỉnimo e o plantio direto, tambēm tēm sido utilizadas em diferentes situações, para, per mitir uma melhora nas condições dos solos. A densidade dé plantas é outro aspecto importante a ser considerado porque está relacionada com a capacidade da cultura em aproveitar a energia solar e, portanto, com a produção econômica, assim como a biológica, uma vez que essas dependem da capacidade fotossintētica do vegetal.

Existe, na maioria dos casos, uma correlação positiva entre estas duas produções, pelo fato da planta ser uma integradora de estímulos e com isto permitir que a avaliação de sua produção primária seja realizada através da análise quantitativa do crescimento, a qual, além de forne cer ötimos resultados, requer informações que podem ser obti das sem a necessidade de equipamentos sofisticados. Tais informações são a massa de matëria seca total da planta e de suas partes (folhas, colmos, raizes, etc) e o tamanho do apa 
relho fotossintetizante (área foliar) obtidos a certos intervalos de tempo durante o ciclo da cultura. Os valores da massa de matéria seca e da área foliar, nos diferentes tempos, são utilizados posteriormente na estimativa de indices fisiológicos, tais como: Indice de Area Foliar (IAF), Produtividade Biológica (PB), Taxa de Crescimento da Cultura (TCC), Taxa de Crescimento Relativo (TCR), Taxa de Assimilação Liquida (TAL) e Razão de Area Foliar (RAF). Visando um conhecimento mais consistente sobre o uso da Análise Quantitativa de Crescimento e de sua problemática quanto a coleta e a aná lise de dados, bem como, estudar a resposta da comunidade de plantas de milho quanto a diferentes sistemas de preparo do solo e população de plantas devido a diversificação de resul tados encontrados na literatura.

O presente trabalho tem por objetivo (i) estu dar através da análise quantitativa de crescimento convencio nal, o comportamento de um cultivar de milho híbrido (AGROCERES 401), sob dois sistemas de preparo do solo (convencional e subsolagem) e três espaçamentos entre-linhas $\quad(0,70$, 0,90 e 1,10 mi, e (ii) determinar a distribuição quantitativa de raízes no perfil do solo subsolado e não subsolado. 


\section{REVISÃO DE LITERATURA}

Nesta revisão, hã quatro aspectos a serem discutidos pela importância e associação que prestam ao presen-: te estudo: efeitos ambientais no desenvolvimento do milho; influência do sistema de preparo do solo na produtividade do milho; densidade de plantas; e comportamento dos parâmetros Eisiológicos na cultura.

2.1. Efeitos ambientais no desenvolvimento do milho

A produtividade de uma cultura depende de uma série de interrelações complexas entre plantas individuais, comunidade de plantas e meio ambiente. Segundo WATSON (1952), o crescimento e o desenvolvimento da planta são fenômenos complexos, pois envolvem o efeito de fatores externos nos pro cessos fisiológicos, interrelações entre diferentes processos planta-ambiente e sua dependência dos fatores internos 
determinados pela constituição genética da planta. Muitos fatores externos como condições climáticas e do solo, princí palmente a radiação solar e a disponibilidade de água, influenciam a produtividade.

Um fator importante para o milho, responsável pelo aumento de produção, é a disponibilidade de água. A irrigação, segundo DOPPLER (1983), é a base do desenvolvimento, pois permite regular o fator água da produção. RHODES (1962) verificou a importância do modo de aplicação de āgua por irrigação e chegou à conclusão que o uso eficaz da irrigação permite produzir $140 \mathrm{~kg}$ de milho para cada $100 \mathrm{~m}^{3}$ dẹ água aplicada, e que com irrigação menos eficaz, se produz $50 \mathrm{~kg}$ de milho, portanto, uma diferença de $90 \mathrm{~kg}$ para cada $100 \mathrm{~m}^{3}$ de água aplicada. Segundo SWAN e HICKS (1972) e HILER et alii. (1974), vários pesquisadores têm detectado redução de 60\% no rendimento quando o déficit hídrico era simula do desde o estádio de floração até o enchimento de grãos, em comparação com reduções de 40 a $50 \%$ para plantas que sofreram déficit hídrico durante a iniciação floral e durante o enchimento de grãos, respectivamente. ESPINOZA et alii (1980) concluiu que a partir do dēcimo dia sem chuva ou irri gação, próximo ao período de floração, a redução do rendimen to do milho pôde ser estimada em $100 \mathrm{~kg} / \mathrm{ha} / \mathrm{dia}$, aproximada mente, e que a redução causada por déficit hídrico induzido na ëpoca seca, no estádio meprodutivo da cúltura, atingiu a cifra de 40 a $60 \%$ em relação aos tratamentos em que não fal- 
tou âgua. Na região do cerrado, ESPINOZA (1982), pesquisou a resposta de 12 cultivares de milho ao déficit hídrico em condições de campo, e verificou que as médias dos rendimentos sob irrigação permanente e em condições de déficit hỉari co, foram, respectivamente, de 4557 e $3192 \mathrm{~kg} / \mathrm{ha}$ e que não houve efeitos significativos do regime hidrico nos cultivares quanto ao nümero de espigas ou ao seu peso. Quanto ao efeito negativo do déficit hídrico, MCPHERSON e BOYER (1977) verificaram que este seria devido a reduções no processo de translocação e principalmente na taxa de fotossíntese.

Naquelas regiiões onde a prätica da irrigação não tenha sido difundida ou mesmo não exista possibilidade para tal, o regime pluviométrico é o elemento fundamental pa ra que não aconteça déficit hídrico em periodos críticos para a cultura. Segundo CANECHIO FILHO e ALMEIDA (1973), as regiões onde a precipitação varia de 250 a $5000 \mathrm{~mm}$ anuais, possibilitam a instalação da cultura do milho, sendo que um minimo de $200 \mathrm{~mm}$, durante o verão, bem distribuídos, são ne cessários para uma produção sem irrigação.

Outro fator ambiental a ser discutido é a radiação solar, isto porque ela é a fonte de energia para todos os processos biológicos existentes na superfície terrestre. LOOMIS e WILLIAMS (1963) estimaram o potencial de produtividade das culturas, baseado na quantidade total de ener gia solar que pode ser utilizada pelas plantas no processo 
fotossintético, considerando perdas de albedo, absorção inativa e respiração. Para uma superfície que recebe $500 \mathrm{cal} /$ $\mathrm{cm}^{2} /$ dia de radiação solar, no estágio vegetativo, a estimatị va é de uma produção de massa de matéria seca de $71 \mathrm{~g} / \mathrm{m}^{2}$ de superficie cultivada por dia. Se a contribuição dos constituintes inorgânicos consiste em 8 \% da massa de matéria seca, o potencial de produtividade será então de $77 \mathrm{~g} / \mathrm{m}^{2} / \mathrm{dia}$, o que corresponde a $770 \mathrm{~kg} / \mathrm{ha} / \mathrm{dia}$. O auto-sombreamento das fo lhas e mesmo estruturas não fotossintetizadoras, como as paniculas do milho, podem representar um fator de diminuição da quantidade de radiação disponivel para a fotossíntese, que segundo DUNCAN et alii (1967), numa população de 50000 plan: tas/ha, atinge o porcentual de interceptação de 9\% da radiação solar global que chega ao topo do dossel de plantas.

MOSS et alii (1961) mostraram que 90\% das flü tuações horărias na fotossintese líquida, em uma população de milho, podem ser explicadas pelas flutuações de luz, isto veio a ser confirmado por LOOMIS e WILLIAMS (1963), segundo os quais a eficiência na utilização de luz pela superficie da cultura de milho será maior com luz contínua, com baixa ou alta intensidade, do que com luz flutuante causada pela nebulosidade. Entretanto, pode ser esperada uma relação estreita entre total de radiação solar e a produção de uma cul tura densa, com pequena perda de luz. BAKER e MUSGRAVE (1964) verificaram, em condições de campo, que uma população 
de plantas de milho em concentrações normais de $\mathrm{CO}_{2}$ e índice de área foliar maior do que 6 dificilmente alcançará o ponto de saturação de luz e, por conseguinte, o limite máximo de fotossintese.

2.2. Influéncia do sistema de preparo do solo na produtividade do milho

A cultura do milho se ressente muito da falta de aeração causada por uma drenagem insuficiente, por istö deve ser destinado ao milho, preferivelmente, solos férteis, profundos, soltos e de boa permeabilidade à água e ao ar. A compactação do solo, segundo TAYLOR et alii (1964) e BEZERRA DE OIIVEIRA (1967), impede o desenvolvimento das raízes, de modo que o espaço poroso do solo por eles explorado é pequeno, provocando uma ábsorção deficiente de nutrientes pela cul tura (WIERSUM, 1961; PRIMAVESI, 1964; PRIMAVESI e PRIMAVESI; 1966; PERIGAUD, 1965). Considerando que os sistemas de manejo do solo poderão alterar a geometria dos poros, influenci ando a sua estrutura, inümeros pesquisadores têm estudado mé todos alternativos de prepado do solo como (a) cultivo mínimo e plantio direto (PRIMAVESI e PRIMAVESI, 1971; ORTOLANI et alii, 1981); (b) enxada rotativa (PRIMAVESI e PRIMAVESI, 1971; ORTOLANI et alii, 1981); (c) subsolagem (SILVA, 1973a, 
b, citado por VIEGAS, 1980; ORTOLANI et alii, 1981); e

o preparo convencional, que consiste de aração e gradagem (SA LEITE, 1959; ALOISI SOBRINHO e ARRUDA, 1960; MARQUES e BERTO NI, 1961; BENEZ et alii, 1979; ORTOLANI et alii, 1981). Por tanto, se reveste de suma importāncia para este trabalho, descrever dados obtidos por pesquisadores brasileiros nas nossas condições de clima e solo.

Em 1959, SÅ LEITE, estudando diferentes siste mas de preparo do solo para a semeadura do milho, no Estado do Rio Grande do Sul, verificou uma pequena mas constante vantagem de uma sobre duas arações. E que a aração profunda, além de mais dispendiosa, não se mostrou superior àquela de profundidade normal de $30-35 \mathrm{~cm}$, dados estes semelhantes aos obtidos por PRIMAVESI e PRIMAVESI (1971), que observaram um aumento no rendimento com a utilização de aração superficial, em relação à aração profunda e a não-aração. Também ALOISI SOBRINHO e ARRUDA (1960) e MARQUES E BERTONI procuraram avaliar a produção do milho através dos sistemas de preparo do solo, com arações e gradagens. ALOISI SOBRINHO e ARRUDA (1960) trabalharam o solo com aração e gradagem complementar, em comparạão com o preparo à enxada, para evi $\operatorname{tar}$ a desagregação do solo. A diferença foi altamente signi ficativa a favor do preparo mecânico, correspondendo a um ren dimento de $2267 \mathrm{~kg} / \mathrm{ha}$ para o preparo mecānico e $1746 \mathrm{~kg} / \mathrm{ha}$ para o superficial. MARQUES e BERTONI (1961), durante sete 
anos consecutivos, estudaram estes sistemas e verificaram que o uso do arado comum proporciona produções mais altas do que as obtidas com outros sistemas, inclusive com o arado de superficie. En solo de estrutura mais compacta, duas arações apresentam Iigeira vantagem lcerca de $4 \%$ de aumento na produ ção). Em área mais infestada de ervas daninhas verificaram também aumento da ordem de $13 \%$ na produção, com duas arações. Em solo de estrutura mais solta, apenas uma aração é suficiente. O efeito induzido pela roda do trator na população de plantas, devido às várias passagens para arações e gradagens, foi estudado por BENEZ et alii (1979). Os resultados obtidos revelam que, em solo arenoso, a compactação induzida pe: la roda do trator foi benéfica na obtenção de boas populações de plantas na época da colheita, somente para o preparo do solo com uma aração, sendo prejudicial para uma aração e uma gradagem, duas arações e uma gradagem, uma aração e uma gradagem e uma aração e duas gradagens.

\section{Mais recentemente, SILVA et alii (1973 a,b),}

citado por VIEGAS (1980), observaram que a subsolagem em com paração com o emprego dos arados de discos e aiveca, na produção do milho, não favorece, cheganđo a prejudicar em $25 \%$ a produção. As produções médias foram de 4408,$0 ; 4590,0$ e $5839,0 \mathrm{~kg} / \mathrm{ha}$, para subsolagem, arado de discós e arado de aiveca, respectivamente. Ao analisar o efeito da profundida de da subsolagem, verificaram que, os resultados não foram 
compensadores, principalmente devido ao custo desta operaÇão. ORTOLANI et alii (1981), avaliando a resistência do mi lho ao acamamento, em diferentes preparos do solo, como convencional (aração e gradagem), subsolagem mais grade pesada, somente grade pesada, plantio direto e enxada rotativa, pude ram concluir que os diferentes sistemas de preparo do solo não influíram nos caracteres resistência mecânica do colmo e porcentagem de plantas quebradas, o mesmo não ocorrendo com os caracteres diâmetro do colmo e produção de grãos, para os quais os sistemas convencional e enxada rotativa mostraram-se superiores aos demais.

Muito provavelmente, os diferentes sistemas de preparo do solo influem na profundidade do sistema radicu lar e no tipo de ramificações àas raízes. Isto se reveste de grande importância, devido a serem estas raizes os elemen tos que melhor respondem pelas diferenças do grau de tolerância à seca das plantas cultivadas. Portanto, existe uma íntima associação entre o crescimento das raízes e o das partes aéreas, sendo que a relação parte aérea/sistema radicu$\operatorname{lar}(A / R)$ varia com os fatores ambientais e também nas várias fases do crescimento das plantas. FOTH (1962) constatou que ocorre mudanças consideráveis na taxa de crescimento da parte aérea como da parte radicular, durante o período de crescimento do milho, e que o desenvolvimento dos grãos acon teceu principalmente logo que o crescimento radicular cessou, 
o que foi associado a um aumento da relação parte aérea/sistema radicular. Esta afirmativa é comprovada por HENGEL e BARBER (1974) que, estudando o desenvolvimento e distribuição do sistema radicular do milho em condições de campo, verificaram que a máxima densidade de raizes foi de $4,1 \mathrm{~cm} / \mathrm{cm}^{3}$, na camada de 0-15 cm de profundidade, aos 79 dias. A massa e o comprimento de raízes frescas tiveram um incremento até 80 dias apös o plantio, mantiveram-se constantes por uns 14 dias, e depois decresceram rapidamente no estádio reprodutivo da planta. A produção de grão obtida foi de $6160 \mathrm{~kg} / \mathrm{ha}$ em 1970 e $11700 \mathrm{~kg} / \mathrm{ha}$ em 1971. GERARD et alii (1982) afirmaram que a compactação è o fator mais importante de influên cia no crescimento de raízes e produtividade de culturas, de vido influenciar numa propriedade fundamental do solo chamada porosidade. CRUZ e TAMES (1972), estudando a distribuição do sistema radicular de um cultivar de milho híbrido de ciclo curto, em cultivo irrigado em um solo franco, verifica ram que mais de 608 da massa total de raízes das amostras en contrava-se nos $20 \mathrm{~cm}$ superficiais do solo, e depois da poli nização, quando praticamente cessa o crescimento radicular, a máxima penetração alcançada pelas raízes foi ligeiramente inferior a um metro.

Estes resultados são confirmados por ESPINOZA (1982), que estudou a distribuição de raízes dos cultivares Cargill 111, AG 259 e AG 401, em um Latossolo Vermelho-Escu- 
ro (Typic Haplustox) de cerrado do Distrito Federal. Os dados obtidos por este pesquisador indicaram que não houve diferença entre os cultivares quanto à densidade radicular para as diferentes profundidades do solo, quando submetidas ou não ao déficit hídrico. E a distribuição, em massa, de raízes mostrou uma concentração de 60 a $80 \%$ nas primeiras camadas do perfil do solo, e a partir dos $40 \mathrm{~cm}$, a percentagem de distribuição diminuiu atē 10-15\%.

\subsection{Densidade de plantas}

Para determinada condição de solo, clima, cul tivar e tratos culturais, existe um nümero de plantas por unidade de área que conduz a mais alta produção. Considera-se como limite, o nümero máximo de pläntas que não concorram entre si por nutrientes, ägua e luz. Portanto, locais onde o solo é mais fértil e não esteja sujeito à seca, comportam maior nümero de plantas. Quando se modifica o espaça mento entre-linhas e/ou população de plantas, o estudo da produção se torna muito complexo, devido ao fato de surgir as mais variadas reações por parte da comunidade de plantas. Isto tem levado ao surgimento de inúmeros trabalhos no mundo inteiro, sobre a quantificação dos efeitos da modificação da população de plantas, entre os quais podem-se citar: TANNER 
et alii (1960), YAO e SHAW (1964), DALE e SHAW (1965), ALESSI e POWER (1974, 1975), ALVIM e ALVIM (1969), GALVÃO et alii (1969), RUMAWAS et alii (1971), WINKLER (1972), LEITE e PATERNIANI (1973), GALVÃO e PATERNIANI (1975), CHING CHOY et alii (1977), MOLL e KAMPRATH (1977), MUDSTOCK (1978) e MACHA Do et alis (1982).

Segundo GALVÃO et alii (1969) que estudaram o efeito da população de plantas e dos niveis de nitrogênio so bre a produção em dois ensaios realizados em Viçosa, Minas Gerais, sendo o primeiro com populações de $40,50,60$ e 70 mil plantas por hectare; e o segundo com populações de 30 ; 40,50 e 60 mil plantas por hectare. As maiores produções foram obtidas com populações variando de 40 a 60 mil plantas por hectare. A população ótima de plantas para grãos e forragem é da ordem de 30000 e 40000 plantas por hectare, segun do ALESSI e POWER (1974). Contudo, GALVÃO e PATERNIANI (1975) verificaram que mesmo nas densidades atualmente recomendadas, 40000 e 50000 plantas por hectare, que são populações moderadas, quando se aplicam adubações adequadas, observa-se, com frequência, elevado grau de acamamento e quebra de plantas, prejudicando a produção e tornando desaconselhável a colheita mecânica.

Em Itabuna, Bahia, ALVIM e ALVIM (1969) deter minaram em ambiente tropical a eficiência da conversão da energia luminosa do milho e do feijão quando plantados em dí 
ferentes densidades. Verificaram que tanto a massa de matéria seca como a área foliar por planta diminuíram com o aumento de densidade de plantio e que a consorciação de culturas, em todas as densidades, ocasionou decréscimo na produção de matéria seca e área foliar por planta no caso do feijão e aumento no caso do milho. Já RUMAWAS et alii estudaram o desenvolvimento e produtividade de um milho hibrido, em uma população de 44000 plantas por hectare, com es paçamento de 50 e $75 \mathrm{~cm}$ entre-linhas. Verificaram que a por centagem de carboidratos das plantas adultas em espaçamentos de 50 e $75 \mathrm{~cm}$ entre-linhas, foram similares e também a produ. tividade não apresentou diferenças estatisticamente significativas. Resultados semelhantes aos obtidos por WINKLER (1972), que mantendo a população em 60000 plantas por hectare, e mudando o sistema de espaçamento $(1,00 \times 0,25$ e 0,5 x $0,5 \mathrm{~m})$ não verificou diferenças significativas quanto à produção. Entretanto, LEITE e PATERNIANI (1973) analisaram o comportamento do milho braquítico em duas diferentes densida des de plantio $(1,00$ e 0,75 m entre-linhas) e três populações: 40, 80 e 120 mil plantas por hectare. Chegaram à conclusão que diminuindo o espaçamento entre-linhas, mas manten do a mesma população entre-plantas, houve aumento da produção, da massa média da espiga e da grossura do colmo. No Rio Grande do Sul, MUDSTOCK (1978), estudando um híbrido precoce em diversos espaçamentos entre-linhas, procurou determinar a reação deste a sua interação com o número de plantas por uni 
dade de área, testando qual a fase do desenvolvimento seria mais afetada pelos diferentes arranjos das plantas no solo. No primeiro ano não houve efeito do espaçamento entre-linhas no rendimento de grãos em razão da forte deficiência híarica que ocorreu no período de polinização. No segundo aro, as linhas com afastamento de $50 \mathrm{~cm}$ foram superiores em rendimen to de grãos às linhas com 80 a $110 \mathrm{~cm}$ apenas nas populações de 70000 e 90000 plantas por hectare. Em baixas populações a disposição das plantas não afetou nenhuma das caracterís ticas estudadas.

Em muitos estudos relacionados com o efeito da densidade de plantio, o fornecimento da água tem sido geralmente suficiente para satisfazer as necessidades da cultu彑 ra. Consequentemente, a teoria de que uma elevada população aumenta a produtividade, devido à maior exposição à radiação solar e $\mathrm{CO}_{2}$, pode não ser aplicada em regiões onde a água po de limitar os rendimentos das culturas. Contudo, DALE e SHAW (1965) não observaram efeito da densidade de plantio de 20000 até 40000 plantas por hectare, sobre o rendimento do milho, em condições de déficit hídrico induzido. ALESSI e POWER (1975) mencionaram que na região Centro-Oeste dos Estados Unidos, sob condições semi-áridas, os melhores rendimentos fo ram obtidos com plantios de 30000 até 40000 plantas por hectare. O maior espaçamento originou espigas de maior peso e em maior número por planta. MOLL e KAMPRATH (1977) afirmam 
que, sob condições em que a água do solo não é um fator limi tante, um aumento na densidade de plantio, até 50000 plantas por hectare, resulta em maiores rendimentos por hectare. TAN NER et alii (1960), postularam que elevadas populações de miTho apresentariam uma evapotranspiração (ET) mais elevada do que as baixas populações, o que seria devido à diferença na magnitude do componente transpiração da ET, embora YAO e SHAW (1964) tenham encontrado que as maiores densidades de plantio apresentam ET mais baixa, por ser menor a radiação líquida que penetra na vegetação. Segundo CHING CHOY et alii (1977), a literatura parece indicar que no caso de muitas cul turas com plantios em espaçamentos estreitos se obtém um som breamento mais completo do solo, reduzindo, assim, a radiação líquida que chega a todas as folhas da planta. Tal fato gera uma ET que pode ser menor que aquela apresentada pela mesma cultura, quando em menor densidade de plantio. Mais recentemente, MACHADO et alii (1982), testando os cultivares de milho Erecta Dente, Erecta Flint, Normal Dente e Normal Flint, verificaram que a variação na densidade de plantio acarretou alterações morfológicas e fisiológicas nas plantas, sem, no entanto, alterar a distribuição relativa de matéria seca entre os diversos órgãos componentes da planta. 
2.4. Comportamento dos parâmetros fisiológicos na cultura

Ao analisar uma curva de crescimento de um ve getal em termos de massa da matéria seca ou altura do caule, observa-se que existem diferentes fases: um periodo inicial mais lento, seguido de uma fase de rápico aumento e finalmen te um decréscimo na acumulação da matéria seca, ou na altura da planta. No início, a planta depende de reservas da semen te para a produção dos órgãos que compõem a plântula. Após o desenvolvimento do sistema radicular e a emergência das fo lhas, os processos anabólicos, dependentes da fotossintese, se traduzem por um rápido crescimento. Atingindo o tamanho definitivo, a planta inicia uma fase de senescência, que se reflete, inicialmente, na paralisação da produção de matéria orgânica (MAGALHÃES, 1979). O crescimento de uma planta pode ser medido obtendo-se sua altura, mas através da utilização da análise quantitativa de crescimento, obtêm-se dados mais precisos e um número muito maior de informações. Segun do MAGALHÃes (1979), é um método que descreve as condições morfofisiológicas da planta em diferentes intervalos de tempo, entre duas amostragens sucessivas, e se propõe acompanhar a dinâmica da produção fotossintética avaliada através da acumulação de matéria seca. As técnicas de análise de crescimento foram desenvolvidas há mais de 60 anos pelos fisiologistas vegetais BLACKMAN (1919), BRIGS et alii (1920) e, mais recentemente, por BLACKMAN (1968), e é considerada in- 
ternacionalmente como método padrão para se obter a estimati va do rendimento biológico das comunidades vegetais. A formulação, o significado e a análise dos índices fisiológicos estão descritos em diversos textos, por exemplo, MONTGOMERY (1911), BRIGGS et alii (1920), FISHER (1921), GREGORY (1926), WATSON (1952, 1958), RADFORD (1967), RICHARDS (1969), KVET et alii (1971), EAGLES $(1971 \mathrm{a}, \mathrm{b})$, EVANS $(1972)$, WALLACE et alii (1972), DUNCAN (1975), HUNT (1978), MAGALHÃES (1979) e REIS e MULLER (1979).

Mais especificamente, a anälise quantitativa do crescimento para a cultura do milho tem sido utilizada por vários pesquisadores, podendo-se citar, dentre outros, ALLISON $(1964 a, b)$, WILLIANS et alii $(1965 a, b)$, ALVIM e ALVIM (1969), LOPES e MAESTRI (1973), SILVA et alii (1974), LOPES e LOPES (1977), ROSSIELLO et alii (1981) e MACHADO et alii (1982). Deve-se salientar que o principal parâmetro mensurá vel é indiscutivelmente a áxea foliar desenvolvida pelo vege tal (WATSON, 1952) e, em menor grau, a taxa de assimilação Iíquida (TAL) e a taxa de crescimento relativo (TCR), apesar de serem estes últimos muito variáveis com a idade da planta e a densidade de cultivo, merecendo por isto a restrição de muitos. Segundo WATSON (1952) e ALLISON (1964a), de um modo geral, a área foliar é o elemento mais importante, devido às variações na produção de matéria seca estarem associadas, prin cipalmente, com a variação da área foliar. A soma das áreas 
de todas as folhas, dividida pela unidade de área do solo, constitui, segundo WATSON (1952), o que se chama de índice de área foliar (IAF), elemento que pode ser tomado como medi da do sistema fotossintético. Segundo ALLISON (1964b), a eficiência fotossintética em milho apresenta um decréscimo substancial do topo para a base das folhas da planta, eviden temente como resultado do decréscimo do suprimento de luz e provavelmente também pelo aumento da idade das folhas. Veri ficou-se também que as lâminas e bainhas das folhas contribuem com quatro quintos e um quinto na produção de matéria seca, respectivamente, em relação às suas respectivas áreas.

A medida que aumenta o indice de área foliar (IAF), a absorção de luz e a taxa de produção de matéria seca também aumentam, embora muitos dados indiquem que o indice de área foliar ótimo varia com a cultivar e com a estação do ano (LOOMIS e WILLIAMS, 1963). Entretanto, WILLIAMS et alii (1965a e b), demonstraram que a eficiência de conversão da energia solar é de apenas $1 \%$, significando uma perda quase total da radiação solar que chega à superfície terrestre. WATSON (1956) constatou que a fotossintese realizada pela fo Iha não é o ünico fator determinante na produção de grãos, pois este processo, nas espigas de trigo, produz cerca de um terço da matéria seca dos grãos, sendo que os pedúnculos e bainhas das folhas também contribuem para o enchimento dos grãos. ALLISON (1964a) e MONTEITH (1969) definiram que a ta 
xa de produção de matéria seca para uma cultura pode ser expressa como o produto da área foliar pela taxa de assimilação líquida. Existe, entretanto, uma relação inversa entre - indice de área foliar e a taxa de assimilação líquida; nos valores mais elevados do indice de área foliar, causam mútuo sombreamento das folhas. Portanto, um aumento na área foliar não aumenta necessariamente a produção de matéria seca em culturas bem adubadas e irrigadas. CHANG (1968) constatou que, após o florescimento, a assimilação líquida cai brus camente em razão da senescência das folhas, fator este que levou WATSON (1956) a sugerir que a produção de grãos pode ser aumentada se mantiver a área foliar em alto nível por mais tempo. Em muitas culturas anuais, onde as populações de plantas permitem rápido desenvolvimento com alto índice de área foliar, podem resultar baixa produção e má qualidade do produto (LOOMIS e WILLIAMS, 1963). Já, ENGLEDOw e WADHAM (1923), citados por MEDEIROS e SCHLEHUBER (1971) estudaram a produção e seus componentes em cereais, isto é, o número de plantas por unidade de área, o número de espigas por plantas, o número de grãos por espiga e a massa de grãos. Eles tenta ram, através de um sistema de sintese de hibridação, acumular numa planta uma combinação ótima dos componentes da produção. WATSON (1952) determinou que tais estudos não definiam os caracteres que controlam a produção. STOSKOPF e REINBERGS (1966) fizeram uma severa critica aos chamados com ponentes da produção, afirmando que eles não determınam a 
produção, pois são a própria produção. BONNER e GALSTON (1955) ressaltaram que no crescimento das plantas e de suas partes, além de substâncias minerais, absorvidas pelas raízes e hidratos de carbono, sintetizados nas folhas, existe a influência de substâncias químicas especiais, os fitohormônios, que determinam a correlação entre as partes da planta em crescimento.

No Brasil, ALVIM e ALVIM (1969) estudaram

efeito da densidade de plantio no aproveitamento da energia luminosa pelo milho (Zea mays L.) e pelo feijão (Phaseolus vulgaris L.), em culturas exclusivas e consorciadas. Obtive ram que a taxa de produção de matéria seca aumentou na proporção direta com a densidade de plantas, atingindo o valor máximo de $57,7 \mathrm{~g} \cdot \mathrm{m}^{-2} \cdot \mathrm{dia}^{-1}$, com o milho na densidade de 100 plantas $/ \mathrm{m}^{2}$, correspondendo a uma eficiência de conversão de energia luminosa de $10,5 \%$ durante o primeiro mês de cultivo. O Indice de Area Foliar variou para o milho, de 2,8 a 21,7 na cultura exclusiva e de 1,4 a 11,0 na consorciada, ultrapassando, nas maiores densidades de plantio, a média deste indice em cultivos tradicionais de milho, que varia de 4,0 a 5,0. Também, LOPES e MAESTRI (1973) analisaram o crescimento e a conversão da energia solar em populações de milho. As conclusões que chegaram estes pesquisadores foram que a produção biológica foi maior para as populações mais densas, en quanto que a produção econômica não diferiu estatisticamente nas três populações $\left(4,6\right.$ e 8 plantas $\left./ \mathrm{m}^{2}\right)$. Os indices de á- 
rea foliar máximos foram de $4,4,5,8$ e 6,8 em ordem crescen te de populações, atingidos em torno do 929 dia após emergēn cia. A taxa de assimilação líquida apresentou a tendência de menores densidades darem valores superiores. A taxa de cres cimento relativo apresentou valores iniciais altos, decrescendo rapidamente até o 40 o dia após a emergência, quando as curvas das três densidades se confundem, tendência esta simi lar à razão de área foliar. A eficiência de conversão da energia solar mostrou curvas irregulares, com valores máximos de $2,9,3,4$ e $3,6 \%$, respectivamente, para as densidades de 4,6 e 8 plantas $/ \mathrm{m}^{2}$, no inicio do pendoamento. Na Estação Experimental Central do Instituto Agronômico de Campinas, Es tado de São Paulo, SILVA et alii (1974) estudaram o efeito da densidade de população e da conversão da energia solar em dois híbridos simples de milho, o HS 1227, do tipo duro, e HS 7777, de endosperma dentado. Verificaram que, apesar de não ter sido detectada diferença no Indice de Area Foliar dos híbridos, os parâmetros Produtividade Biológica, Taxa de Crescimento da Cultura e Eficiência Fotossintética mostraram ser afetados por genótipos na fase de maturação. o Indice de Área Foliar no plantio menos denso se estabilizou aos 48 dias após a emergência, fase correspondente à elongação do colmo. Na população mais densa, tal tendência ocorreu aos 65 dias, na fase do florescimento. O efeito da densidade de população foi altamente significativo sobre o Indice de área foliar na fase do florescimento, que passou de 3,46 a 6,08 
quando o número de plantas foi duplicado. Esse aumento de 768 indica que o espaçamento parece ser um dos componentes mais importantes para explicar o aumento do índice de área foliar. Na fase de elongação do colmo, a produtividade bioIógica passou de 138 a $354 \mathrm{~g} \cdot \mathrm{m}^{-2}$, correspondendo a um aumento máximo de $155 \%$ com relação à produtividade biológica obti da aos 36 dias. A taxa de assimilação líquida apresentou va lor médio de $0,050 \mathrm{~g} \cdot \mathrm{dm}^{-2} \cdot \mathrm{dia}^{-1}$, enquanto a taxa de crescimento relativo foi de $0,118 \mathrm{~g} \cdot \mathrm{g}^{-1} \cdot \mathrm{dia}^{-1}$. A eficiência de conversão de energia solar foi cerca de $8 \%$, correspondente a um indice de área foliar em torno de 6,3. LOPES e LOPES (1977) analisaram o crescimento e a conversão da energia solar em população de milho, em Pelotas, RS, no ano agricola de 1974/75. Verificaram que a matéria seca total máxima de $1256,4 \mathrm{~g} \cdot \mathrm{m}^{-2}$ foi atingida aos 121 dias após emergência. O va lor médio do indice de ârea foliar dos dois híbridos (AGROCERES 196 e SAVE 231) atingiu o valor máximo de 2,9 aos 104 dias após emergência, correspondendo à fase do espigamento. A taxa de produção de matéria seca dos híbridos não acompa nhou os indices de área foliar, pois o valor máximo obtido, no $689 \mathrm{dia}$, foi de $18,2 \mathrm{~g} \cdot \mathrm{m}^{-2} \cdot \mathrm{dia}^{-1}$, não coincidindo com o máximo indice de área foliar encontrado. A taxa de assimila ção líquida apresentou valores inicialmente altos, para assu mir valores negativos no final do ciclo dos híbridos. A efi ciência de conversão da energia solar, cujo valor máximo foi de 2,3\%, ocorreu aos 60 dias da emergência, na média dos dois 


\section{híbridos.}

MACHADO et alii, (1982) analisaram quatro variedades de milho em três densidades, através de funções matemáticas ajustadas. Obtiveram dados em que a análise da variância revelou não haver diferença significativa entre as quatro variedades e a inexistência de interação com a densidade de plantio. Os rendimentos biológicos foram de 1754 , 1479 e $1136 \mathrm{~g} \cdot \mathrm{m}^{-2}$, para as densidades de $66,6,50,0$ e 33,3 plantas $/ m^{2}$, correspondentes aos espaçamentos de $0,75,1,00$ e $1,50 \mathrm{~m}$ entre-linhas. Na ordem decrescente da densidade de plantas, a taxa de crescimento da cultura (TCC) atingiu valo res máximos de 35,30 e $24 \mathrm{~g} \cdot \mathrm{m}^{-2} \cdot \mathrm{dia}^{-1}$. A taxa de crescimen to da cultura, inicialmente foi pequena aumentando rapidamen te até atingir o máximo por ocasião do florescimento, e dimi nuindo posteriormente até a maturação. A taxa de crescimento relativo (TCR) foi elevada no início do ciclo, decaindo continuamente até a maturação. A razão de área foliar (RAF) apresentou um máximo ao redor de 30 dias após emergência, de caindo posteriormente. A máxima razão de área foliar (RAF) acarretou a mínima taxa de assimilação líquida (TAL) no mesmo período. Os efeitos do secamento progressivo do solo sobre o conteúdo hídrico relativo, a área foliar, a taxa de crescimento relativo, a taxa de assimilação líquida e o nivel de carboidratos solúveis em milho foram estudados em con dições de casa de vegetação por ROSSIELlo et alii (1981). Es tes pesquisadores verificaram que a deficiência hídrica ten- 
deu a reduzir mais a acumulação de matéria seca na parte aérea do que nas raizes, 36,4 e 12,6\%, respectivamente de redução com respeito aos controles, no final do periodo. Os efei tos sobre a área foliar dentro do grupo irrigado somente se manifestaram a partir do terceiro dia, devido a um abaixamen to da ordem de 6 a $7 \%$ no conteúdo hidrico relativo nos primeiros dias, suficientes para suprimir a expansão foliar nes tas plantas. Dentro do grupo não irrigado, a tendência da área foliar foi para diminuição. No último dia, a diferença com respeito ao controle diário foi de $37 \%$. A análise de re gressão mostrou que a taxa de assimilação líquida declinou linearmente com a diminuição de hidratação foliar. Sob condicões de secamento progressivo do solo, a taxa de crescimen to relativo declinou de forma contínua, refletindo os efeitos diretos da deficiência hídrica sobre a área foliar e a assimilação líquida. Quando as taxas de crescimento não são ótimas, os carboidratos solúveis tendem a se acumular e são usados como fontes de energia para o crescimento posterior, quando as folhas se reidratam.

Em resumo, de todos os fatores externos citados nesta revisão e que envolvem o crescimento e desenvolvimento de uma planta em uma região tropical, o que parece influir mais sobre o potencial reprodutivo, é o fator água. A sua distribuição irregular durante o ciclo da cultura permite que ocorra muitas vezes deficiências híaricas em periodos críticos como floração e estádio reprodutivo no caso do mi- 
1ho. Outros fatores como temperatura, preparo do solo e manejo de plantas, proporcionam uma melhor condição para que a planta possa exibir todo o seu potencial genético quanto a produção, permitindo com isto um máximo de aproveitamento. 


\section{MATERIAL E METODOS}

\subsection{Localização da ārea experimental}

A área experimental onde foi conduzido este ex perimento, localiza-se dentro do campus da Escola Superior de Agricultura "Luiz de Queiroz" (ESALQ), da Universidade de São Paulo (USP), na cidade de Piracicaba, SP. O local situa-se a $100 \mathrm{~m}$ do Posto Agrometeorológico do Departamento de Física e Meteorologia e encontra-se a $580 \mathrm{~m}$ acima do nível do mar, numa latitude de $22^{\circ} 42^{\prime} 30^{\prime \prime S}$ e numa longitude de $47^{\circ} 38^{\prime} 00^{\prime \prime} \mathrm{W}$.

\subsection{Caracterização da área experimental}

o local possui relevo ondulado, mas a ärea experimental era praticamente plana, com declividade em torno de $6 \%$ no sentio norte-sul (Figura 1). Muitas culturas foram pesquisadas anteriormente nessa área, sendo as princi- 


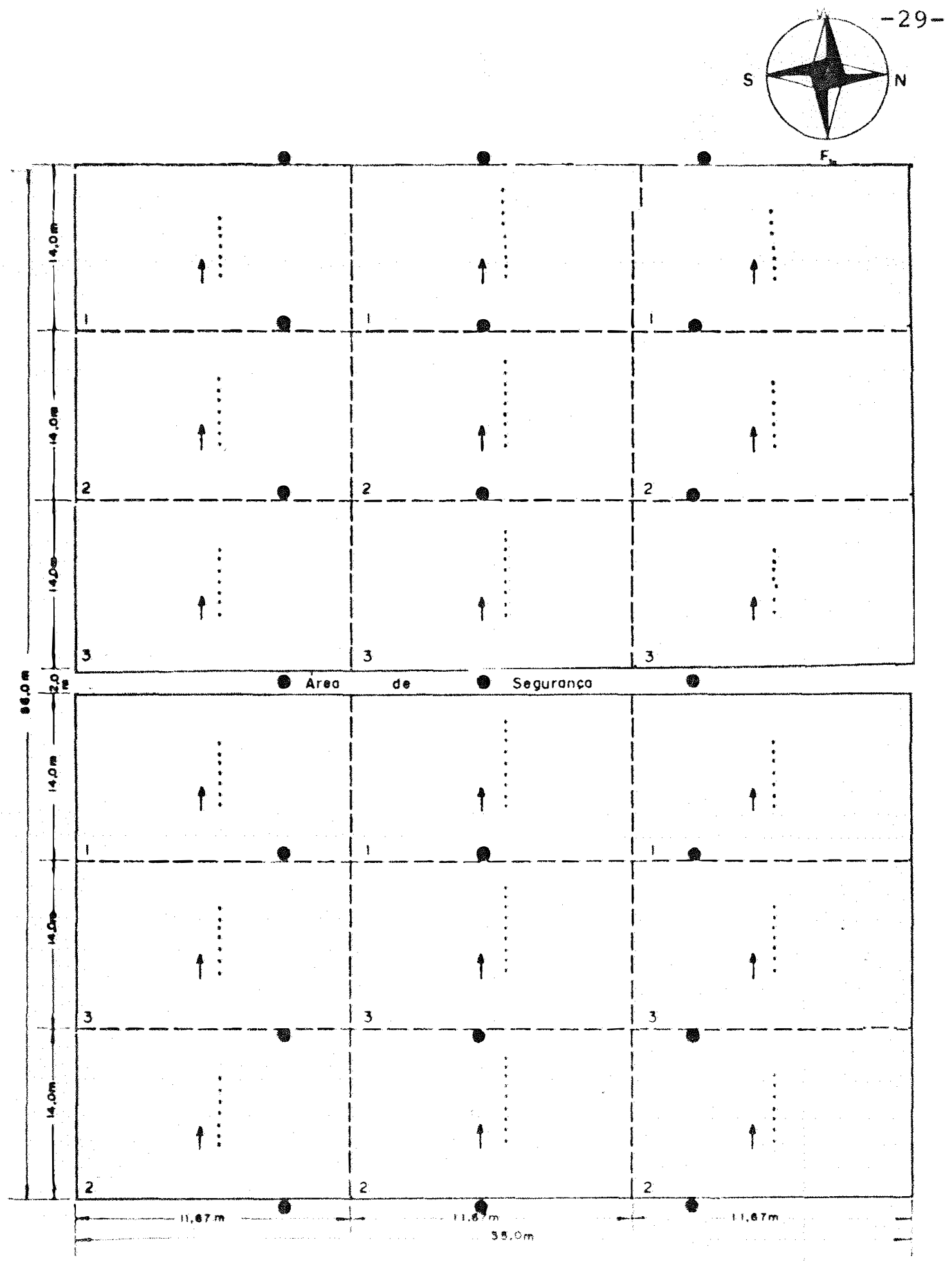

FIGURA 1 - Dimensões da ārea experimental, sob dois sistemas de preparo do solo: convencional (superior) e can subsolagm (inferior). Distribuição dos tensiômetros (. ) na ordem crescente ( $\uparrow$ ) de profundidades $(15,30,45,60,75,90,105,15$ e $195 \mathrm{~cm})$. Es paçamentos entre-linhas de 0,70 (1), 0,90 (2) e 1,10 m (3) e distribuição dos aspersores ( ) para irrigação durante o ci clo do milho (Zea mays L.). 
pais: as pastagens, o café, o milho, a cana-de-açúcar, o arroz de sequeiro e, mais recentemente, o feijão.

\subsubsection{Dimensões da área experimental.}

A ärea experimental tem um total de $3325 \mathrm{~m}^{2}$, com 2939,2 $\mathrm{m}^{2}$ de área ütil. As seis parcelas que compõem 0 experimento possuem dimensão de 14 × 35 m e estão distribuidas em três para cada preparo do solo (convencional, subsola gem), conforme pode ser observado na Figura 1 .

\section{2 .2 . Solo}

O solo do local é classificado por RANZANI et alii (1966) como uma Terra Roxa Estruturada (Alfisol, de acordo com a 7ạ aproximação), série "Luiz de Queiroz". De acordo com a classificação americana (EUA, 1975), é um Paleudalf óxico. Este tipo de solo apresenta um pexfil homogêneo e muito profundo, com o lençol freático a vários metros abai xo de sua superficie. Segundo Moniz e Jackson, citados por LIBARDI (1984), estudando este mesmo solo sob o ponto de vis ta mineralógico, em local diferente, encontraram que o teor de óxido de ferro $\left(\mathrm{Fe}_{2} \mathrm{O}_{3}\right)$ é de 15,3\% no solo seco ao ar eque 
na argila livre de óxido de ferro existem $48 \%$ de caulinita, $10,7 \%$ de mica + vermiculita, 4,3\% de gibsita e 31,7\% de maté ria amorfo.

\subsubsection{Planta}

Para estudo neste trabalho, escolheu-se

um cultivar de milho (AGROCERES 401) que, além de ter bastante aceitação comercial na região, é um híbrido que se adapta às condições de semeadura tardia para a região centro-sul do país. Outro fator que influenciou na escolha de um híbrido é que estes apresentam alta capacidade de produção, superando amplanta qualquer outro cultivar disponível, principalmen te quando em semaduras tardias. O cultivar AGROCERES 401 aprssenta como principais caracteristicas: florescimento médio em 61 dias para o Brasil central, altura média de plantas $2,50 \mathrm{~m}$, altura média de insercão das espigas $1,50 \mathrm{~m}$, cor do sabugo branca, grão de cor alaranjada e tipo semi-duro 11/2 dente). E um híbrido indicado palra colheita mecanizada, pois é resistente ao tombamento. A papulação média de plantas recomendada por hectare é de 45000 plantas e o espaçamen to entre Iinhas de 0,90 a $1,00 \mathrm{~m}$.

\subsubsection{Clima}

O clima da região, segundo a classificação cli mática de Wilhelm Köeppen, que associa estudo da vegetação 
com valores numéricos de temperatura e precipitação das regiões, é tipo Cwa: sub-tropical úmido de inverno seco, com temperatura média do mês mais frio inferior a $18^{\circ} \mathrm{C}$ e a média do mês mais quente entre 22 e $24^{\circ} \mathrm{C}$. Dados meteorolóyicos co letados na estação meteorológica permanente instalada no local desde 1917, e pertencente ao Departamento de Físicae Meteorologia da ESALQ/USP, mostram que o total de chuvas do mês mais seco não ultrapassa, em média, $30 \mathrm{~mm}$, com um total anual oscilando entre 1200 e $1300 \mathrm{~mm}$ (1247 mm), e que a maior parte da precipitação ocorre durante o verão (de novembro a fevereiro), principalmente como chuvas de alta intensidade e curta duração. VILLA NOVA et alii (1973) também observaram outros parâmetros climáticos, como: a temperatura média anual do ar é de $20,8^{\circ} \mathrm{C}$, sendo que a minima ocorre em julho e a máxima em janeiro, na ordem de 10 e $30^{\circ} \mathrm{C}$, respectivamente. O periodo de brilho solar médio anual é de $6 \mathrm{~h} \cdot \mathrm{dia}^{-1}$, a umida de relativa média anual é $69 \%$ e a velocidade do vento média anual é $2,5 \mathrm{~m} \cdot \mathrm{s}^{-1}$.

\subsection{Instalação do experimento}

\subsubsection{Preparo do solo}

Utilizaram-se dois tipos de preparo do solo: convencional, fazendo-se uma aração e duas gradagens com gra- 
de pesada e grade leve; subsolagem a $50 \mathrm{~cm}$, seguida de uma gradagem pesada e uma gradagem leve. O subsolador era do ti po bico de pato com duas hastes distanciadas entre si de 35 cm, que foi passado uma vez no sentido do declive norte-sul e duas vezes no sentido leste-oeste do experimento. A gradạ gem pesada atingiu uma profundidade média de $30 \mathrm{~cm}$ em ambos os tratamentos, enquanto a gradagem leve serviu para um melhor destorroamento do solo. Antes da semeadura, passou-se uma enxada rotativa em toda a área experimental para uma meIhor uniformização dos primeiros 6 a $7 \mathrm{~cm}$ do solo.

\subsubsection{Semeadura e população de plantas}

A semeadura foi realizada no dia 7 de feverei ro de 1984, manualmente, em sulcos feitos com enxada, com aproximadamente $10 \mathrm{~cm}$ de profundidade. Foram semeadas 30 a mais de sementes como margem de seguxança, para se obter uma população proporcional a 50000 plantas/ha posteriormente à e mergência. Após realizada a semeadura, houve uma irrigação na ārea experimental, num período de 1 hora, para que fosse homogeneizada a umidade do solo. A emergência ocorreu no sex to dia após a semeadura e no décimo-quarto dia processou-se o desbaste, para uniformização do espaçamento entre plantas nas linhas. 
3.4. Práticas culturais

\subsubsection{Adubação}

A adubação constou da aplicação de quantidades de adubo proporcionais a: $60 \mathrm{Kg} / \mathrm{ha}$ de $\mathrm{P}_{2} \mathrm{O}_{5}$, na forma de superfosfato simples; $30 \mathrm{~kg} / \mathrm{ha}$ de $\mathrm{K}_{2} \mathrm{O}$, na forma de cloreto de potássio, e $30 \mathrm{~kg} / \mathrm{ha}$ de $\mathrm{N}$, na forma de uréia. Todos os cālculos foram realizados considerando a área, o espaçamento e o comprimento da linha de plantas na parcela.

O nitrogênio foi aplicado $1 / 3$ na semeadura (10 Kg/ha) e $2 / 3$ em cobertura $(20 \mathrm{~kg} / \mathrm{ha})$, aos 45 diaśs após a semeadura. Os adubos foram pesados separadamente, misturados e colocados em copos plásticos, em quantidades equivalen tes a uma linha, onde foram distribuídos e incorporados manualmente nos sulcos. Em cada linha dos dois preparos do so lo foram distribuidos 327, 420, $513 \mathrm{~g}$ de $\mathrm{P}_{2} \mathrm{O}_{5} ; 49,63$, $77 \mathrm{~g}$ de $\mathrm{K}_{2} \mathrm{O}$, e 43, 55, 68 de $\mathrm{N}$ para os espaçamentos entre-linhas de $0,70,0,90$ e $1,10 \mathrm{~m}$, respectivamente.

\subsubsection{Capinas, aplicações de defensivos e amontoa}

As capinas for am em nümero de duas, no 189 e 54 9 dia após a semeadura, para evitar a competição por ägua, luz e nutrientes, das invasoras com o milho. Antes da implantação do experimento, a área apresentou-se infestada de tiririca (Cyperus rotundus L.), sendo necessária a aplicação 
de Roundup (Glyphosate), na proporção de 3,0 litros/ha. No decorrer do trabalho, foram precisas aplicações de inseticida Folidol EM 50\% (Parathion methyl), devido à presença de vaquinhas (Diabrotica speciosa) e a lagarta do cartucho (Spodoptera frugiperda (J.E. Smith, 1797) (Lepidoptera, Noctuidae)), na proporção de $20 \mathrm{~cm}^{3} / 20$ litros de água. Estas aplí cações foram efetuadas no $169,209,239$ e 369 dia após a semeadura. A amontoa foi realizada no dia 19 de março, isto é, 41 dias após a semeadura, com a finalidade de juntar terra próxima às raizes adventicias das plantas.

\subsubsection{Irrigações}

O controle da irrigação foi realizado através das observações diárias de tensiômetros instalados à profundidade de $45 \mathrm{~cm}$ na área experimental, devido ser a profundi dade com maior concentração radicular no máximo desenvolvi mento da cultura. As parcelas experimentais foram irrigadas toda vez que a tensão da água nessa profundidade do solo atingia 0,08 Mpa. Foram instalados de um modo longitudinal à área experimental, três linhas de sete aspersores, totalizan do 21 aspersores, distribuidos conforme mostra a Figura 1. Ajustou-se a pressão desejada de água para os aspersores por meio de um registro instalado na saida da bomba, sendo os as persores de engate rápido, com válvula automática, colocados sobre tubos de elevação de PVC de 25,4 mm de diāmetro e altü ra de 2,00, a fim de que holvesse perfeita cobertura de irri 
TABELA 1 - Identificação dos estádios de desenvolvimento de $\underline{u}$ ma cultura de milho (Zea mays L.), segundo HANWAY (1963). Piracicaba, SP, 1984.

\begin{tabular}{|c|c|}
\hline $\begin{array}{l}\text { Estädios de } \\
\text { Desenvolvimento } \\
\text { da Cultura }\end{array}$ & $\begin{array}{c}\text { Caracteristicas Verificadas } \\
\text { na Cultura do Milho }\end{array}$ \\
\hline 0 & Emergência de plantas no solo. \\
\hline 0,5 & $\begin{array}{l}\text { Duas folhas completamente formadas, uma se } \\
\text { mana apös plantas emergirem. }\end{array}$ \\
\hline 1 & $\begin{array}{l}\text { Quatro folhas completamente formadas, duas } \\
\text { semanas após plantas emergirem. }\end{array}$ \\
\hline 1,5 & $\begin{array}{l}\text { Seis folhas completamente formadas, três } \\
\text { semanas após plantas emergirem. }\end{array}$ \\
\hline 2 & $\begin{array}{l}\text { Oito folhas completamente formadas, qua- } \\
\text { tro semanas após plantas emergirem. }\end{array}$ \\
\hline 2,5 & $\begin{array}{l}\text { Dez folhas completamente formadas, cinco } \\
\text { semanas após plantas emergirem. }\end{array}$ \\
\hline 3 & $\begin{array}{l}\text { Doze folhas completamente formadas, seis } \\
\text { semanas após plantas emergirem. }\end{array}$ \\
\hline 3,5 & $\begin{array}{l}\text { Quatorze folhas completamente formadas, se } \\
\text { te semanas após plantas emergirem. }\end{array}$ \\
\hline 4 & $\begin{array}{l}\text { Dezesseis folhas completamente formadas, } \\
\text { oito semanas após plantas emergirem. }\end{array}$ \\
\hline 5 & $\begin{array}{l}\text { Presença dos estigmas, pólen abrigado, } 66 \\
\text { dias após emergência, inicio do estádio re } \\
\text { produtivo. }\end{array}$ \\
\hline 6 & $\begin{array}{l}\text { Estágio final da formaçäo dos estigmas, } 12 \\
\text { dias após inicio do estádio reprodutivo. }\end{array}$ \\
\hline 7 & $\begin{array}{l}\text { Estágio de formação de grão; o grão apre- } \\
\text { senta aspecto pastoso, } 24 \text { dias após ini- } \\
\text { cio do estádio reprodutivo. }\end{array}$ \\
\hline 8 & $\begin{array}{l}\text { Começo do enchimento de grão propriamente } \\
\text { dito; um pequeno número de grãos apresen- } \\
\text { ta dentes, } 36 \text { dias após início do estádio } \\
\text { reprodutivo. }\end{array}$ \\
\hline 9 & $\begin{array}{l}\text { Todos os grãos completamente dentados, } 48 \\
\text { dias após inicio do estádio reprodutivo. }\end{array}$ \\
\hline 10 & $\begin{array}{l}\text { Maturação fisiologica, } 60 \text { dias após ini- } \\
\text { cio do estäai reprodutivo. }\end{array}$ \\
\hline
\end{tabular}


gação na ärea experimental, durante todo o ciclo da cultura.

\subsection{Determinações realizadas}

\subsubsection{Fenologia}

O acompanhamento diário do ciclo da cultura foi realizado através de observações fenolóticas, propostas por HANWAY (1963) (Tabela 1), que permitem a identificação dos estádios de desenvolvimento do milho durante o ciclo.

\subsubsection{Análise de raízes}

Para a determinação das massas de raizes secas, nas camadas do perfil do soloe, consequentemente, sua distribuição no volume de solo, foram abertas duas trincheiras com dois metros de profundidade nas parcelas correspondentes ao espaçamento de $0,90 \mathrm{~m}$. A coleta das amostras foi efetuada aos 71 dias após a semeadura, através de monólitos de solo com $0,20 \times 0,20 \times 0,20 \mathrm{~m}$, conforme pode ser verifica do na Figura 2, seguindo metodologia usada por Gorbing, cita do por BOHM (1979); o volume total de solo coletado foi de $1,01 \mathrm{~m}^{3}(1,12 \times 0,90 \times 1,00 \mathrm{~m}$, Figura 2$)$. Cada amostra cole tada foi colocada em saco plástico para posterior secagem ao ar, destorroamento e peneiramento. As raizes retidas na peneira $(2,0 \mathrm{~mm})$ foram coletadas por catação, lavadas, secadas em estufa com ventilação forçada, a $70^{\circ} \mathrm{C}$, e pesadas em balan ça analitica. 


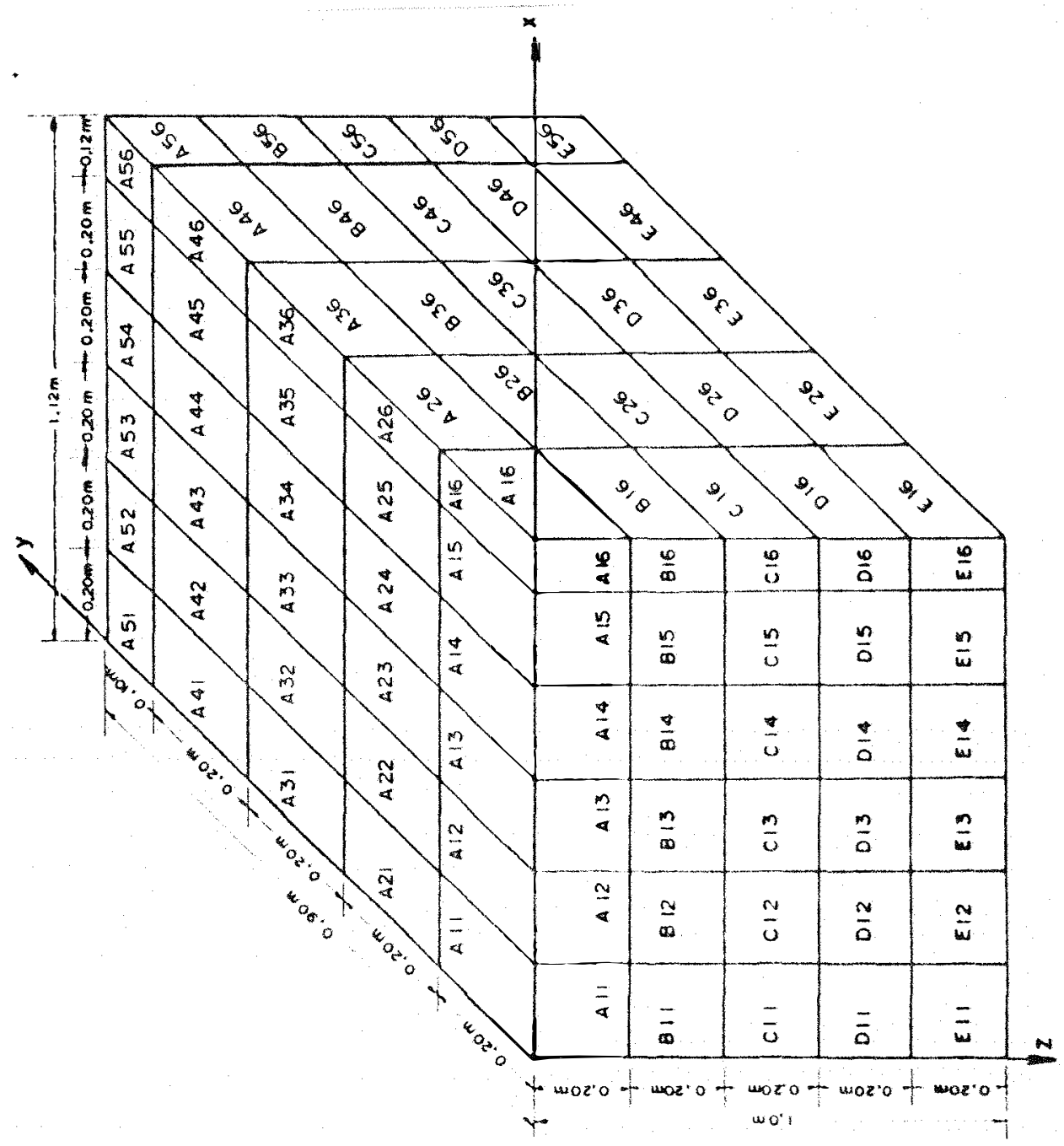

0

व

它.

$4=$

$+10$

4

0

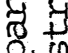

Q.

엉

(1)

क

Oू

告 8

응 융

合

过

䒕

है

당 영

요

号牙

$+\pi$

प्र

है है

O

T)

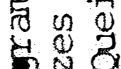

की

1
0
5
0
0
0 


\subsubsection{Radiação solar e precipitação}

A radiação solar global incidente foi obtida atravēs de dados registrados em piranômetro Eppley, instalado na cúpula do prédio do epartamento de física e Meteorolo gia da ESALQ/USP, distante $300 \mathrm{~m}$ do local do experimento. As caracteristicas deste instrumento são: Eppley Radiometer Modelo E-48A Serial 13740 - The Eppley Laboratory Inc. Para quantificação dos valores da radiação solar global incidente utilizou-se um integrador eletrônico de áreas da Lambda, Modelo LI 3000, pertencente ao Setor de Climatologia Agrícola do Departamento de Fitotecnia da Universidade Federal de San ta Maria (RS).

A precipitação ocorrida durante o ciclo da cul tura foi determinada com o auxilio de um pluviômetro do tipo "H.H.", instalado a $1,50 \mathrm{~m}$ da superficic do solo, no posto Agrometeorológico do Departamento de Eisica e Meteorologia da ESALQ/USP, distante $100 \mathrm{~m}$ do experimento.

\subsubsection{Caracteristicas morfológicas}

Durante todo o ciclo da cultura foi determina do o nümero de folhas por planta e altura de plantas, para cada tratamento, com três repetições. Estas observações foram realizadas em intervalos de dez dias, correspondendo a a mostragens de 4, 5 e 6 plantas, dos espaçamentos de 0,70, 0,90 e $1,10 \mathrm{~m}$, respectivamente. Também foi determinado o nú 
mero de espigas por planta, para os tratamentos estudados.

\subsubsection{Matēria seca}

As coletas de plantas para a determinação da matéria seca foram realizadas em intervalos constantes de dez dias, durante o ciclo da cultura. As plantas foram cortadas na linha e ao nível do solo, em número de 4, 5 e 6, para os espaçamentos de $0,70,0,90$ e $1,10 \mathrm{~m}$, respectivamente, nas duas condições de preparo do solo, com três repetições. A seguir, suas partes (folhas, colmos) foram separadas e levadas a uma estufa de ventilação forçada para secagem, a uma temperatura de $70^{\circ} \mathrm{C}$, onde permaneceram até atingirem peso constante. A partir do aparecimento dos pendões e espigas, estes foram incluídos no peso dos colmos. Os dados de cada uma das partes das plantas (folhas e colmo) e da planta toda foram submetidos à análise da variancia e também testada a re gressão que melhor se ajustava a eles.

\subsubsection{Area foliar}

No laboratório, efetuaram-se as medições do comprimento do limbo (C) e da maior largura (L) de cada foIha, de duas plantas, nas três repetições de cada tratamento. A área foliar (A) foi estimada através da expressão C X I X 0,75, proposta por MONTGOMERY (1911), e utilizada por inúmeros pesquisadores. O somatório das áreas foliares 
individuais das plantas permitiram a obtençäo da área foliar total de cada planta. As restantes 2,3 e 4 plantas dos res pectivos tratamentos e repetições, cuja massa do total de fo lhas secas por planta era conhecida, tiveram a estimativa de suas āreas foliares efetuadas a partir da relação entre a mé dia das massas de folhas secas e áreas foliares conhecidas.

\subsubsection{Produção por área}

Para determinar a produção, por área, de sabugos, de espigas sem palha e de grãos e tambëm do número médio de espigas por planta, foram coletadas amostras de plantas em cada subparcela, perfazendo um total de três repetições, para cada espaçamento no respectivo preparo do solo es tudado. A área total de amostragem para cada espaçamento foi de $10,5,13,5$ e $16,5 \mathrm{~m}^{2}$, correspondentes a cinco linhas de 1 metro linear.

\subsection{Tratamentos}

Neste experimento, foram utilizados seis tratamentos, a seguir relacionados: preparo do solo convencional com três espaçamentos entre-1inhas de 0,70,0,90 e 1,10 m, e preparo do solo subsolagem, com trés espaçamentos controlinhas de $0,70,0,90$ e 1,10 m, respectivamente. 


\subsubsection{Delineamento experimental}

O delineamento experimental usado foi o de blo cos casualizados, com parcelas subdivididas e três repetições. Cada bloco corresponde ao preparo do solo (convencional-subsolagem) e cada parcela corresponde aos espaçamentos entre-linhas de $0,70,0,90 \mathrm{e} I, 10 \mathrm{~m}$, respectivamente. As três subparcelas dos tratamentos apresentam 163,38 $\mathrm{m}^{2}$, correspondentes às repetições para as coletas das amostras de plantas.

\subsection{Obtenção de parâmetros fisiológicos}

A avaliação deste experimento foi realizada pela Análise Quantitativa de Crescimento, onde foram estudados os seguintes indices fisiológicos: Indice de Area Foliar (IAF), Produtividade Biológica (PB), Taxa de Crescimento da Cultura (TCC), Taxa de Crescimento Relativo (TCR), Taxa de Assimilação Líquida (TAL) e Razão de Ârea Foliar (RAF). As definições de tais indices a seguir, foram baseadas nas formulações preconizadas por diversos autores, citados por WATSON (1952). 


\subsubsection{Indice de Årea Foliar (IAF)}

E a área foliar total, considerando-se apenas uma página da folha, por unidade de área de terreno ( $\left.\mathrm{L}^{2} \cdot \mathrm{L}^{-2}\right)$.

\subsubsection{Produtividade Biolögica (PB)}

E a massa da matéria seca total da planta acu mulada por unidade de área de terreno $\left(M \cdot L^{-2}\right)$. No caso do presente experimento, foi feita uma análise de regressão entre a produtividade biológica com o tempo, ao longo do ciclo da cultura, tendo sido obtido para todos os tratamentos uma equação linear, isto é,

$$
P B=a+b t
$$

\subsubsection{Taxa de Crescimento da Cultura (TCC)}

Também conhecida como Taxa de Produção de Matéria seca Total, é a massa da matéria seca total acumulada por unidade de área de terreno e tempo $\left(M \cdot L^{-2} \cdot T^{-1}\right)$, istoé,

$$
\mathrm{TCC}=\frac{\mathrm{dPB}}{\mathrm{dt}}
$$

Nestas condições, tendo em vista a equação

(1), é claro que:

$$
\mathrm{TCC}=\mathrm{b}
$$


ou seja, a taxa de crescimento da cultura no presente estudo foi constante durante o ciclo e é igual ao coeficiente angular da curva $\mathrm{PB} \times \mathrm{t}$.

\subsubsection{Taxa de Crescimento Relativo}

Definida como sendo a taxa de crescimento da cultura (TCC) por unidade de massa de matéria seca da planta $\left(\mathrm{T}^{-1}\right)$, ou seja,

$$
T C R=\frac{1}{P B} \cdot \frac{d P B}{d t}
$$

Sendo $\mathrm{dPB} / \mathrm{dt}=\mathrm{TCC}=$ constante, $\overline{\mathrm{e}}$ evidente que no presente caso, a equação (4) se transforma em:

$$
T C R=\frac{T C C}{a+b t}
$$

\subsubsection{Taxa de Assimilação Líguida (TAL)}

Tambëm conhecida por alguns esquisadores como Taxa de Assimilação Aparente (TAA), é definida como sendo a taxa de crescimento da cultura (TCC) por unidade de área foliar $\left(\mathrm{M} \cdot \mathrm{L}^{-2} \cdot \mathrm{T}^{-1}\right)$, sto

$$
\text { TAL }=\frac{1}{A} \cdot \frac{d P B}{d t}
$$


onde A é a área foliar. A partir da análise de regressão de A $x t$, a equação obtida neste experimento foi da forma:

$$
A=a^{\prime}+b^{\prime} t+c^{\prime} t^{2}
$$

portanto, tendo em vista a definição (2) e as equaçōes (3) e (7), teremos que:

$$
\text { TAL }=\frac{b}{a^{\prime}+b^{\prime} t+c^{\prime} t^{2}}
$$

\subsubsection{Razão de Área Foliar (RAF)}

E o quociente entre a área foliar e a massa da matéria seca total da planta, ou entre o indice de área foliar e a produtividade biológica $\left(M^{-1} \cdot L^{2}\right)$, isto é:

$$
\mathrm{RAF}=\frac{\mathrm{A}}{\mathrm{Wt}}=\frac{\mathrm{IAF}}{\mathrm{PB}}
$$

onde wt é a massa da matéria seca total da planta. No caso dos resultados deste estudo, a relação entre o indice de área foliar (IAF) e o tempo ( $t$ ) após a emergência, foi quadrátí ca, do tipo:

$$
\operatorname{IAF}=a^{\prime \prime}+b^{n} t+c^{\prime \prime} t^{2}
$$


Portanto, substituindo (1) e (10) em (9), resulta:

$$
\operatorname{RAF}=\frac{a "+b " t+c " t^{2}}{a+b t}
$$

onde $a "$, b" e c" são iguais a a'/At; b'/At $e$ c'/At, respectivamente, sendo At a ärea do terreno $\left(L^{2}\right)$, considerada, no presente caso, para cada espaçamento; $a^{\prime}, b^{\prime}$ e c'os coe ficientes da equação (7) . 


\section{RESULTADOS}

\subsection{Condições meteorológicas.}

Os elementos meteorológicos usados neste trabalho foram a radiação solar e a precipitação pluviométrica, por serem os mais importantes para a cultura do milho. Os dados destes elementos, durante o ciclo da cultura, estão apresentados na Figura 3.

A radiação solar global apresenta valores oscilantes devido a flutuações ocasionadas pela nebulosidade. Os meses de fevereiro, março, abril e maio apresentam valores médios da radiação solar global de 679, 531, 417 e 375 cal. $\mathrm{cm}^{-2} \cdot \mathrm{dia}^{-1}$, respectivamente. A média de radiação para o ciclo da cultura foi de $422 \mathrm{cal} \cdot \mathrm{cm}^{-2} \cdot \mathrm{dia}^{-1}$. Cada ponto da radiação global da Figura 3 corresponde à média dos dez dias anteriores.

O total de precipitação pluviométrica durante 
RADIAC,ĀO SOLAR GLOBAL, em cal.cm-2. dio-1

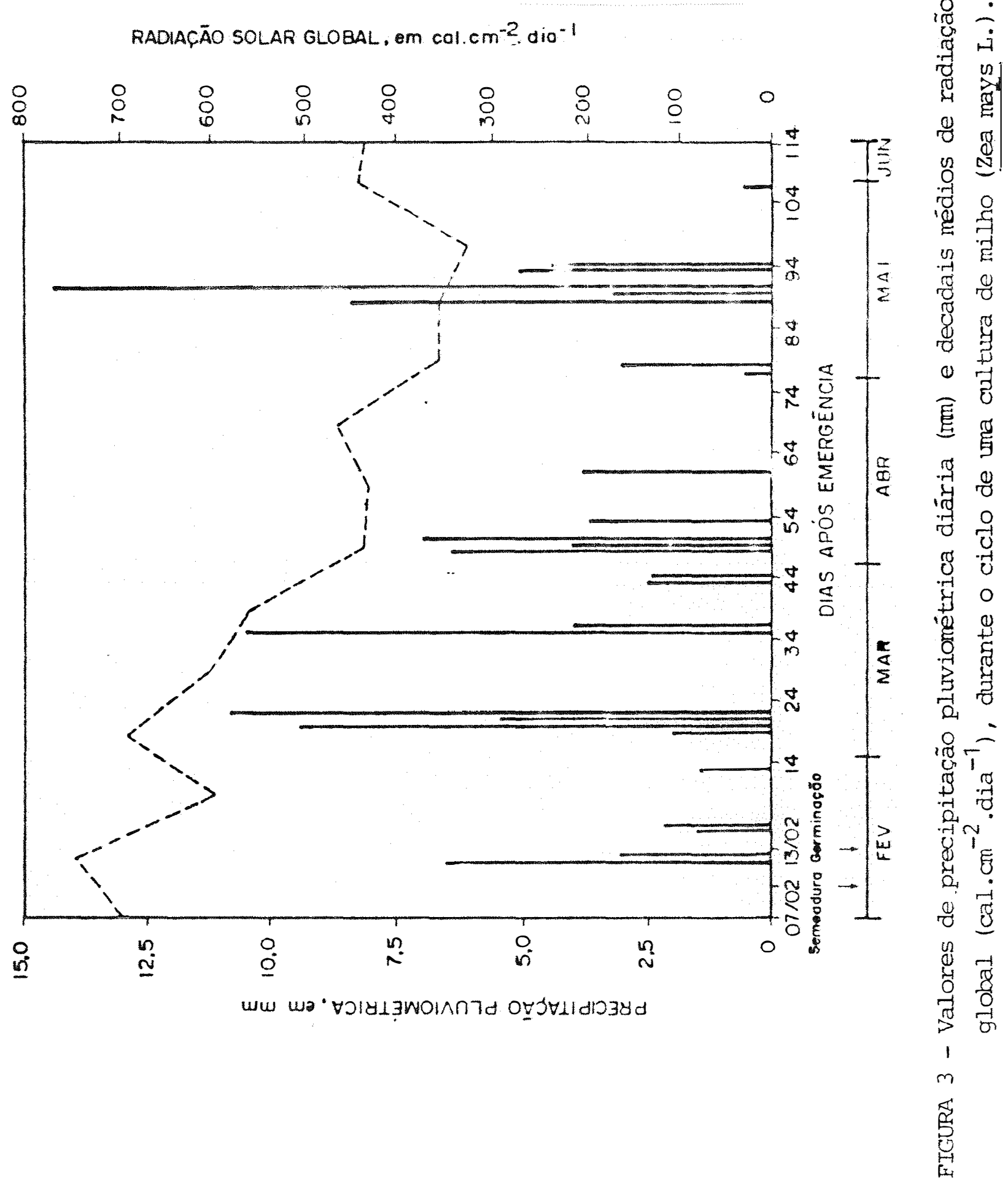

告 
o periodo experimental foi de 136,2 mm, valor inferior à média de precipitação deste local no período considerado. Os valores de precipitação registrados paraos meses de fevereiro, março, abril e maio foram de $18,7,46,625,0$ e 45,9, respectivamente. Foi realizado um grande número de irrigações, atravēs do sistema de irrigação por aspersão instalado na ärea experimental (ver Figural em "Material e Métodos").

\subsection{Caracteristicas morfolögicas}

\subsubsection{Altura das plantas}

Nas Tabelas 2 e 3 se observam as alturas máxi mas atingidas pelas plantas no preparo do solo convencional, que foram de $279,7,275,7$ e $278,5 \mathrm{~cm}$, aos 104 dias apōs emergência, para os espaçamentos de $0,70,0,90$ e $1,10 \mathrm{~m}$, res pectivamente. Para o preparo do solo com subsolagem, as mäximas alturas de plantas foram de 274,2 cm aos 114 dias, e 280,5 e 285,2 cm aos 104 dias após emergência, na ordem cres cente dos respectivos espaçamentos entre-linhas.

\subsubsection{Nümero de folhas}

O número médio de folhas por planta, em cada coleta, foi semelhante entre tratamentos e pode ser observado nas Tabelas 2 e 3 . Os valores mäximos para o preparo do solo 


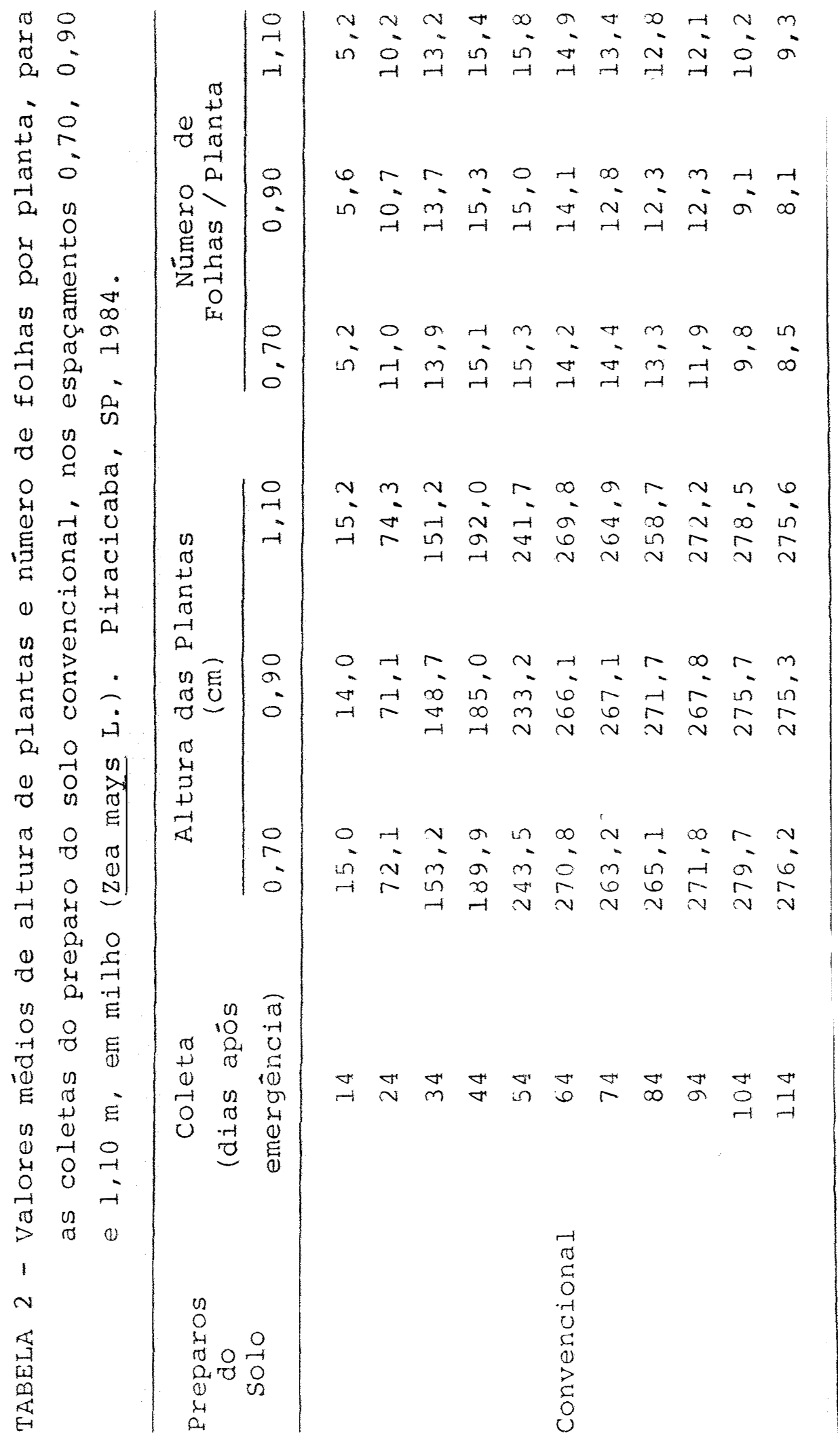




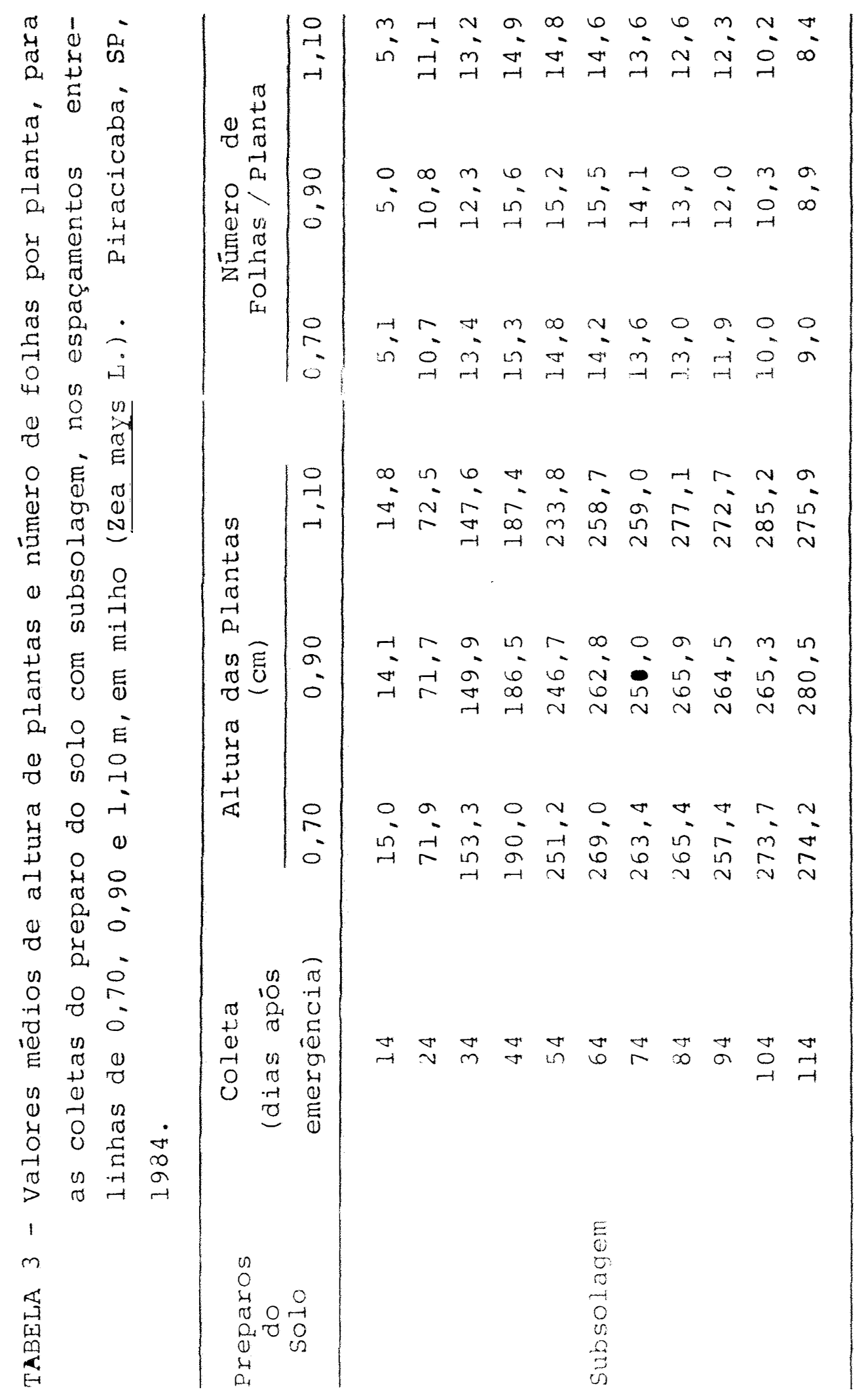


convencional (Tabela 2) foram de 15,3, 15,3 e 15,8 folhas por planta aos 54,44 e 54 dias após emergència, para os espaçamentos de 0,70, 0,90 e $1,10 \mathrm{~m}$, respectivamente. Para 0 preparo do solo com subsolagem (Tabela 3), foram de 15,3, 15,6 e 14,9, todos aos 44 dias após emergência, nos espaça mentos $0,70,0,90$ e $1,10 \mathrm{~m}$, correspondentes.

\subsubsection{Número de Espigas por planta}

No preparo do solo convencional, obtiveram-se valores de $1,87,1,92$ e 1,94, enquanto que para o preparo do solo com subsolagem, para os espaçamentos de 0,70, 0,90 e 1,10 m, respectivamente, 1,87, 1,95 e 1,98. Estes valores são dados médios de três repetições e estão contidos na Tabela 4 .

\subsubsection{Fenologia}

O acompanhamento fenológico do experimento, apresentado na Tabela 5, mostra que não houve diferenças entre os periodos de cada estädio de crescimento, nos tratamen tos estudados. A duração do ciclo do cultivar AGROCERES 401 utilizado neste trabalho foi de 118 dias, compreendido da emergência à maturação fisiológica. 


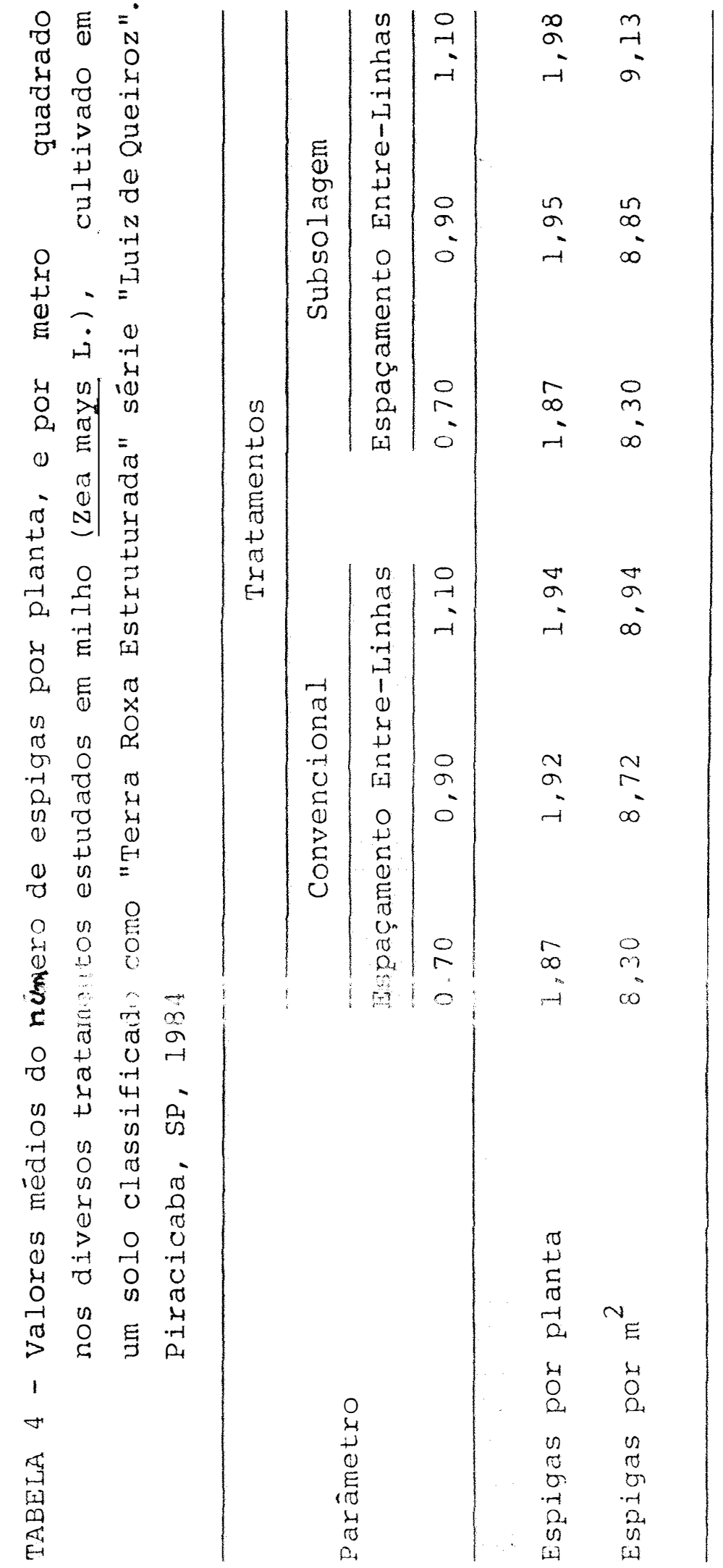




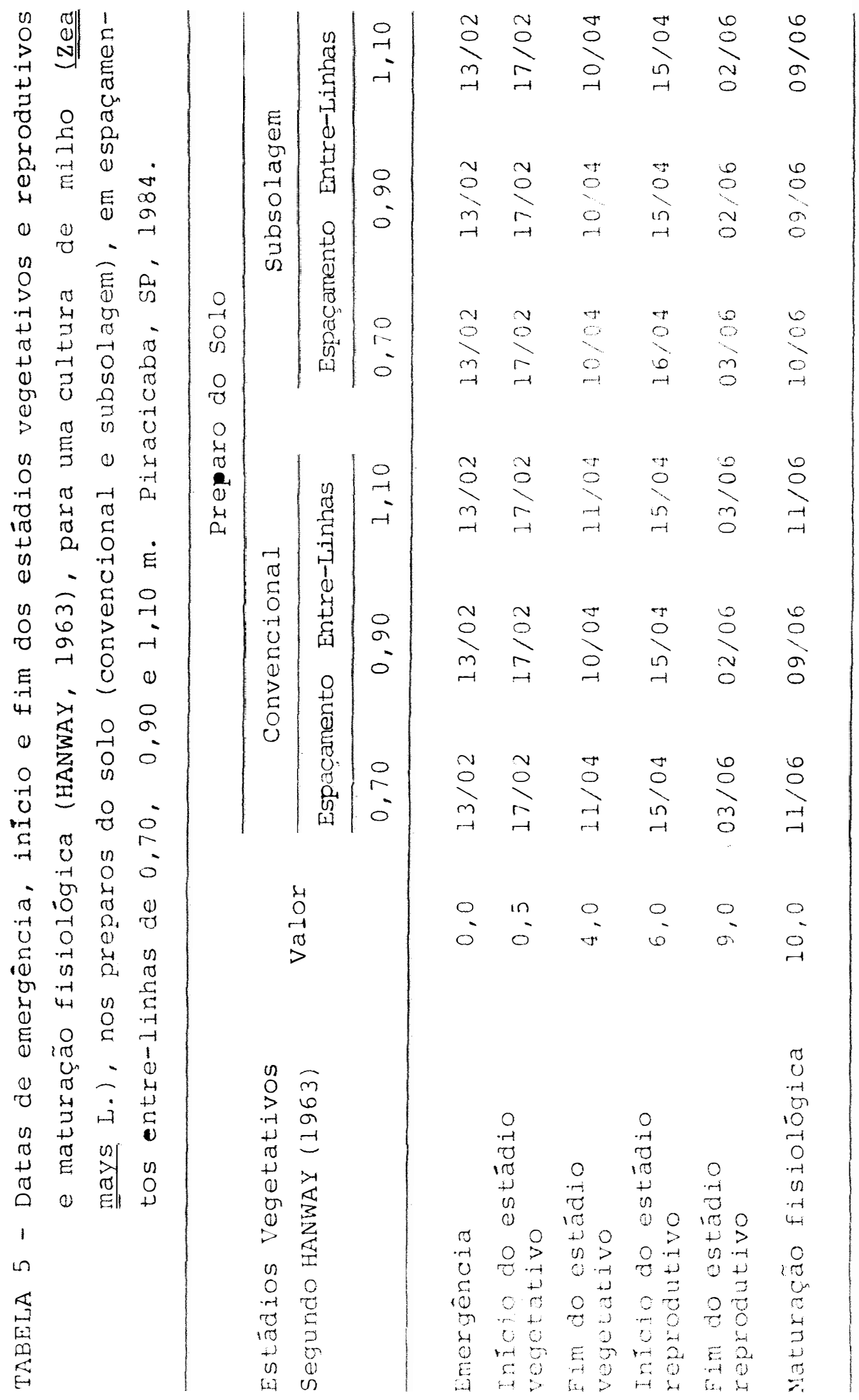




\subsection{Distribuição de raízes}

A massa total de raízes secas, coletadas dos monólitos de solo, nos dois sistemas de preparo do solo, foi de $1124,3 \mathrm{~g}$, sendo que 618,1 g corresponderam ao preparo do solo convencional e $506,2 \mathrm{~g}$ ao preparo do solo com subsolagem, conforme pode ser visto na Tabela 6 . Para o preparo de solo convencional, a camada de $20-40 \mathrm{~cm}$ foi a que contribuiu com a maior massa de raizes $(273,21 \mathrm{~g})$, correspondendo a 44,20\% do total no perfil. Para o preparo do solo com subso lagem, a maior contribuição foi da camada 40-60 cm $(339,64 \mathrm{~g})$, com $67,10 \%$ do total existente no perfil.

\subsection{Matëria Seca}

Os dados referentes à massa de matéria seca dos colmos, folhas e totais, ao longo do tempo, dos dois sis temas de preparo do solo e três espaçamentos entre-linhas, es tão apresentados has Tabelas 7 e 8 . As equações de regressão que melhor se ajustaram aos parâmetros e os respectivos coeficientes de determinação podem ser vistos nas Tabelas 9, 10 e 11 .

4.4.1. Matéria seca dos colmos

As curvas ajustadas de Wc para os tratamentos 


\begin{tabular}{|c|c|c|c|c|c|c|c|c|c|c|c|c|c|}
\hline 0 & 1 & ه & n & & & & & & & & & & \\
\hline$\nabla$ & r- & Q & E & & & 00 & & & & & & & \\
\hline ס & క & $\stackrel{\sigma}{E}$ & $\stackrel{.}{.-1}$ & • & & $\backsim \&$ & & $\stackrel{n}{n}$ & Ð & $\stackrel{\omega}{\sigma}$ & $\tilde{O}$ & $N$ & \\
\hline ס & 岀 & $\stackrel{0}{+}$ & $\overrightarrow{1}$ & $\infty$ & $E$ & rot & $\infty$ & $\dot{m}$ & à & $\infty$ & i & 6 & \\
\hline .7 & 4 & in & 0 & $\sigma$ & $\stackrel{0}{0}$ & $\ln _{0}$ & & & $m$ & $\varpi$ & -1 & 0 & \\
\hline : & $\Omega_{4}$ & n & $\begin{array}{l}4 \\
+3\end{array}$ & $\uparrow$ & $\pi$ & $\pi 0$ & & & & & & in & \\
\hline 3 & () & 0 & E & i & $\overrightarrow{0}$ & 20 & & & & & & & \\
\hline 욜 & $\underset{-1}{0}$ & $\stackrel{-1}{-1}$ & & $\omega$ & $\stackrel{\Omega}{\Omega}$ & & & & & & & & \\
\hline a. & 0 & $\pi$ & O & $\therefore$ & in & a d 0 & $\circ$ & 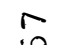 & 0 & $r$ & 6 & & 0 \\
\hline$\sigma$ & & n & ¿ & O & & $i_{i-1}$ & - & 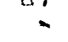 & - & - & ? & & - \\
\hline 10 & O & G & $\stackrel{Q}{\xi}$ & 0 & & $\begin{array}{ll}010 & 0 \\
& 0.4\end{array}$ & 饥 & $\overrightarrow{-1}$ & 6 & $a$ & $m$ & & aे \\
\hline$r$ & $\pi$ & - & 8 & - & & & & & & & & & -1 \\
\hline & ర్ & $\begin{array}{l}0 \\
0 \\
0\end{array}$ & $\begin{array}{l}0 \\
\Omega\end{array}$ & $\sigma$ & & & & & & & & & \\
\hline $\begin{array}{l}\text {-1 } \\
\text { on }\end{array}$ & हี & $\mathrm{N}$ & 0 & -r-1 & & 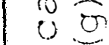 & & & & & & & \\
\hline 0 & & 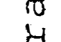 & 0 & & 7 & (1) & $\vec{m}$ & $\vec{v}$ & $\stackrel{\infty}{-1}$ & 0 & $\ddot{0}$ & -1 & \\
\hline 0 & 4 & 0 & E & 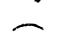 & 0 & $\theta N$ & - & $\therefore$ & ì & $\dot{m}$ & $\dot{m}$ & $\dot{m}$ & \\
\hline & بـ & ro & - & $\dot{i}$ & $\rightarrow-1$ & on & $\stackrel{O}{\sim}$ & m & ก & 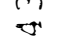 & $n-1$ & $w_{-1}$ & \\
\hline 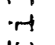 & - & $\pi$ & $\hat{\Xi}$ & 10 & $\Xi$ & 00 & & $\sim$ & $N$ & & & 10 & \\
\hline$\stackrel{4}{4}$ & 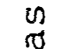 & $N$ & 0 & $>$ & $\stackrel{0}{>}$ & $\sum \pi$ & & & & & & & \\
\hline $\begin{array}{l}\mathcal{Q} \\
\Omega\end{array}$ & $\begin{array}{l}U \\
0\end{array}$ & $\pi$ & $\pi_{-1}^{\pi}$ & 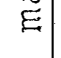 & $\stackrel{c}{0}$ & (n) & & & & & & & \\
\hline O & $\Omega$ & $\vec{n}$ & $\begin{array}{l}0 \\
\text { in }\end{array}$ & $\begin{array}{l}\pi \\
0\end{array}$ & 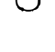 & $\stackrel{O}{O}$ & $\pi$ & $\stackrel{o}{\sim}$ & $m$ & 8 & $\stackrel{m}{\sim}$ & & 0 \\
\hline द & n & r-1 & 윽 & 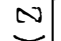 & & ${ }^{r-1}$ & $=$ & $\therefore$ & - & $\therefore$ & - & & j \\
\hline n & $\mathrm{N}$ & & $\overrightarrow{0}$ & 1 & & 保 & & $\exists$ & $\sigma$ & $\pi$ & $v$ & & - \\
\hline$\underset{N}{N}$ & $\pi$ & $\frac{5}{6}$ & 0 & ב & & & & & & & & & $\neg$ \\
\hline $\begin{array}{r}\text { rnd } \\
\text { ro }\end{array}$ & 4 & بn & -1 & .r- & & & & & & & & & \\
\hline 0 & व & 4 & $\tilde{E}$ & $E$ & 0 & 0 & & & & & & & \\
\hline 0 & $=$ & ه & . & ס & 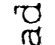 & ס & O & ? & 0 & ? & 0 & & \\
\hline & ח2 & $\Xi$ & U. & $\pi$ & 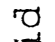 & .7 & 0 & 0 & 0 & ○ & 0 & & \\
\hline & E & 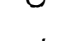 & (1) & 3 & ד & $4-1$ & & & & & $\rightarrow$ & & \\
\hline & $\frac{\pi}{4}$ &.-1 & c & $\stackrel{+}{+}$ & $\stackrel{G}{g}$ & 0 & 1 & 1 & 1 & 1 & 1 & & \\
\hline 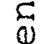 & or & 4 & 0 & 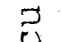 & 4 & Dr & 0 & -1 & -1 & -1 & -1 & & \\
\hline U & $\underset{0}{E}$ & a & $\sim$ & $\sigma$ & 4 & ¿ & 0 & o & 0 & 0 & 응 & & \\
\hline 0 & $=$ & 0 & -1 & ro & & & & & & & & & \\
\hline 0 & 0 & 8 & $\begin{array}{l}0 \\
n\end{array}$ & $\begin{array}{l}y \\
\pi\end{array}$ & & & & & & & & & \\
\hline 100 & $\begin{array}{l}02 \\
0\end{array}$ & 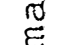 & 0 & $\Omega$ & & & & & & & & & $\stackrel{0}{0} \underset{N}{0}$ \\
\hline$\sqrt[3]{3}$ & $\Xi$ & .7 & & $\xi$ & & & & & & & & $\pi$ & $\pi$ \\
\hline$\frac{2}{r-1}$ & $\dot{E}$ & $\stackrel{100}{\sharp}$ & & ㅇ. & & & & & & & & $\pi^{0}$ & $\underset{. \sim}{E} \widetilde{A}$ \\
\hline 4 & 0 & $-r$ & $\pi$ & $\therefore$ & & & & & & & & n & $x 0$ \\
\hline in & 0 & ర్ & 0 & & -1 & & & & & & & 00 & $\sum \pi$ \\
\hline$\stackrel{4}{0}$ & $\begin{array}{c}0 \\
0 \\
0\end{array}$ & 8 & & 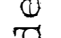 & 0 & 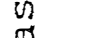 & & & & & & $+\pi$ & \\
\hline & & & & & (0) & 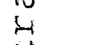 & & & & & & $E \rightarrow 0$ & Oir \\
\hline 1 & & & & & O & in & & & & & & 00 & $\pi$ \\
\hline 6 & & & & & & 0 & & & & & & 0 & $-7 \mathrm{~N}$ \\
\hline 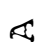 & & & & & $\begin{array}{l}0 \\
0 \\
0\end{array}$ & $\overline{\mathrm{C}} \underset{r+\mathrm{N}}{\mathrm{N}}$ & $\varangle$ & $\infty$ & $U$ & a & 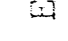 & $\stackrel{0}{\infty} n$ & ב. \\
\hline 足 & & & & & 0 & $\pi$ & & & & & & 0 & $\begin{array}{l}3 \\
4-1\end{array}$ \\
\hline$\kappa$ & & & & & $E$ & & & & & & & in $r+1$ & 0 in $E$ \\
\hline & & & & & 0 & $\Omega$ & & & & & & $\alpha_{1} a_{1}$ & $5 \%$ \\
\hline
\end{tabular}




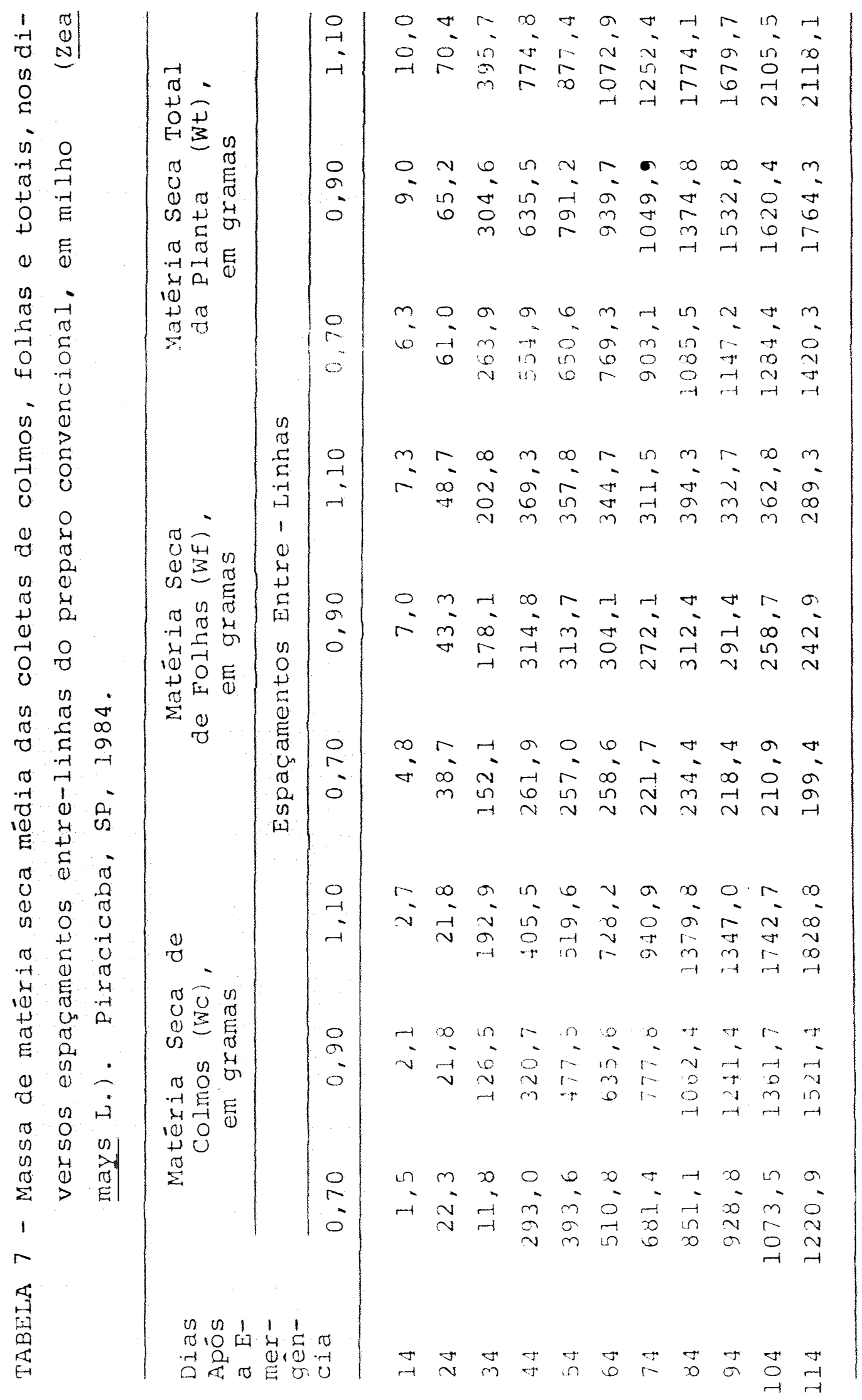




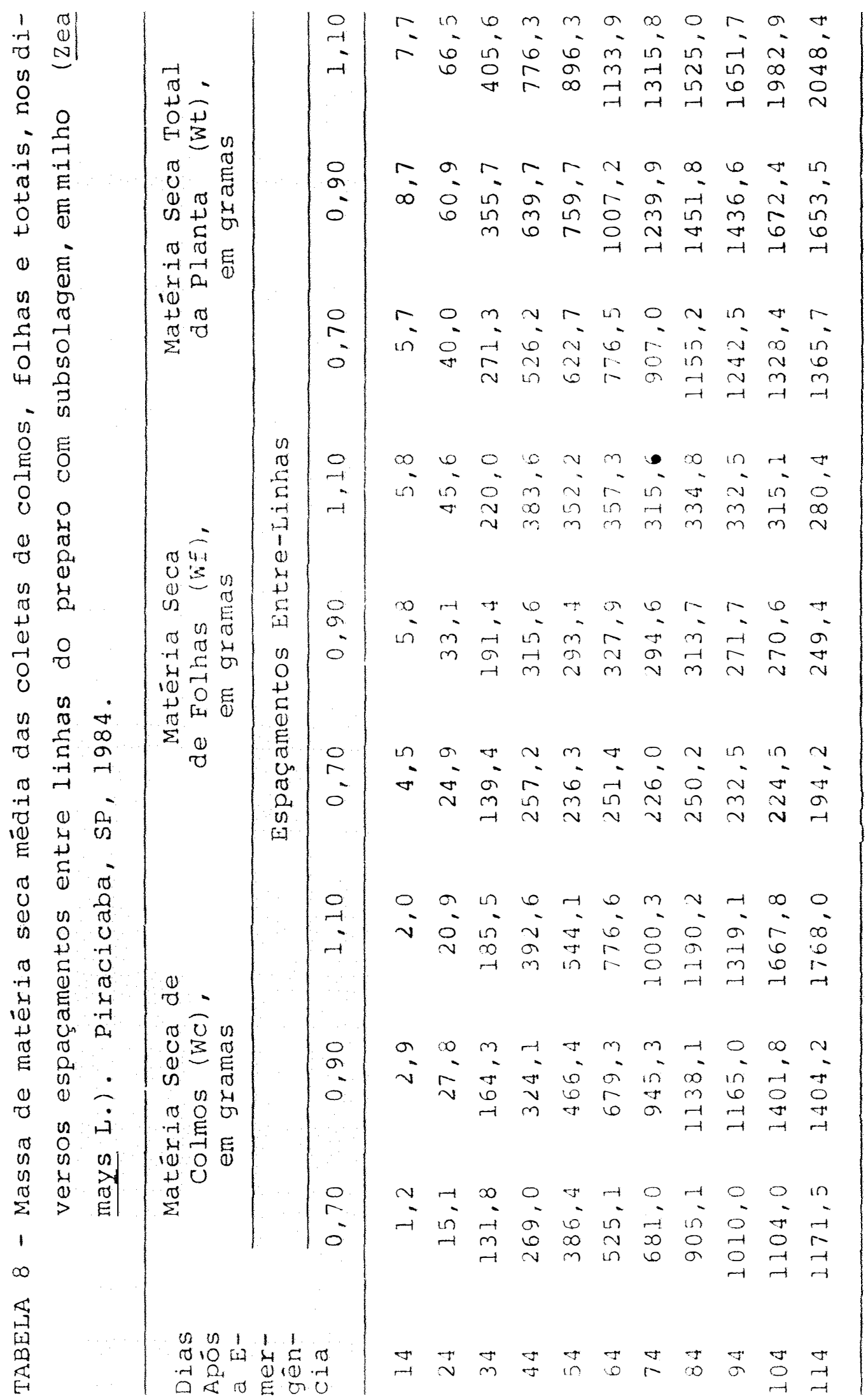




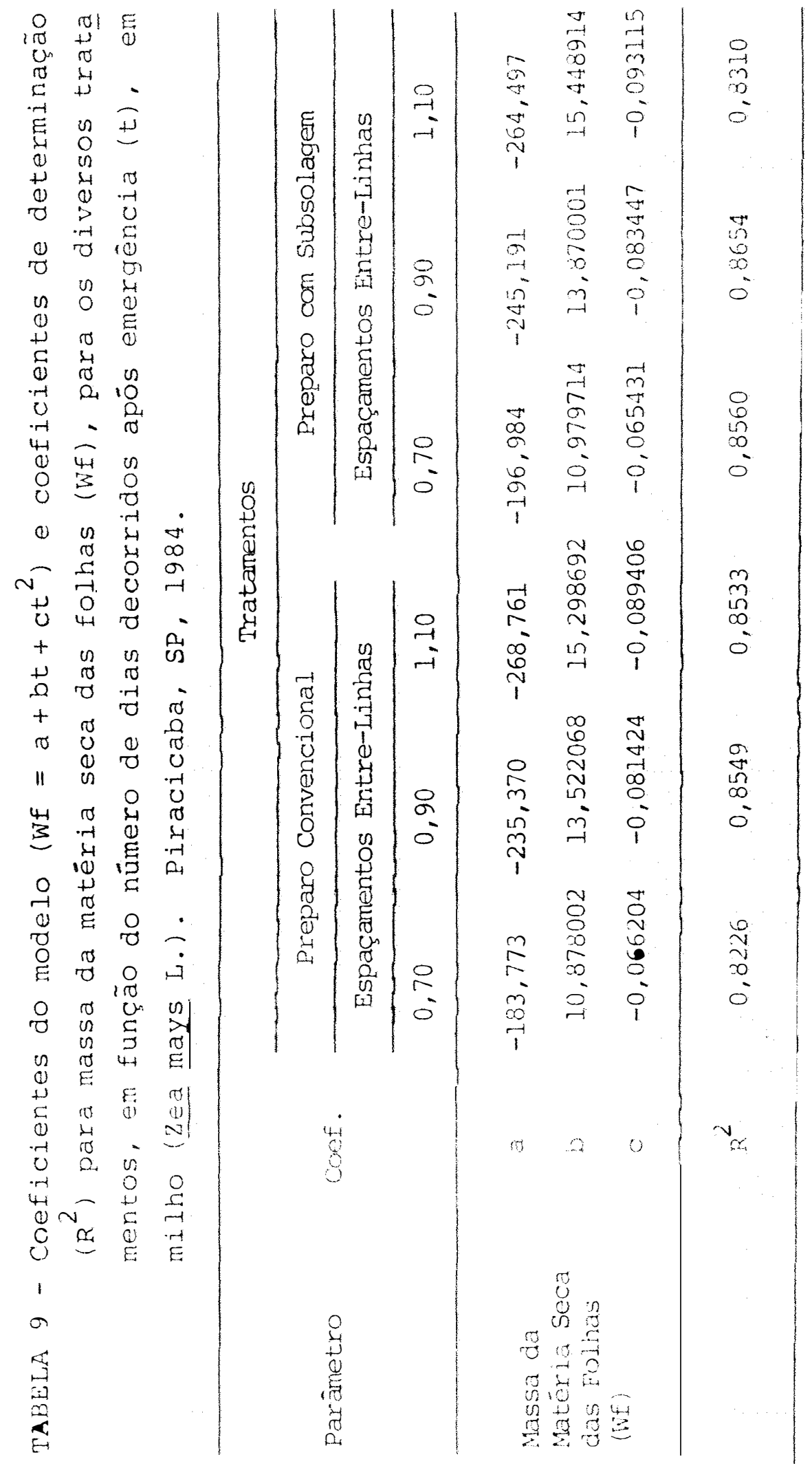




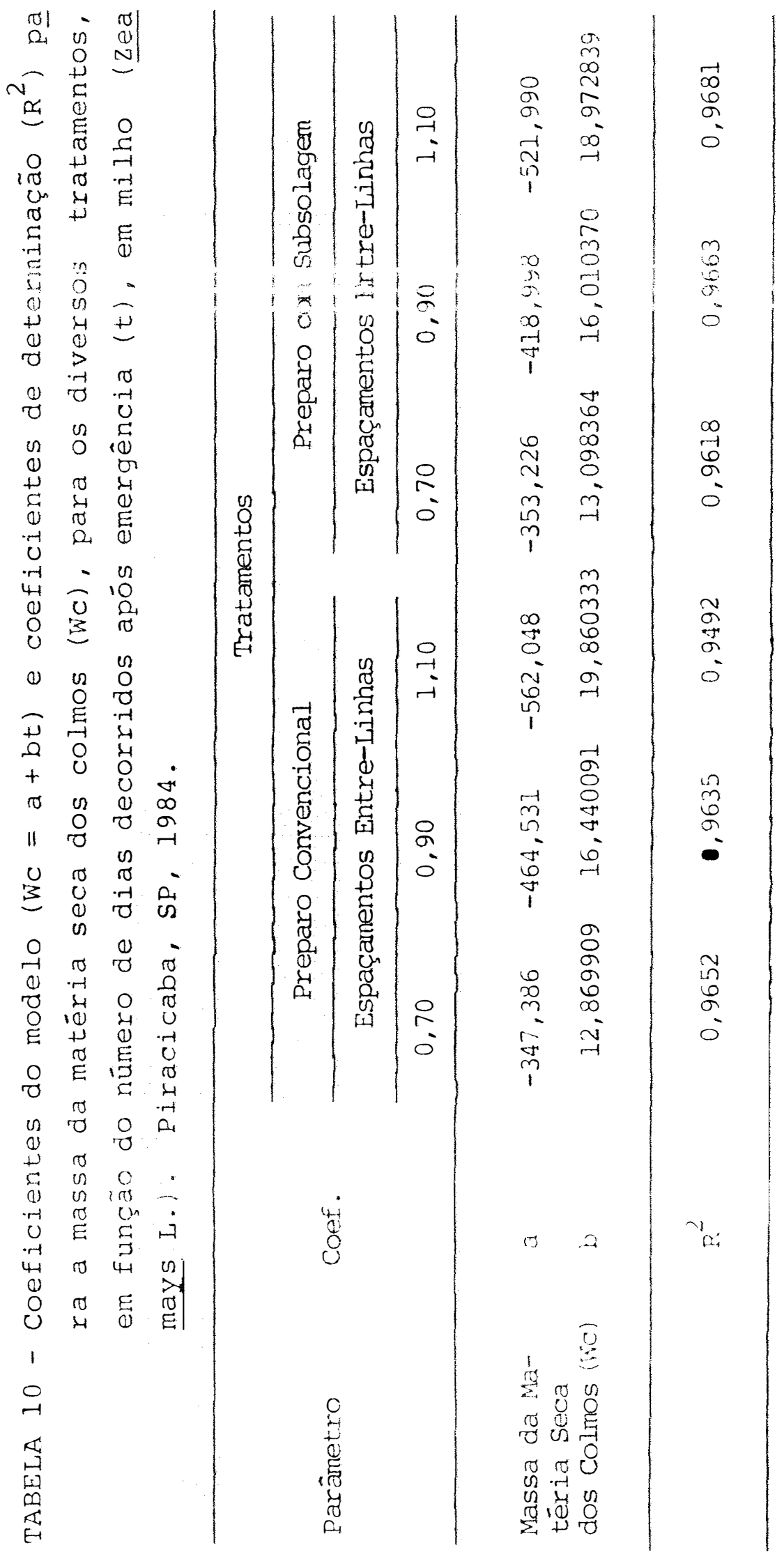




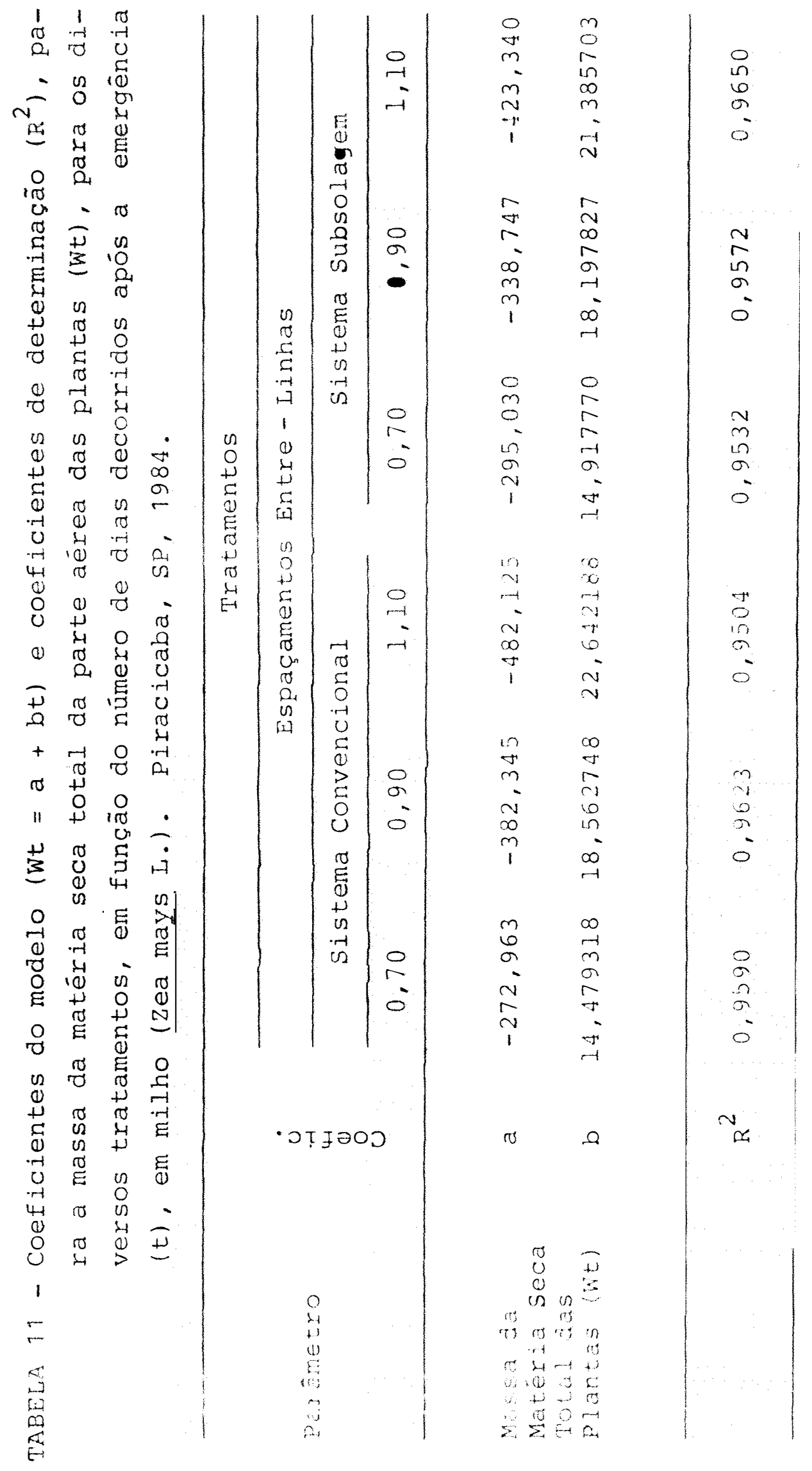


convencional e com subsolagem estão representadas nas Figuras 4 e 5, respectivamente para os três espaçamentos estudados. Nas Tabelas 7 e 8 estão as médias de Wc calculadas para cada época de coleta. O valor máximo, em gramas, alcança dos no preparo do solo convencional a nos esparamentos entre linhas de $0,70,0,90 \in 1,10 \mathrm{~m}$, foram de: 1220,9, 1521,4e $1828,8 \mathrm{~g}$, respectivamente. No preparo do solo subsolagem com os mesmos espaçamentos entre-linhas, foram atingidos valores mäximos de 1171,5, 1404,2 e 1768,0 g.

\subsubsection{Matéria seca das folhas}

As curvas ajustadas de wf para os três espaça mentos estão representadas nas Figuras 6, 708 , para os dois tipos de preparo do solo estudados. Os valores máximos, em gramas, alcançados no preparo do solo convencional, nos espa çamentos entre-linhas de $0,70,0,90 \mathrm{e} 1,10 \mathrm{~m}$, foram de: aos 64 dias, 258,6; aos 44 dias, 314,8 e aos 44 dias, 369,3, respectivamente. No preparo do solo com subsolagem, para os mesmos espaçamentos, foram atingidos valores máximos de 257,2 aos 44 dias, 327,9 aos 64 dias e $383,6 \mathrm{~g}$ aos 44 dias após a emergência. Os valores médios de wf calculados para cada época de coleta estão apresentados nas Tabelas 7 e 8 . 


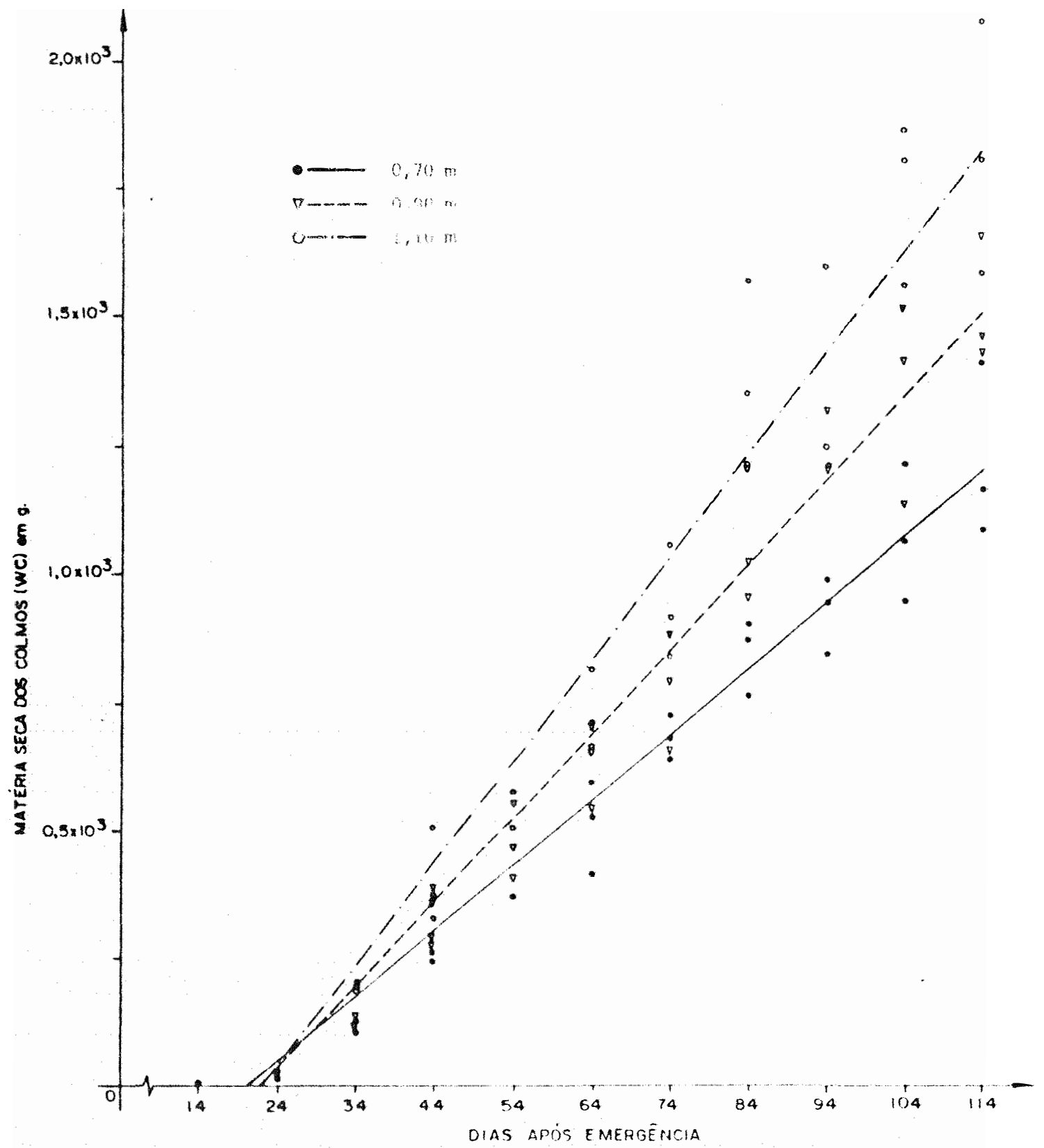

FIGURA 4 - Massa média de matéria seca dos colmos (Wc) em gramas, para o tratamento convencional, nos diversos espaçamentos, em uma cultura de milho (Zea mays L.), durante o ciclo em dias após emergência $(t)$. 


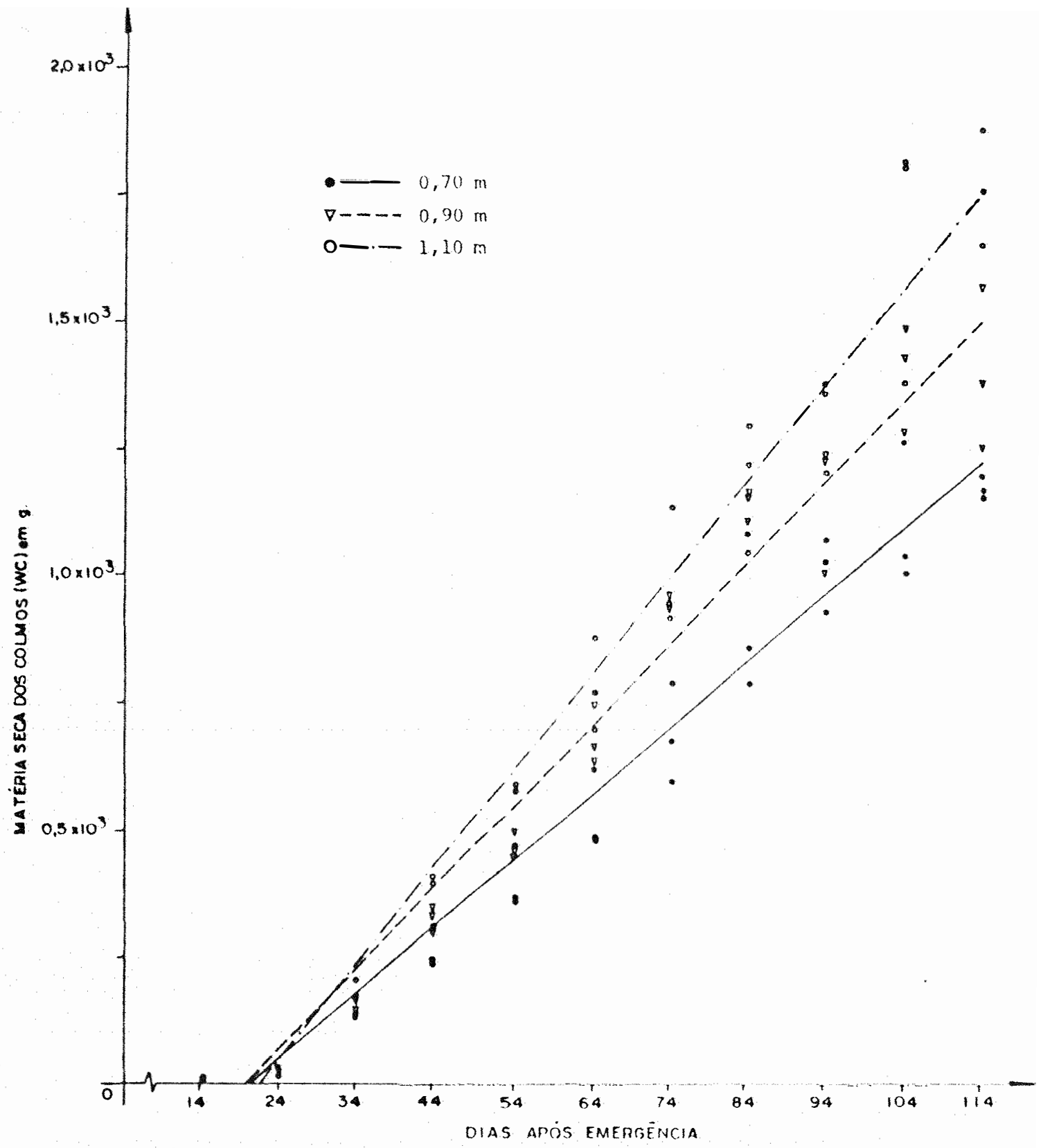

FIGURA 5 - Massa média de matéria seca dos colmos (Wc) em gramas, para o tratamento com subsolagem, nos diversos espaçamentos, em uma cultura de milho (Zea mays $L_{.}$), durante o ciclo em dias após emergência $(t)$. 


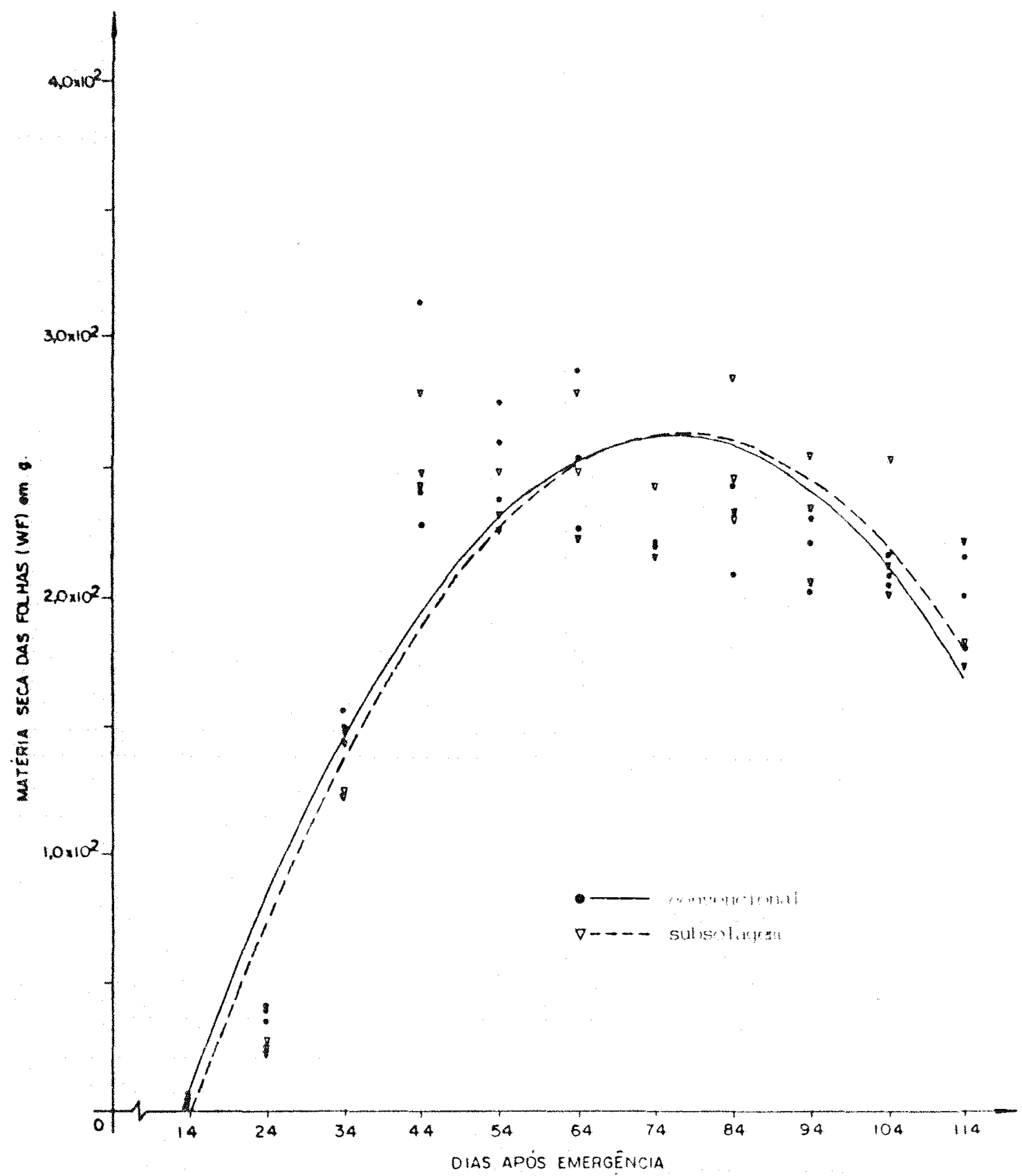

FIGURA 6 - Massa média de matéria seca das folhas (Wf) em gramas, para os dois sistemas de preparo do solo, no espaçamento entre-linhas, de $0,70 \mathrm{~m}$, en una cultura de milho (Zea mays L.), durante o ciclo em dias após a omoróncia $(t)$. 


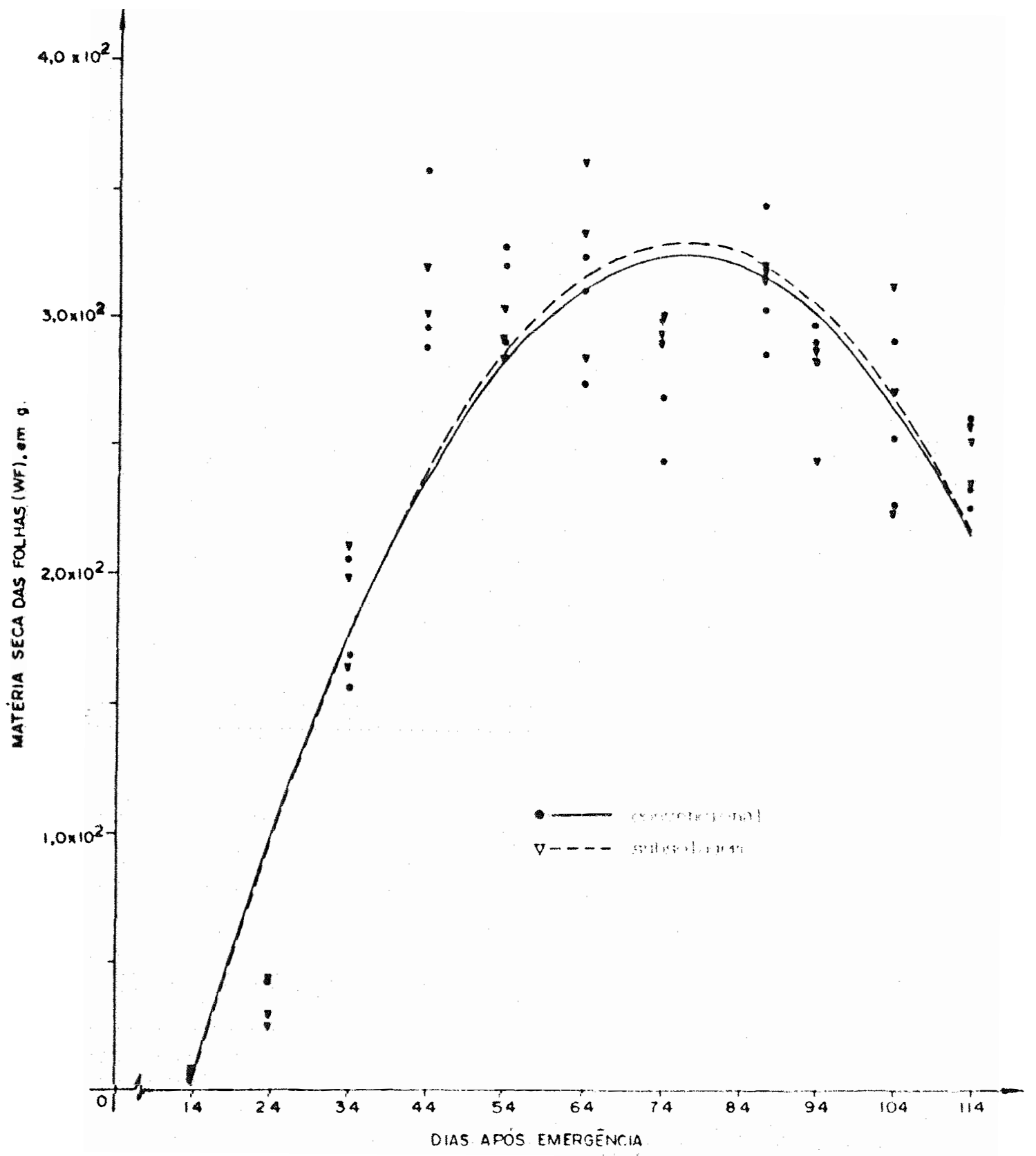

FIGURA 7 - Massa média de metéria seca das folhas (Wf) em gramas, para os dois sistemas de preparo do solo, no espaçamento entre-linhas de $0,90 \mathrm{~m}$, en uma cultura de milho (Zea mays L.), du rante o ciclo em dias após a emergência. 


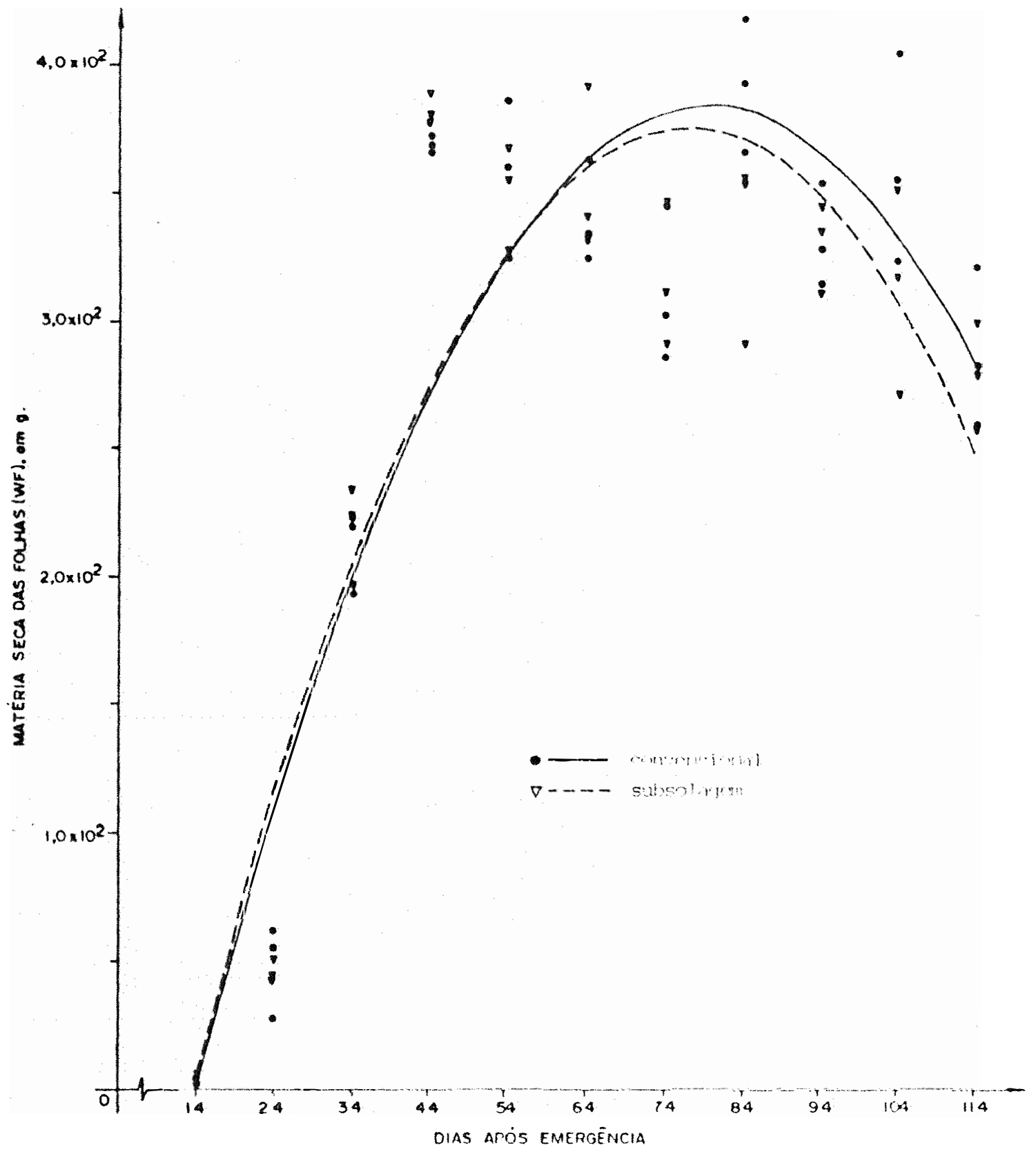

FIGURA 8 - Massa média de matéria seca das folhas (Wf) em gramas, para os dois sistemas de preparo do solo, no espaçamento entre-li nhas de $1,10 \mathrm{~m}$, em uma cultura de milho (Zea mays L.), durañ te o ciclo em dias após a emergência $(t)$. 


\subsubsection{Matéria seca total}

As curvas ajustadas de wt estão representadas nas Figuras 9 e 10.

Os valores máximos na área com preparo de solo convencional, nos três espaçamentos $0,70,0,90$ e. $1,10 \mathrm{~m}$ foram 1420,3, 1764,3 e 2118,1 g, respectivamente, e no pre paro com subsolagem: $1365,7,1672,4$ e 2048,4 g. Os valores médios para cada coleta, durante o ciclo da cultura, estão a presentados nas Tabelas 7 e 8 .

\subsection{Parâmetros fisiolōgicos}

\subsubsection{Indice de ärea foliar}

Os indices de ärea foliar (IAF) por coleta nos tratamentos estudados, são apresentados na Tabela 12 . As Pi guras 11 e 12 mostram as curvas ajustadas do IAF ao longo do ciclo da cultura, para os tratamontos convoncional e com sub solagem, respectivamente. De um modo geral, para o preparo do solo convencional, o valor mäximo de IAF foi atingido aos 64 dias após emerqência, enquanto que para o preparo do solo com subsolagem, aos 74 dias após emergência. Os valores mäximos de IAF por espaçamento foram de 3,54, 3,26 e 3,43 para o preparo do solo convencional, e 3,33, 3,52 e 3,26 para o preparo do solo com subsolagem, nos respectivos espaçamen- 


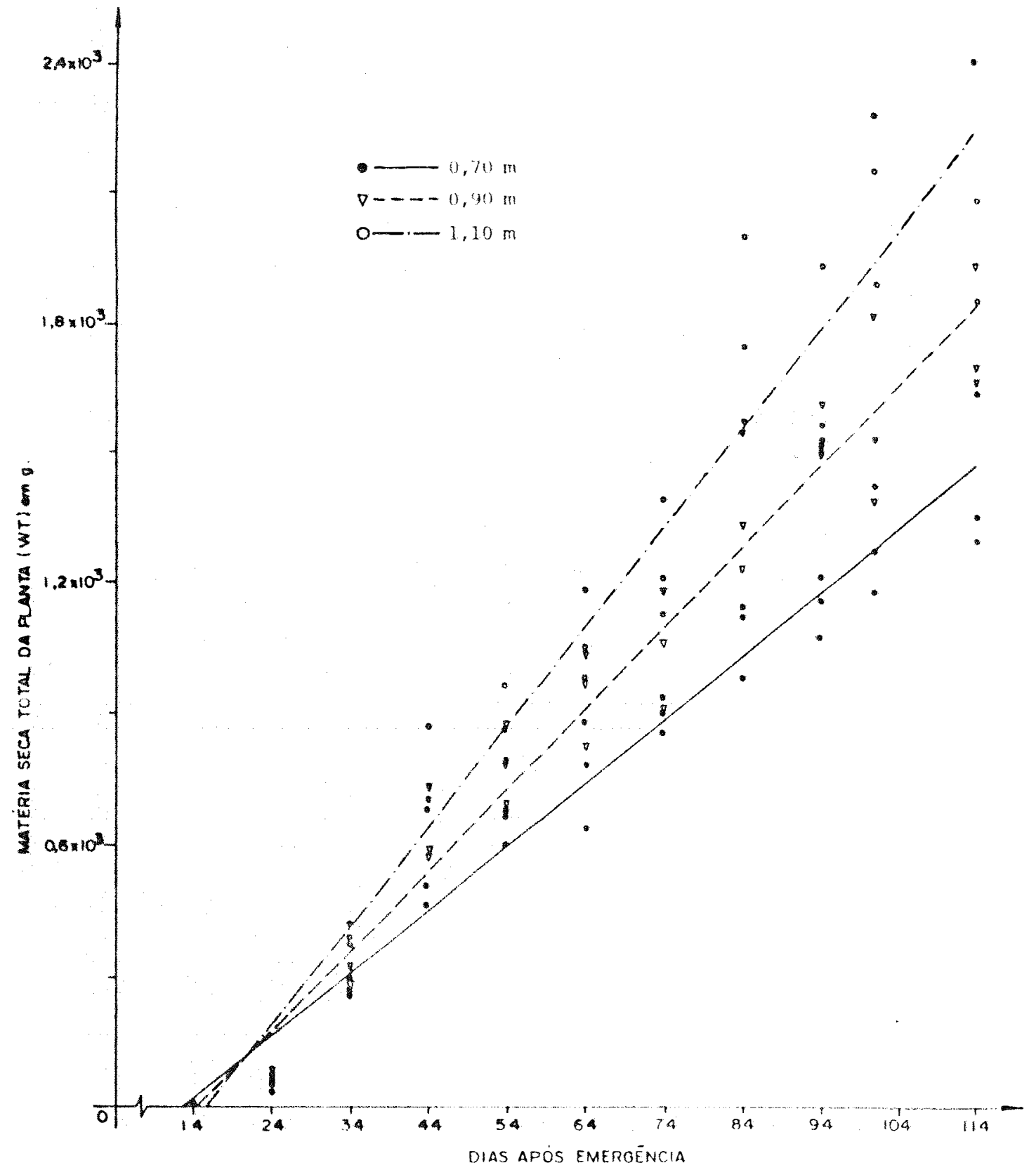

FIGURA 9 - Massa média de matéria seca total das plantas (Wt) em gramas, para o tratamento convencional, nos diversos espaçamentos, em una cultura de milho (Zea mays L.), durante o ciclo en dias apōs a emergência (t). 


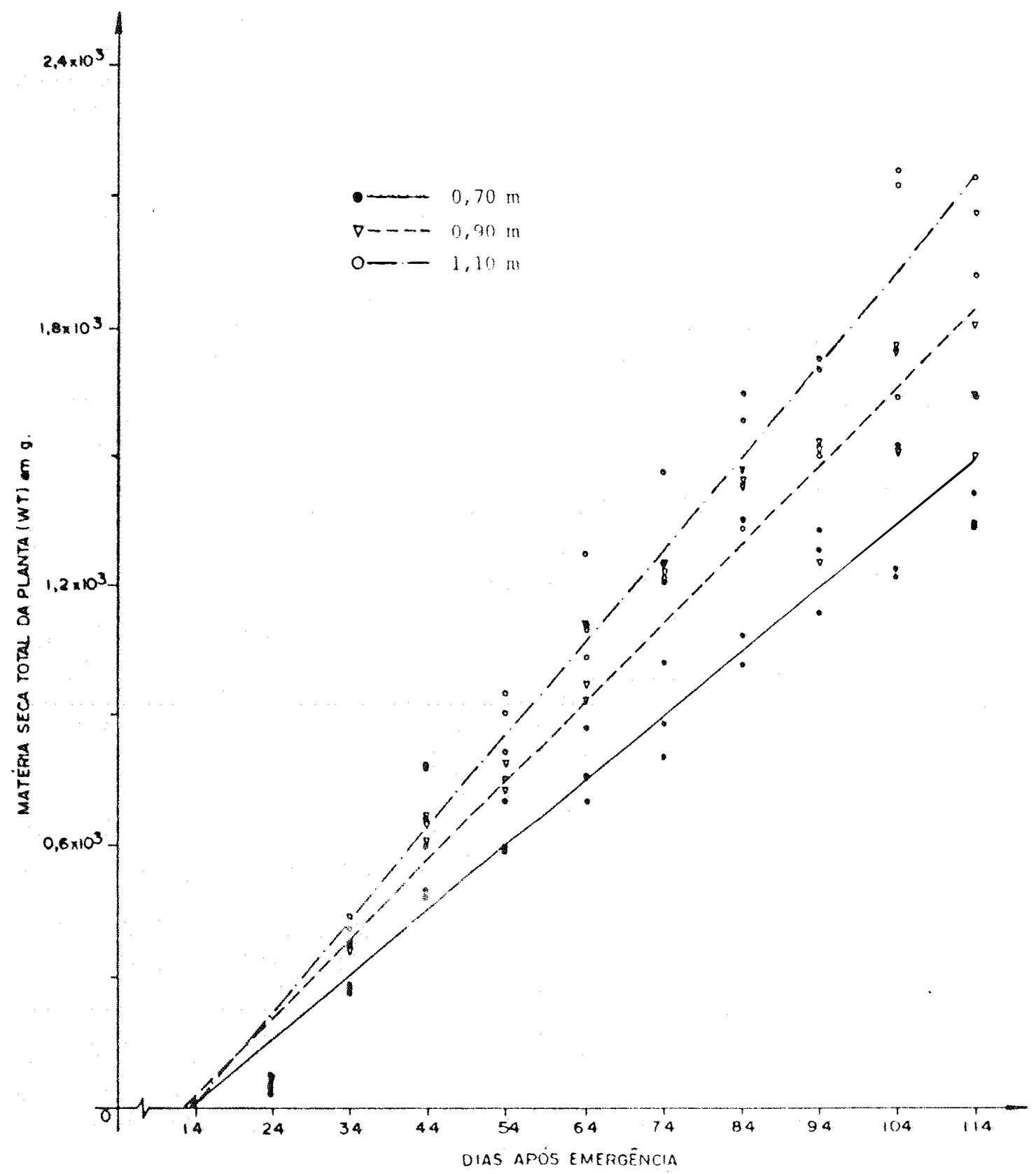

FIGURA 10 - Massa média de matéria seca total das plantas (Wt) em gramas, para o tratamento com subsolagem, nos diversos espaçamentos, em uma cultura de milho (Zea mays L.), durante o ciclo em dias após a energência $(t)$. 


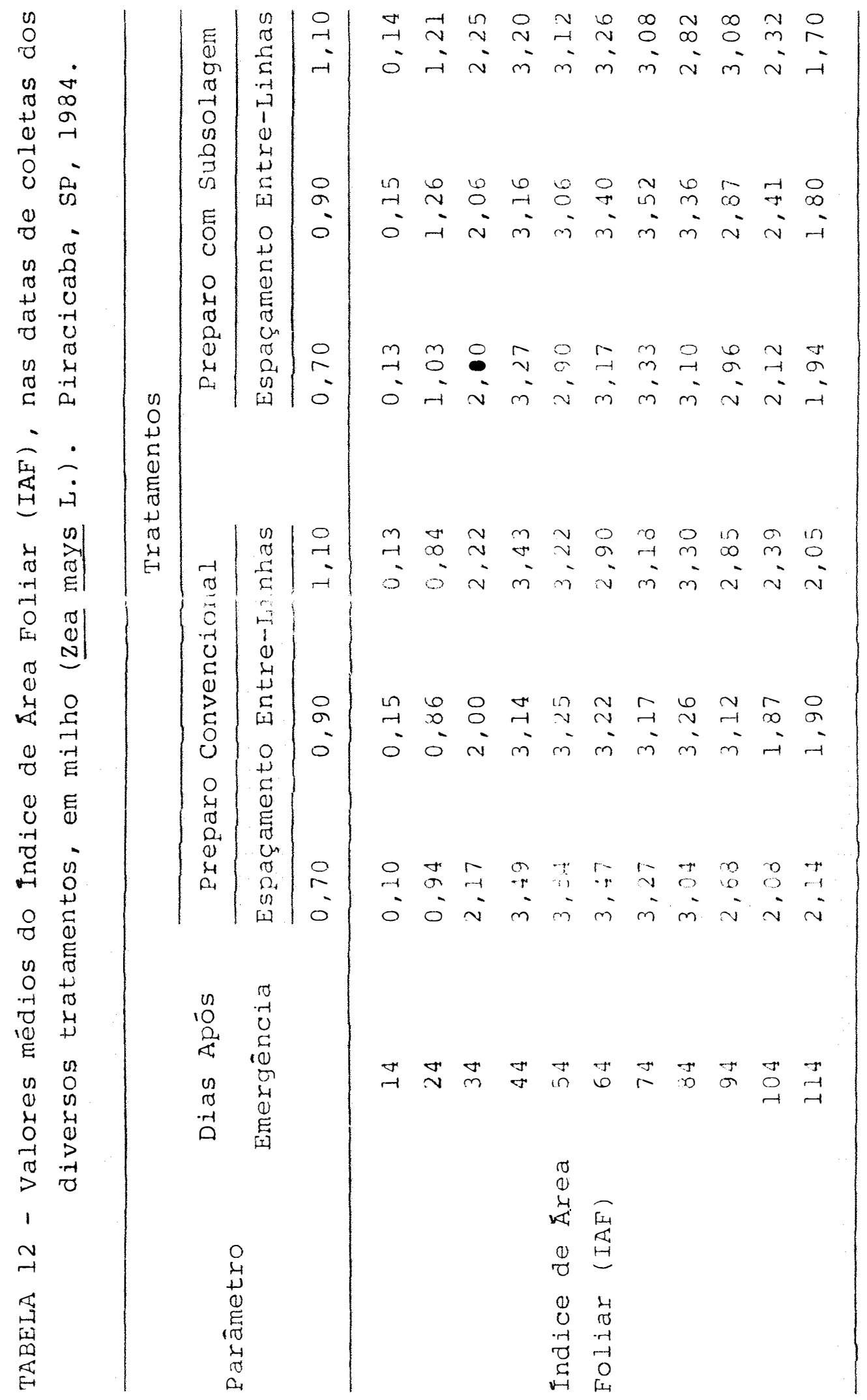




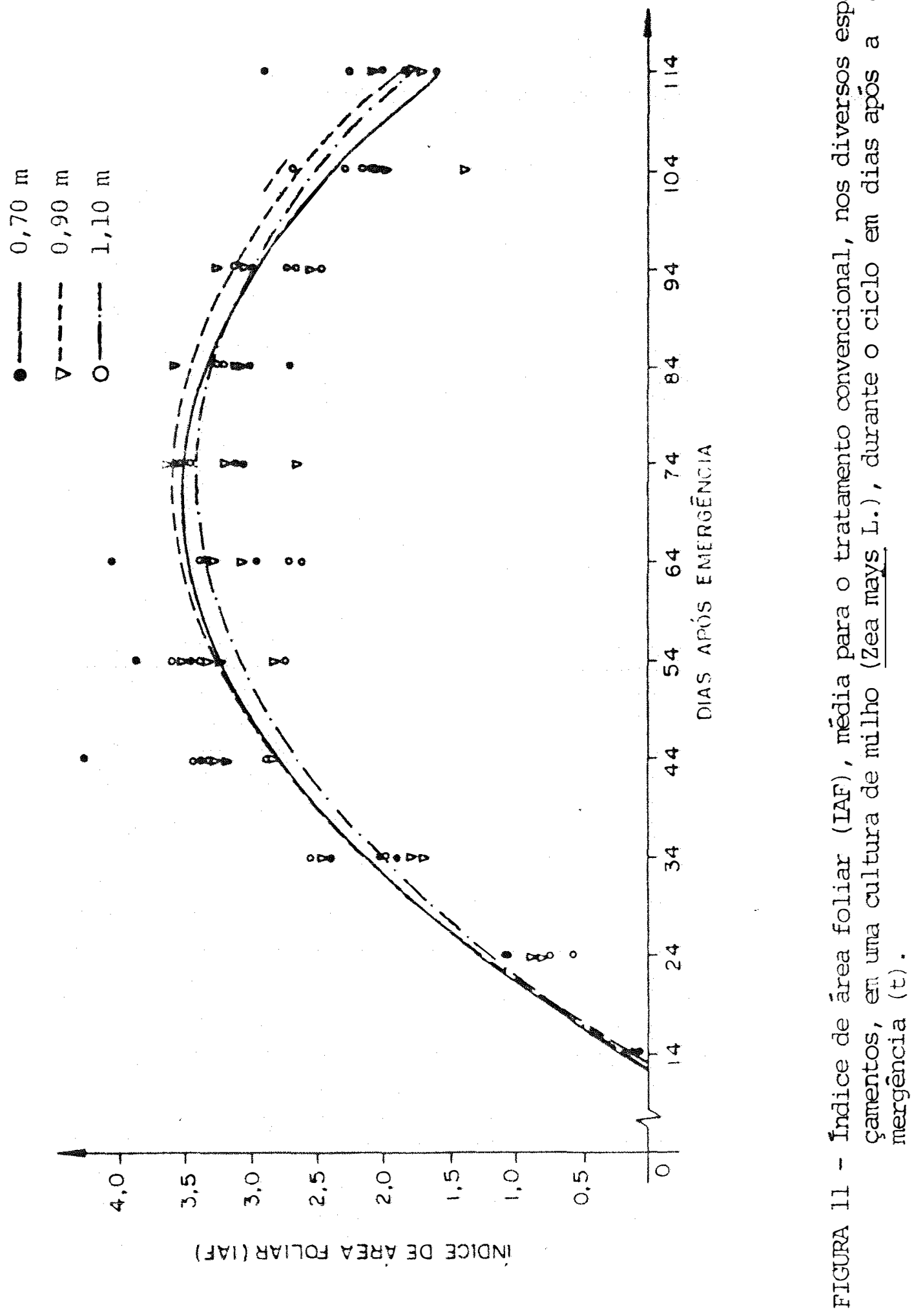




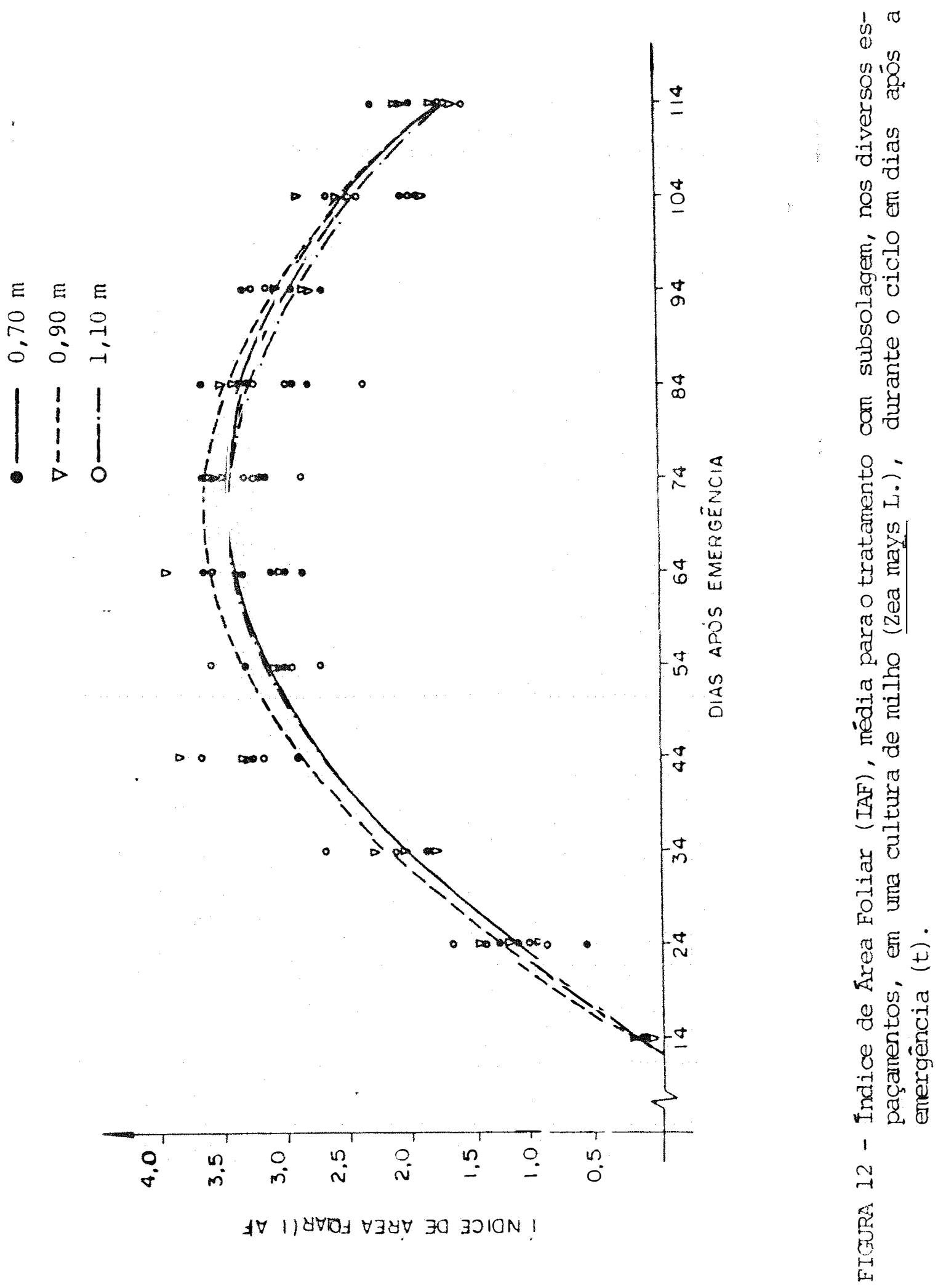


tos de $0,70,0,90$ e $1,10 \mathrm{~m}$.

Os coeficientes das equações que melhor se ajustaram para o IAF e os coeficientes de determinação encontram-se na Tabela 13.

\subsubsection{Produtividade biológica}

As curvas ajustadas da produtividade biológica (PB) com o tempo encontram-se nas Figuras 13 e 14, para os respectivos tratamentos estudados. Para o preparo do solo convencional, a maior produtividade biológica foi alcançą da aos 114 dias após a emergência, cujos valores foram de 1578,1, 1603,9 e $1645,9 \mathrm{~g} \cdot \mathrm{m}^{-2}$, nos espaçamentos de 0,70, 0,90 e $1,10 \mathrm{~m}$, respectivamente. No preparo do solo com subsolagem, para os mesmos espaçamentos, obtiveram-se valores de $1517,5, \quad 1503$ e $1575,1 \mathrm{~g} \cdot \mathrm{m}^{-2}$, aos 114 dias após cmergência.

Na Tabela 14, encontram-se os valores dos coe ficientes da equação de regressão e respectivos coeficientes de determinação $\left(R^{2}\right)$, parà os tratamentos. Os valores deste parämetro, para cada coleta, são apresentados na Tabela 15 . 


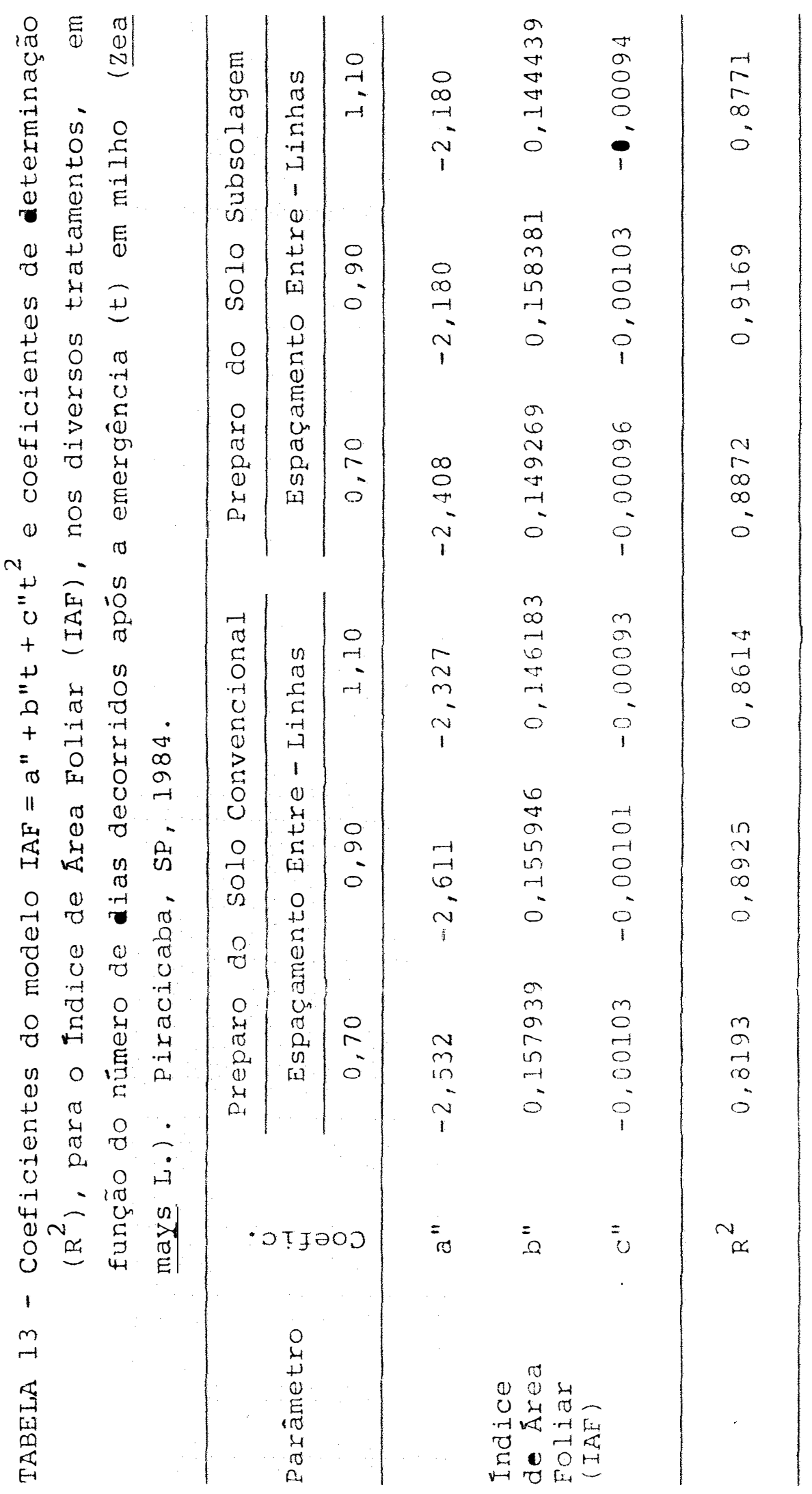




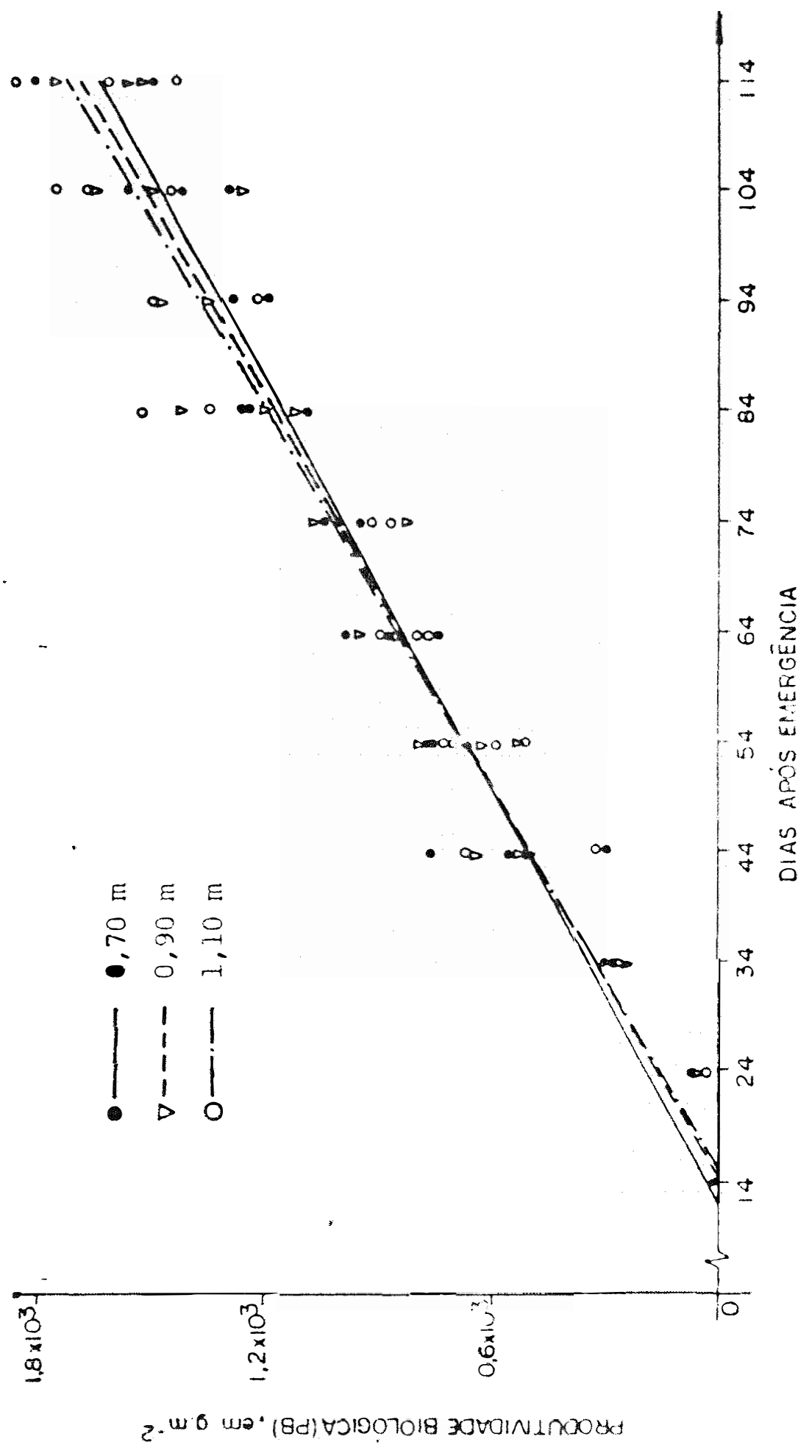

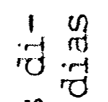

Оू E

त्रे

of 0

(1)

ट

8 号

$+$

ษ -

I

苛究

0 (

\%

2

옥

귤

E

$v-\frac{\theta}{0}$

1

E.

(i)

곡

ब्व

ชुํำ

葛的

O 8

लि

(1) है.

ơ

T.

$\rightarrow$ 垈

记

8 जा

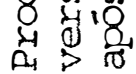

1

$\stackrel{m}{7}$

䔾 


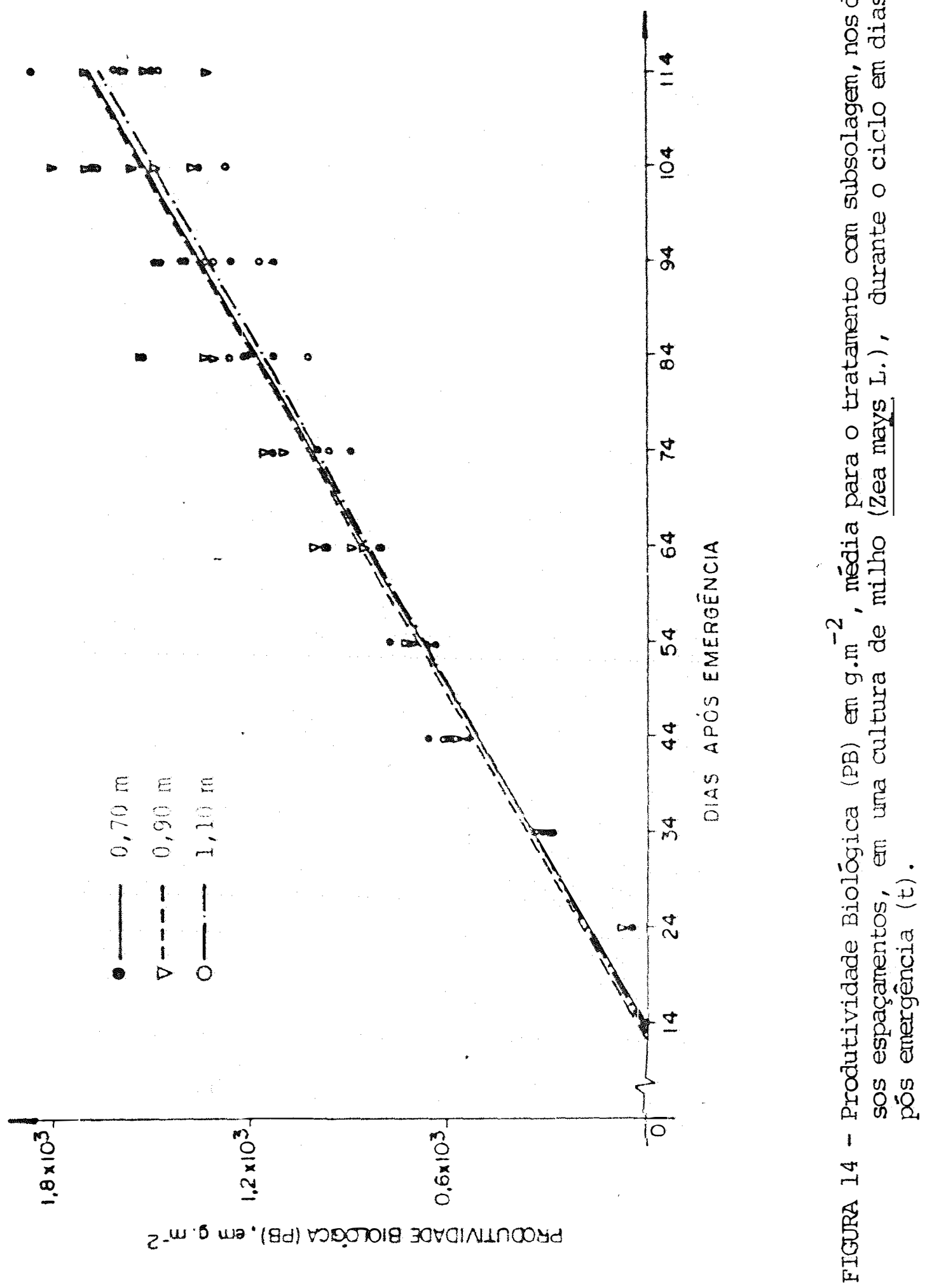




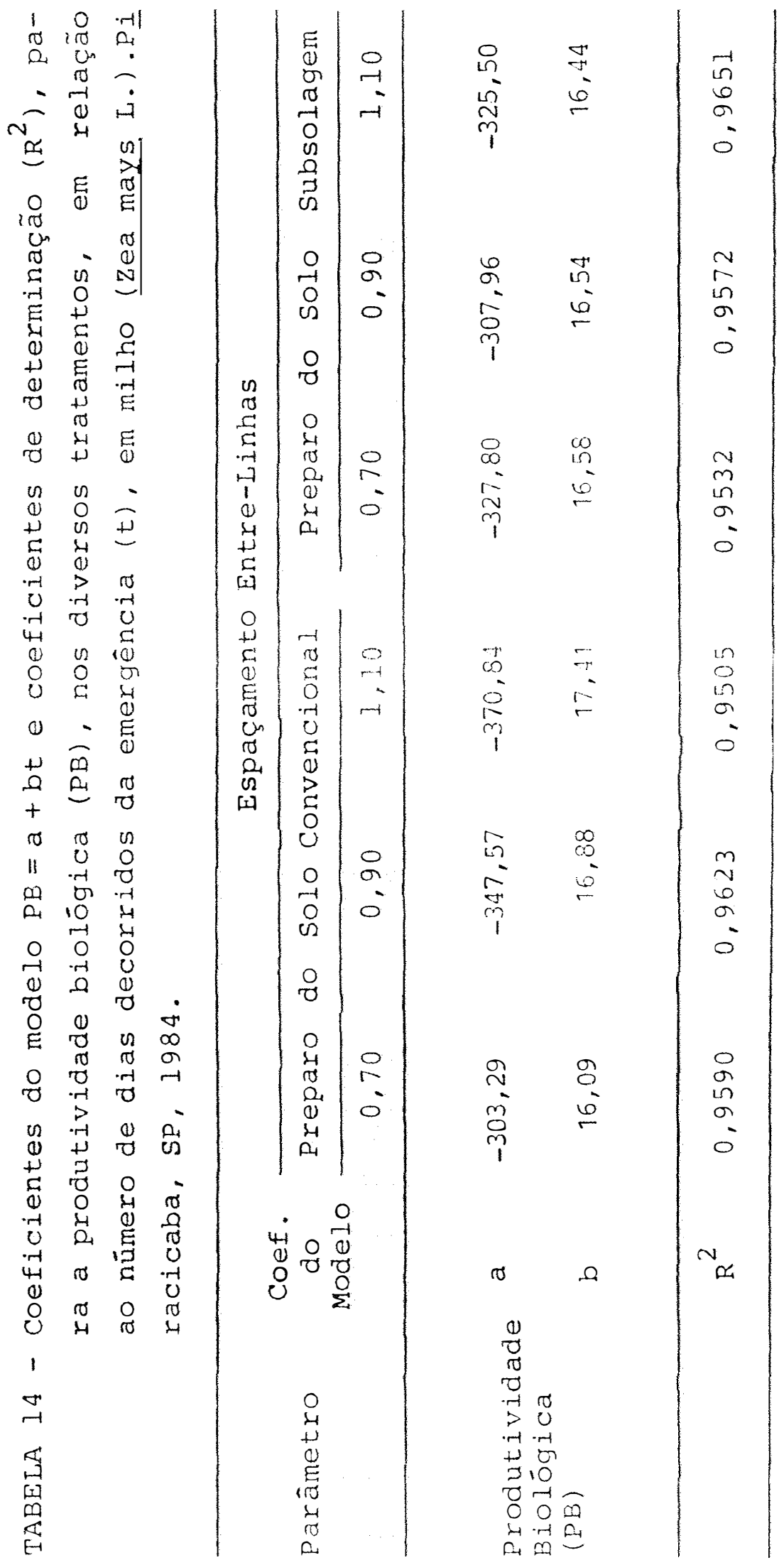




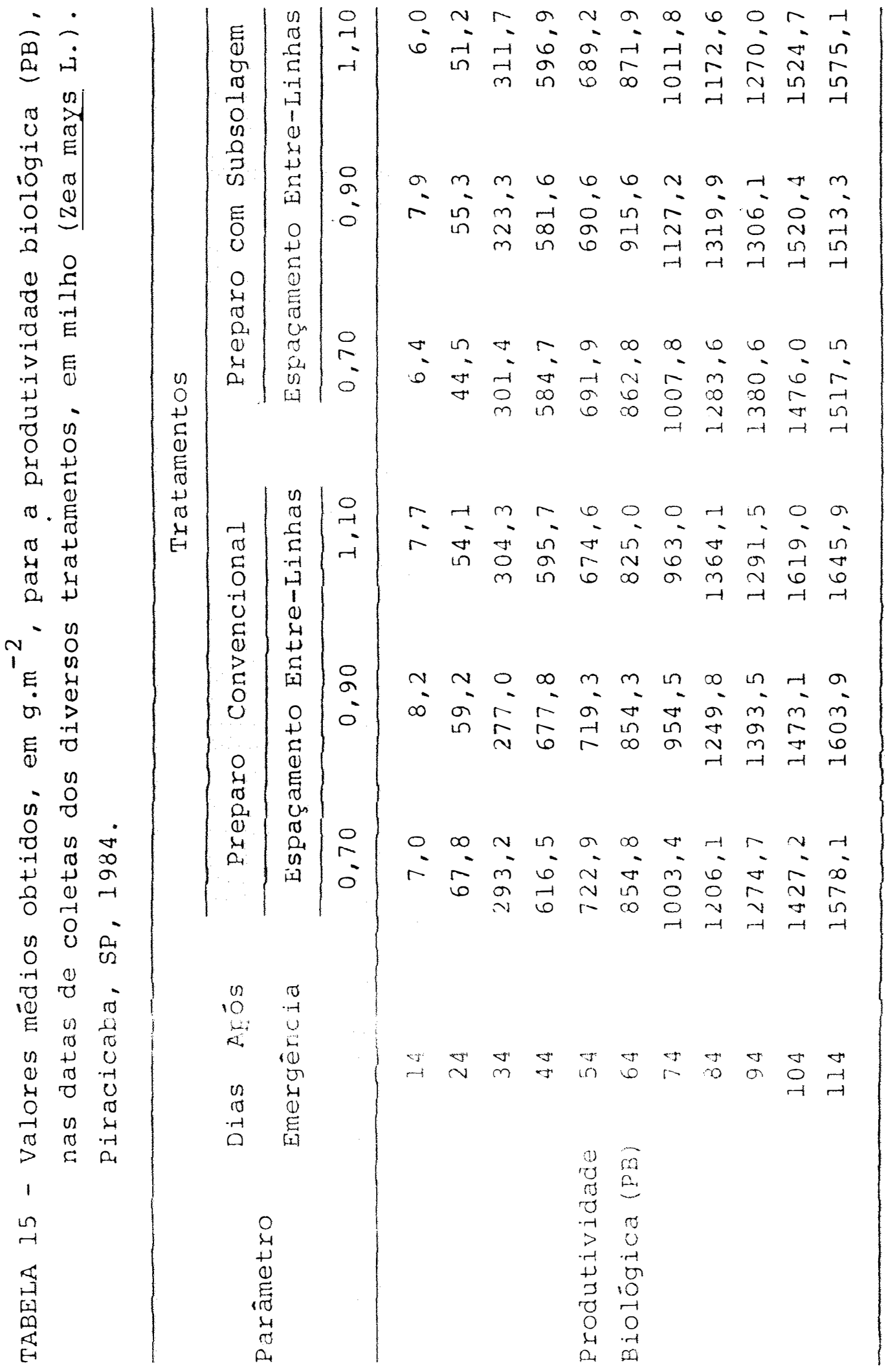




\subsubsection{Taxa de crescimento da cultura}

Nas Figuras 15 e 16 são mostrados os valores constantes de TCC calculados a partir da equação (2), os pontos experimentais calculados a partir dos dados da Tabela 15, por meio da equação

$$
\overline{\mathrm{TCC}}=\frac{\mathrm{PB}_{2}-\mathrm{PB}_{1}}{t_{2}-t_{1}}
$$

e a curva mëdia de todos os tratamentos traçada manualmente. Os valores constantes de TCC, calculados a partir da equação (2), valem: 16,09, $16,69 \mathrm{e} 17,49 \mathrm{~g} \cdot \mathrm{dm}^{-2} \cdot \mathrm{dia}^{-1}$, para o prepa ro do solo convencional, e $16,58,16,59$ e $16,44 \mathrm{~g} \cdot \mathrm{dm}^{-2} \cdot \mathrm{dia}^{-1}$ para o solo com subsolagem, nos espaçamentos $0,70, \quad 0,90$ e $1,10 \mathrm{~m}$, respectivamente. A equaçäo (1.2), utilizada para o cálculo da Taxa de Crescimento da Cultura Média, é deduzida a partir da integração da equação (2), no intervalo de tempo $t_{2}-t_{1}$

\subsubsection{Taxa de crescimento Relativo}

As curvas da taxa de crescimento relativo, em $\mathrm{g} \cdot \mathrm{g}^{-1} \cdot \mathrm{dia}^{-1}$, ao longo do ciclo da cultura, elaboradas a partir da equação (5), encontram-se nas figuras 17 e 18, para os dois preparos do solo (convencional e subsolagem) e os três espaçamentos entre-linhas $(0,70,0,90 \mathrm{e} 1,10 \mathrm{~m})$, respectivamente. Os pontos mostrados nas Figuras 17 e 18 foram cal- 


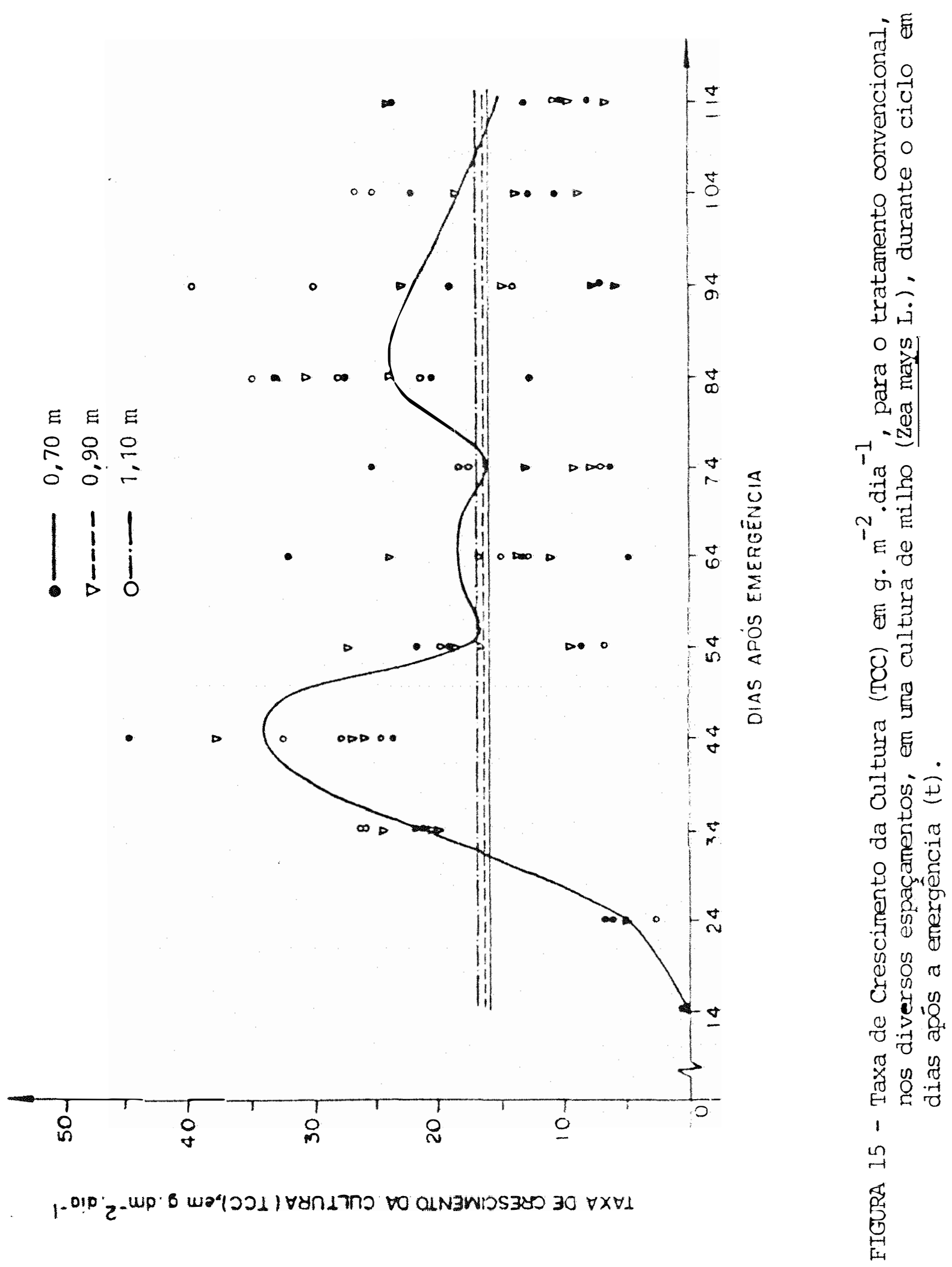




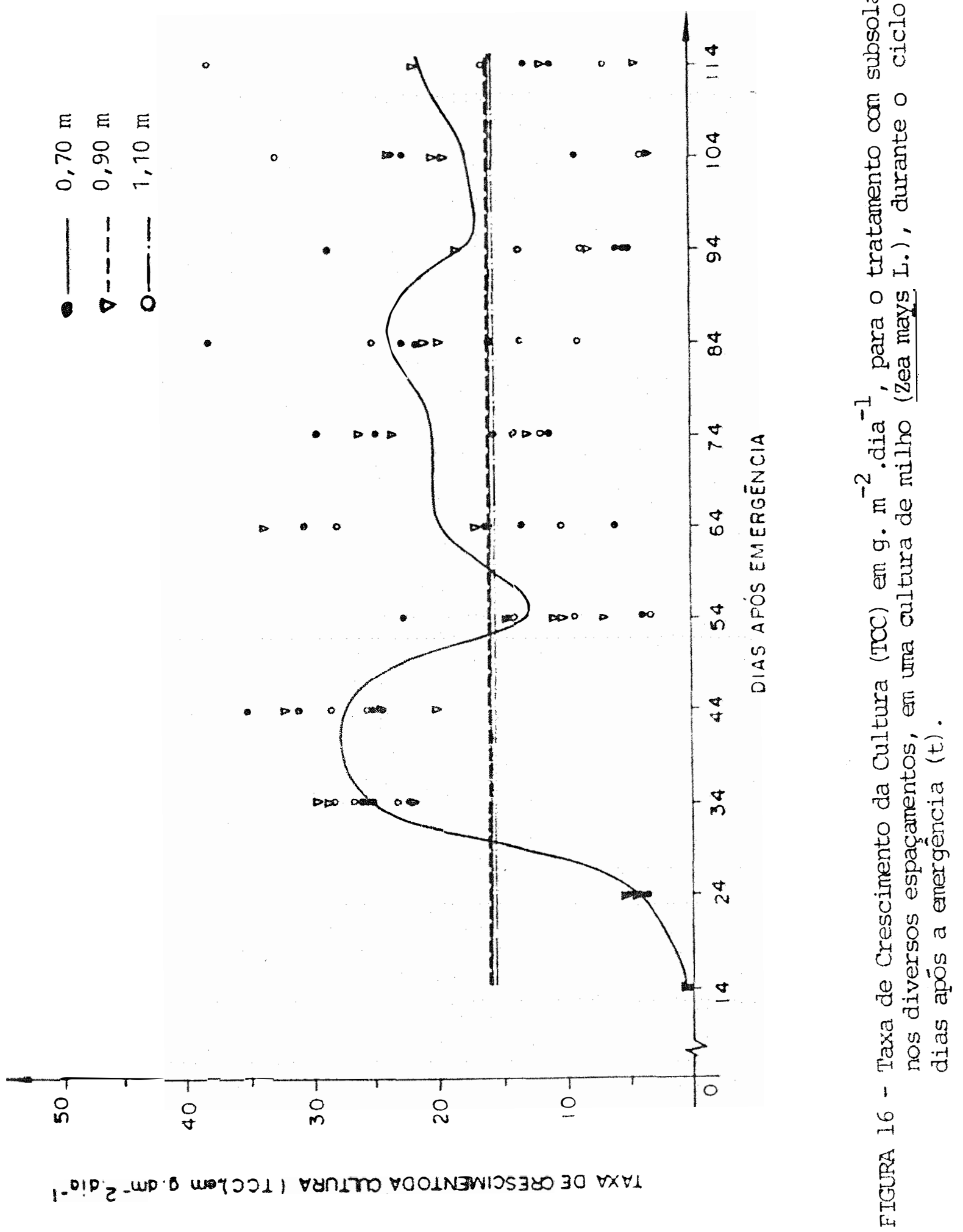




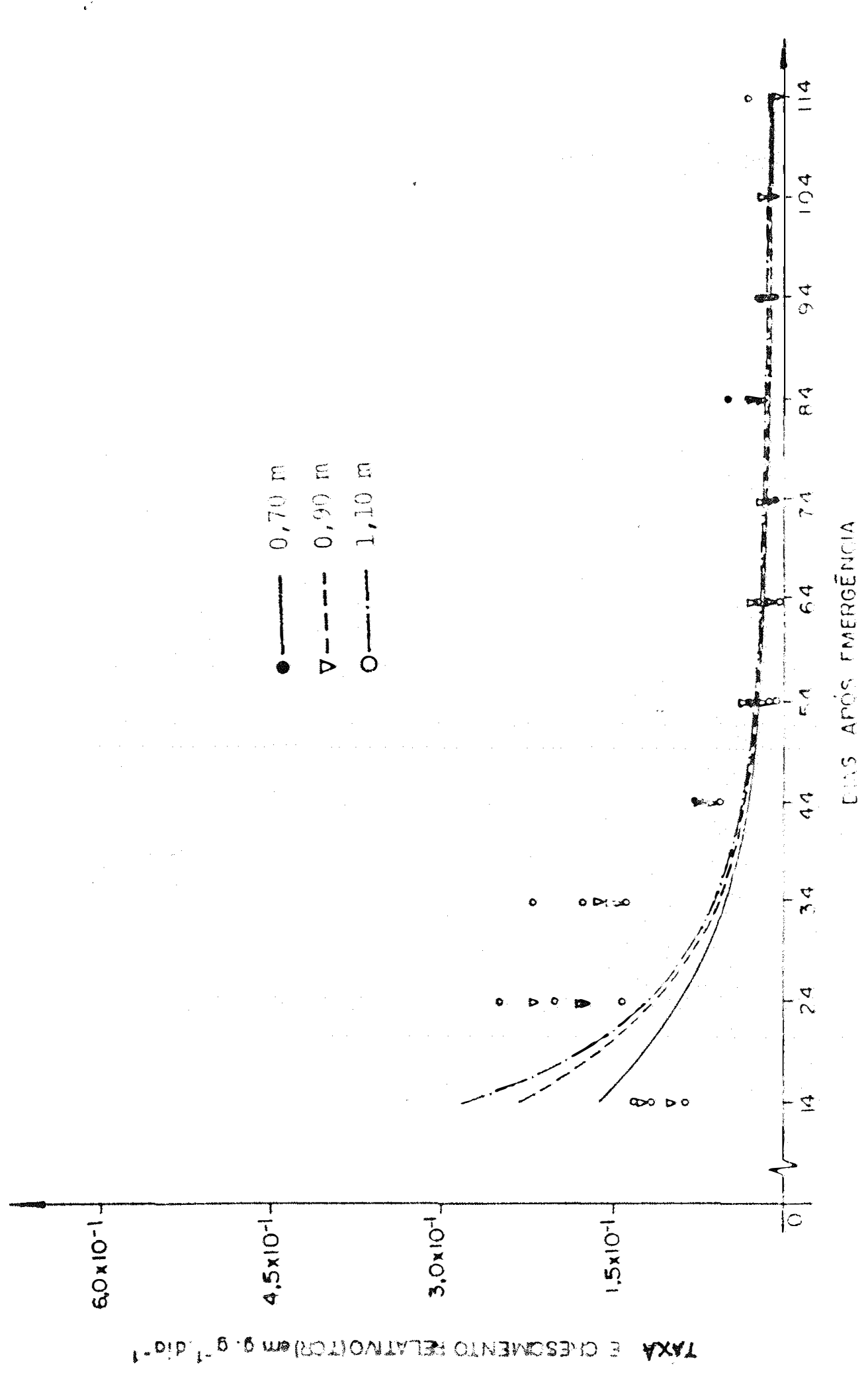

o 굴엄 o 일 蒝 도 范 等 耑

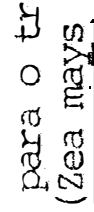
(t) 然 Tे 담 To or छำ ๔ี हี E 自 可舟立

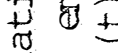
D $=\pi$ थ 0 要造 \& 대을 08 o in $\pi$ 0 . of of o $x>\pi$

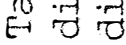
ㄱ-1 采 (5) 


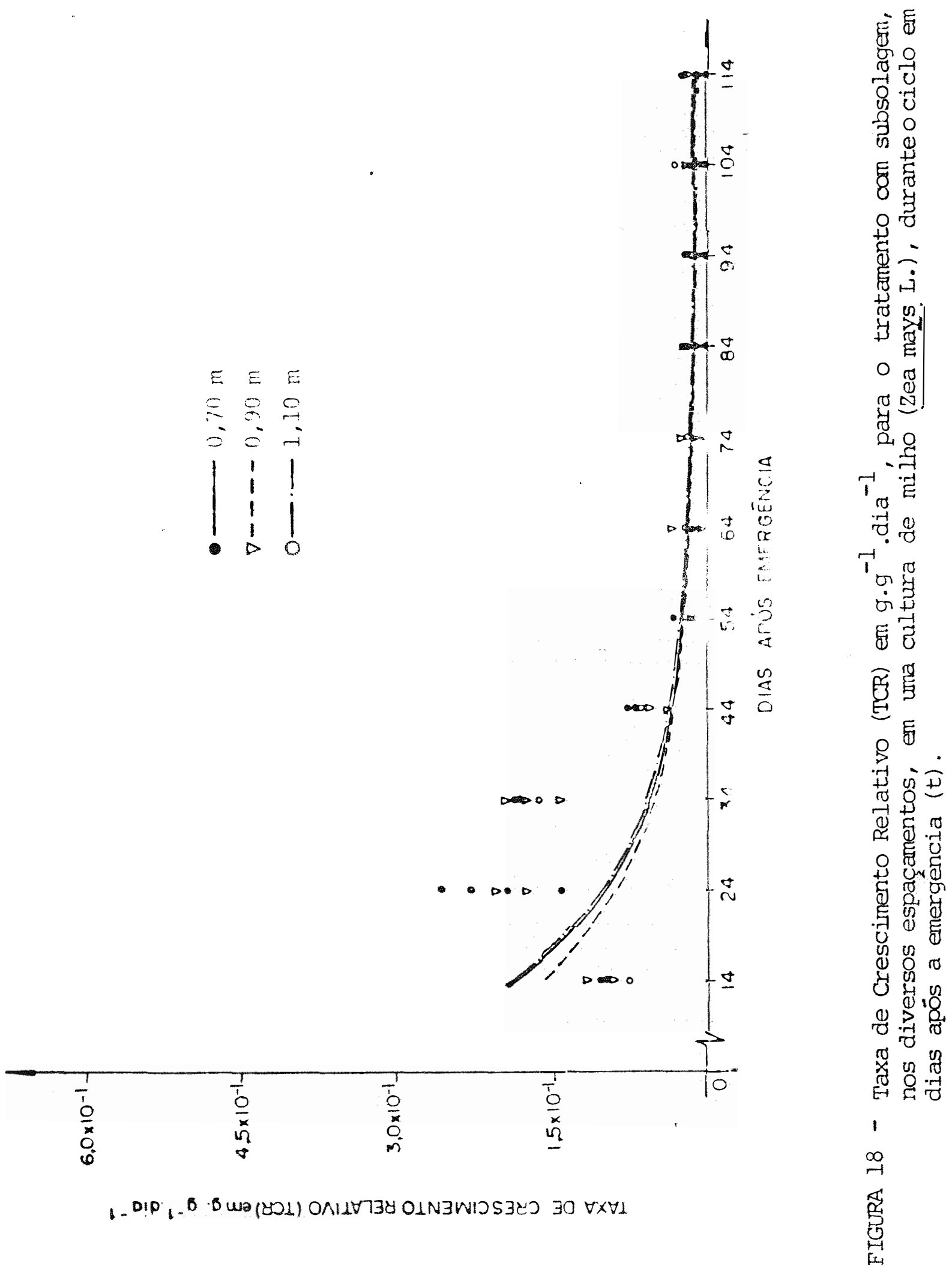


culados a partir dos dados da Tabela 15, por meio da equação

$$
\overline{\mathrm{TCR}}=\frac{\ln \mathrm{PB}_{2}-\ln \mathrm{PB}_{1}}{t_{2}-t_{1}}
$$

deduzida a partir da integração da equação (4), no intervalo de tempo $t_{2}-t_{1}$, representando, portanto, o valor médio de TCR nesse intervalo.

4.5.5. Taxa de Assimilação Lịuida

A partir da equação (8), elaboraram-se as cur vas de TAL versus t. As Figuras 19 e 20 apresentam tais cur vas para o preparo do solo convencional e o preparo com subsolagem, e para os três espaçamentos entre-1inhas 10,70 , 0,90 e $1,10 \mathrm{~m}$, respectivamente.

\subsubsection{Razão de Ârea Foliar}

A partir das Tabelas 12 e 15 , que apresentam os dados experimentais de IAF e PB, respectivamente, elabora ram-se as curvas da razão de área foliar, ao longo do ciclo da cultura, de acordo com sua definição (equação 9). Estes valores, para os tratamentos convencional e com subsolagem, nos respectivos espaçamentos, encontram-se nas Figuras 21 e 22. Os pontos experimentais destas duas figuras foram obtidos a partir dos dados das labclas 12 o 15 , pela aplicaça da 


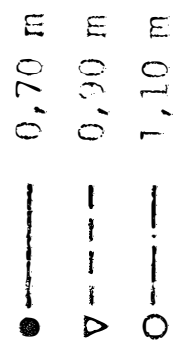

음

호토

잉

언

बै

80

菏

究

ㄱ.

穷

廿⿻

空

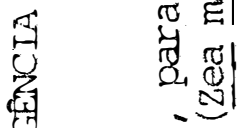

1 \%

ह

if

Бี

$\dot{\sigma}$

告

ธี

3

鱼

空

然的金

요용

(8)

$\rightarrow$ 每

है.

oै प्रे

क ज

of $\begin{array}{ll}0 \\ 0\end{array}$

त के

\%

每学

1

ब्न

莺

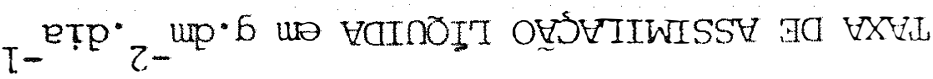




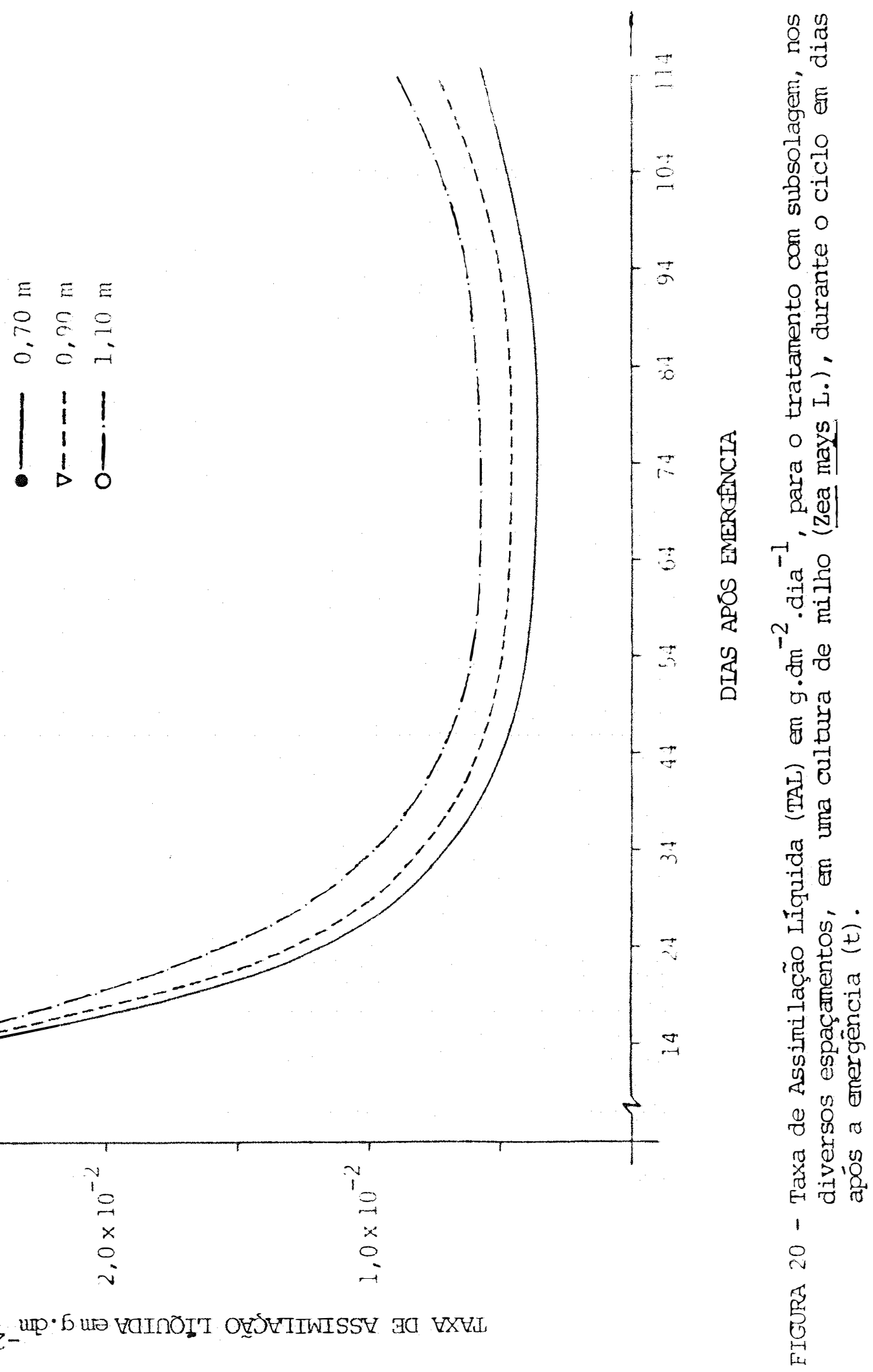




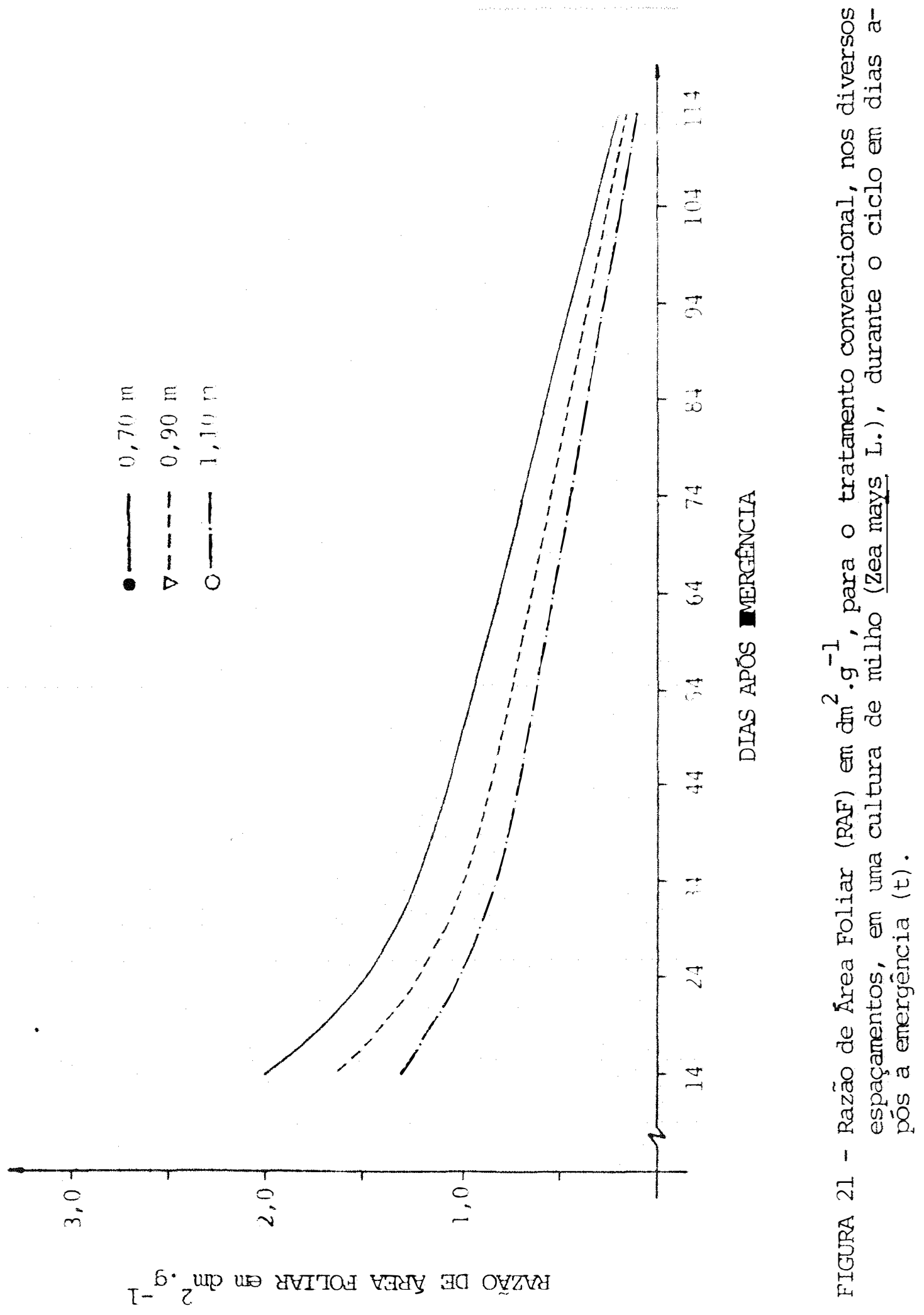




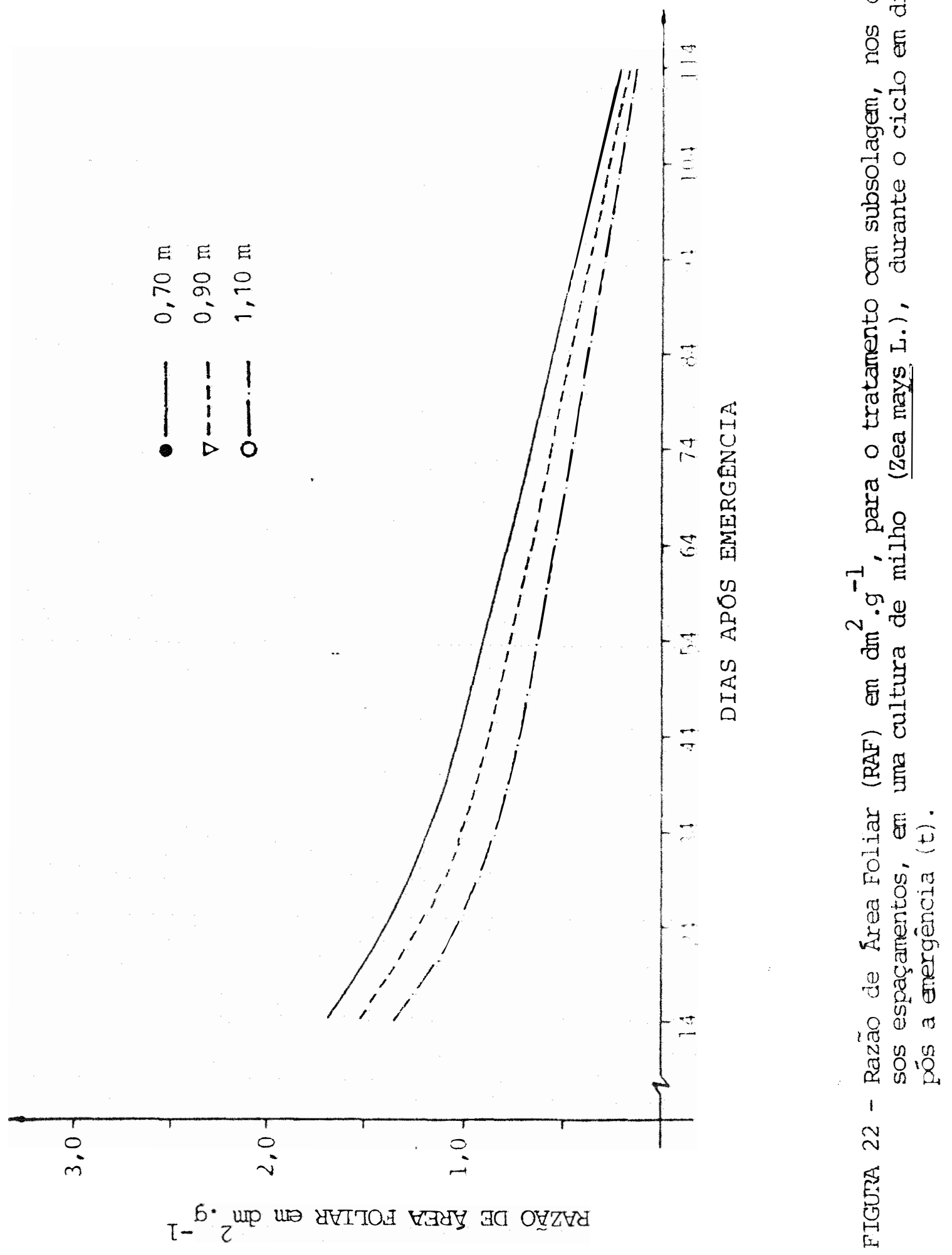


equação (9) e encontram-se dispostos na Tabela 16, em cada tem po correspondente. As curvas de regressão da razão de área foliar, foram realizadas a partir da equação (11). Os maio res valores da razão de ärea foliar alcançados para os espaçamentos de $0,70,0,90$ e $1,10 \mathrm{~m}$, no preparo convencional, foram de $1,39,1,80 \mathrm{e} 1,64 \mathrm{dm}^{2} \cdot \mathrm{g}^{-1}$ aos 14 dias após emergência. Para o preparo com, subsolagem, obtiveram-se valo res máximos de $2,30,2,30$ e $2,43 \mathrm{dm}^{2} \cdot \mathrm{g}^{-1}$ aos 14 dias após a emergência.

\subsection{Produção por ärea}

A produção de grãos alcançou valores de 7836 , 8242 e $10068 \mathrm{~kg} / \mathrm{ha}$, para o preparo do solo convencional, nos espaçamentos de $0,70,0,90$ e $1,10 \mathrm{~m}$, respectivamente. O pre paro do solo com subsolagem, nos respectivos espaçamentos, a presentou os seguintes resultados de massa de grãos por hectare: 7933, 8780 e $10421 \mathrm{~kg} / \mathrm{ha}$. As massas de grãos, massas de espigas sem palha e as massas de sabugo ('Tabela 17) fo ram obtidas com umidade de $20 \%$ 


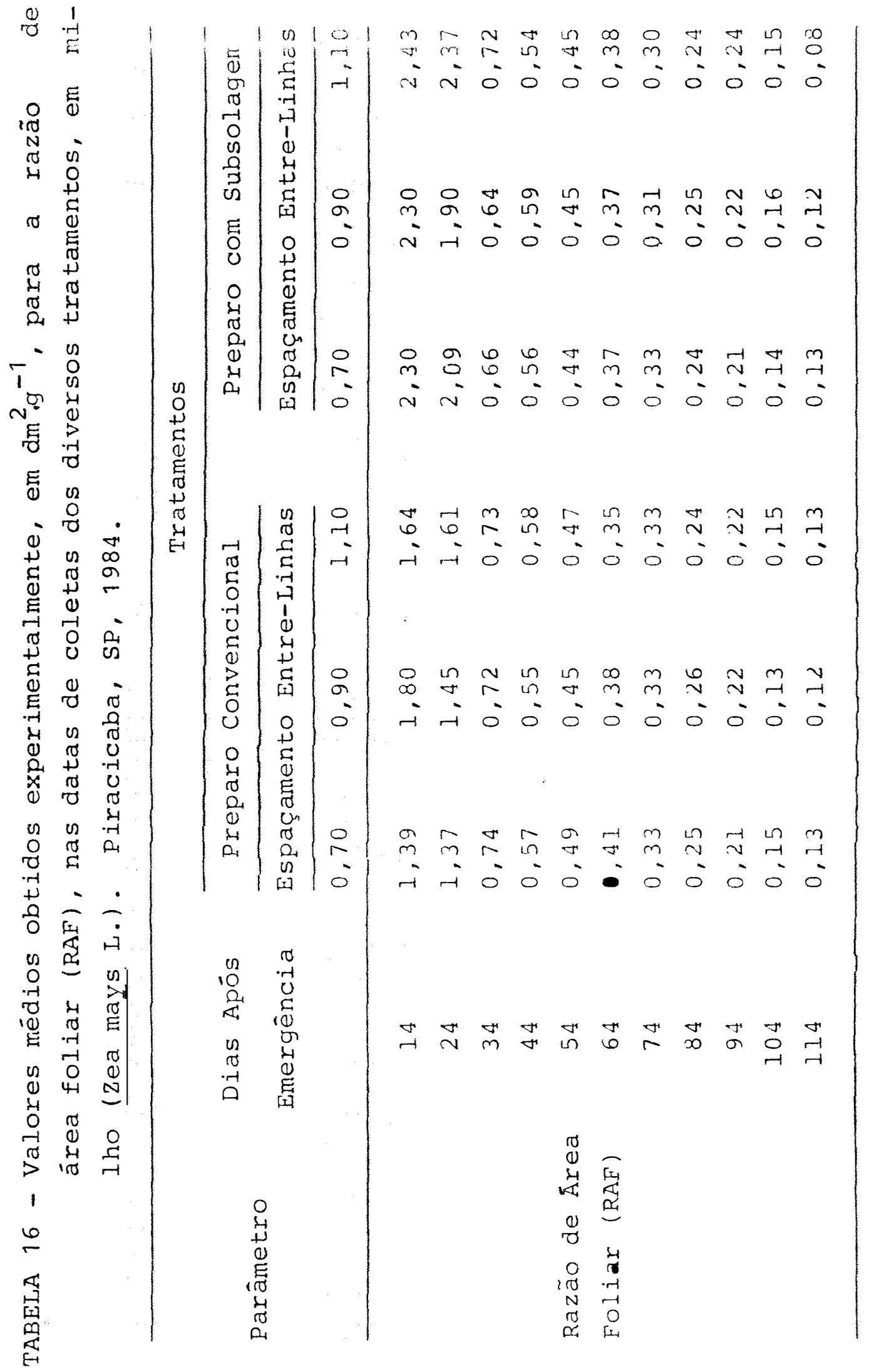




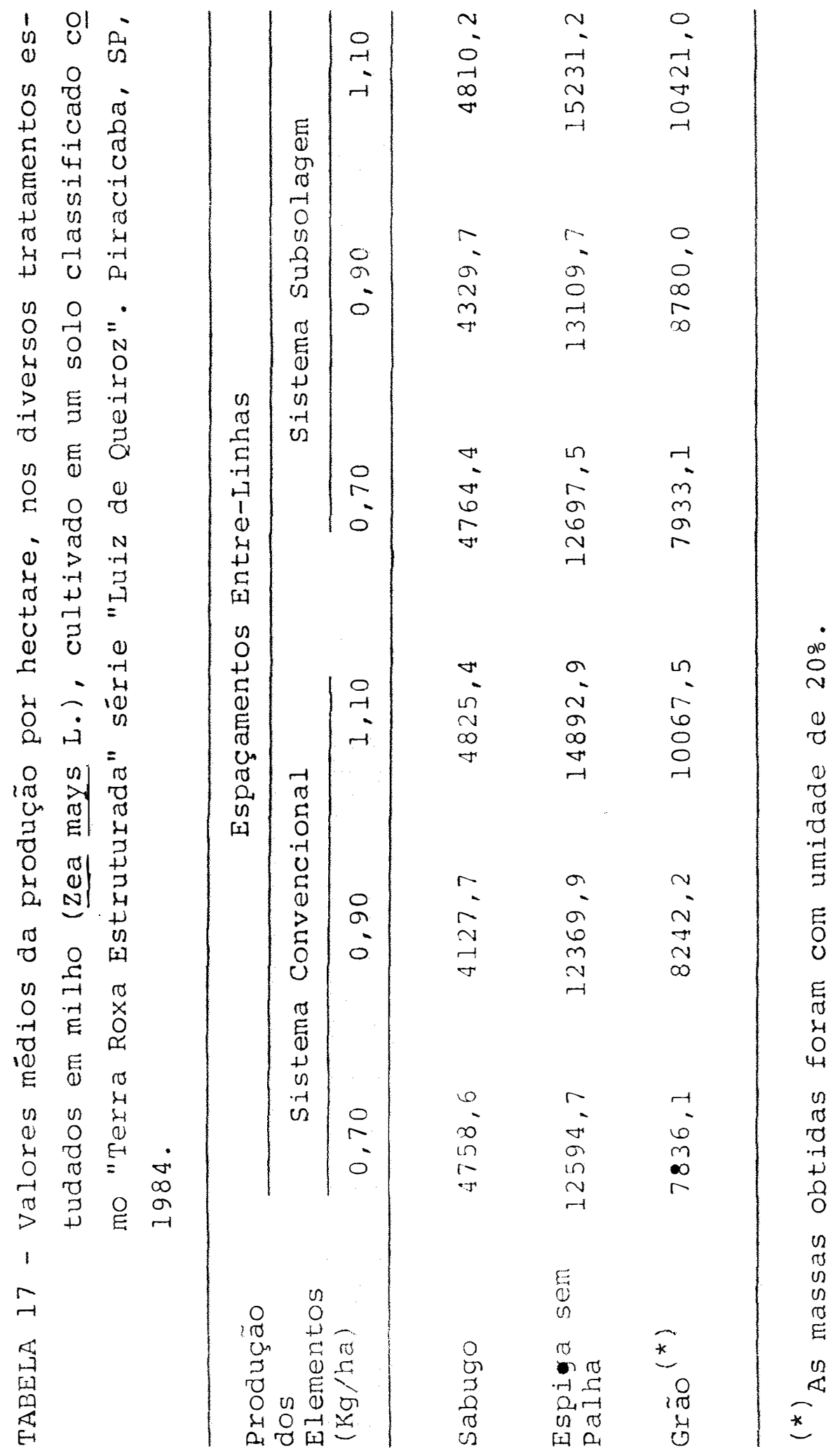




\section{DISCUSSÃO}

5.1. Radiação solar e precipitação

Observa-se, pela Figura 3 , que a radiação solar global durante o período da cultura teve um comportamento decrescente e oscilante. O decrëscimo é normal em função dos meses do ano. As oscilações, por outro lado, são devidas à nebulosidade que, segundo LOOMIS e WILLIAMS (1963), acarretam uma utilização näo satisfatöria de luz pela planta de milho, que deve resultạ numa redução da produção de maté ria seca. Apesar disso, em termos quantitativos, a radiação solar foi suficiente para um bom desenvolvimento da cultura, embora tenha havido diminuição da fotossintese em decorrēncia da nebulosidade.

Com relação à precipitação mostrada na Figura 3, pode-se verificar que até certo ponto foi bem distribu ía, mas a sua quantidade muito baixa lo valor máximo obtido 
não atingiu $15 \mathrm{~mm}$ ). Isto se refletiu num total de precipita ção $(136,2 \mathrm{~mm})$ inferior à média do local para o período considerado, e também inferior àquele preconizado por CANECHIO FILHO et alii (1973), necessários à cultura do milho e que, por conseguinte, exigiu a suplementação de ãgua por irrigação, principalmente nas épocas de floração e polinização.

\subsection{Matéria seca}

Analisando os dados de matéria seca dos colmos, folhas e total, para os tratamentos convencional e com subsolagem, constantes das Tabelas 7 e 8 , respectivamente,pa ra os três espaçamentos utilizados, e os de produção por área, constantes da Tabela 17, pode-se verificar que para estes parâmetros, a operação de subsolagem não causou praticamente nenhuma variação em relação ao preparo convencional. Esta afirmativa pode ser melhor visualizada nos gráficos das Figuras 4 a 10 , nos quais uma análise conjunta do comportamento dos tratamentos convencional e com subsolagem, indica uma coincidência quase que perfeita das curvas. As curvas apresentadas nessas figuras (4 a l0) foram obtidas por regressões lineares (Figuras 4, 5, 9 e 10) e quadráticas (Figu ras 6,7 e 8 ). Os coeficientes das equações representativas obtidas por estas regressões, assim como seus respectivos co eficientes de determinação podem ser vistos nas l'abelas 9, 10 e 11, através das quais observa-se que o ajuste das curvas 
aos pontos experimentais foi bastante satisfatório, com o $R$ sempre maior que 0,9 . Fato importante a salientar é o da ta xa constante da massa dos colmos (Figuras 4 e 5), pois não se verifica uma diminuição no valor deste parâmetro após o 1059 dia da emergência, conforme salientam LOPES e MAESTRI (1973). Isto se deve ao fato de que, neste trabalho, desde o início da formação de espigas, estas foram adicionadas às massas dos colmos.

A não influência da subsolagem encontrada no presente experimento pode ser devida ao fato da cultura ter sido irrigada no decorrer do ciclo, o que, evidentemente, evitou a ocorrēncia de déficit hídrico, ofuscando, portanto, o contraste entre os tratamentos. Com relação à influēncia dos espaçamentos estudados na produção, verifica-se, através da Tabela 17, aumento da produção com o aumento do espaçamen to, tanto para o sistema convencional como para o com subsolagem. O maior valor obtido no espaçamento 1,10 $\mathrm{m}$ entre-linhas, provavelmente, foi ocasionado pela melhor utilização da energia solar através do dossel de plantas, devido a uma melhor distribuição de luz nas suas camadas pelo maior afastamento entre-linhas. O outro fator que poderia contribuir para esta diferença seria a āgua, mas esta foi controlada, conforme já esclarecido anteriormente. Comportamento semethante à produção também foi encontrado para os outros parâmetros das Tabelas 7 e 8 e Piguras 4 a 10, isto 0 , om média, 
as massas de matéria seca do colmo e das folhas de uma planta, e da planta inteira, foram crescentes com o aumento do espaçamento.

\subsection{Caracteristicas morfológicas}

Fazendo-se uma análise comparativa dos tratamentos convencional e com subsolagem das alturas de plantas e número de espigas por planta (Tabelas 2 e 3 ), é fácil de perceber que praticamente não houve diferença nos resultados obtidos. Informação semelhante pode ser extraída destas tabelas quando se comparam os diversos espaçamentos utilizados. o padrão de desenvolvimento deste cultivar de milho, notadamente no que diz respeito ao número de folhas por planta,foi aquele que se esperava quanto às suas caracteristicas. Ver fica-se, pelas Tabelas 2 e 3, que o número máximo de folhas coincide com a fase final do estádio vegetativo, isto é, aos 52 dias após a emergência em todos os tratamentos. Quando à caracteristica morfológica, número de espigas por planta, tam bém não houve praticamente influência nem da subsolageme nem dos espaçamentos, muito embora com relaçäo aos espaçamentos percebe-se uma leve tendência de aumento do número de espigas por planta com o aumento do espaçamento. 
5.4. Fenologia

A partir dos dados da Tabela 5, elaboradas de acordo com o descrito por HANWAY (1963), para o presente experimento, verifica-se que comparativamente, todos os tratamentos, tanto os de preparo do solo como os de espaçamento, apresentaram períodos fenológicos semelhantes. Estes resultados mostram também que para este cultivar de milho, não hou ve influência da época de semeadura, uma vez que esta foi efetuada dia 7 de fevereiro de 1984, portanto, muito tardiamente.

\subsection{Anälise de raỉzes}

As coletas dos monólitos de solo mais raỉzes do perfil do solo foram realizadas no dia 18 de abril, próxi mas ao início do estádio reprodutivo (Tabela 5), correspondendo ao 719 dia após a semeadura. A distribuição das raízes nos perfis de solo subsolado e não subsolado encontra-se na Tabela 6. Observa-se, por esta tabela, que a profundidade máxima atingida pelo sistema radicular no preparo do solo convencional foi de $1,71 \mathrm{~m}$. Entretanto, 90,9\% do seu volume foi encontrado nos primeiros $60 \mathrm{~cm}$ do solo. Na camada de so 10 entre as profundidades 20 e $40 \mathrm{~cm}$ jā havia $44,2 \%$, e nos primeiros $20 \mathrm{~cm}$, cerca de 4,7\% do total. O sistema radicular do preparo do solo com subsolagem atingiu a profundida 
de máxima de $1,99 \mathrm{~m}$. Nos primeiros $60 \mathrm{~cm}$, obteve-se ovalor $87,3 \%$ do total das raízes; a $40 \mathrm{~cm}, 14,6 \%$ e até $20 \mathrm{~cm}, 5,6$ 응 do total. As massas totais de raizes foram de 618,1 g no pre paro do solo convencional e 506,2 g no preparo do solo com subsolagem. O sistema radicular do preparo convencional apresentou maior massa total, mas atingiu menor profundidade, enquanto o preparo com subsolagem, ao contrário, apresentou menor massa de raizes e um sistema radicular um pouco mais profundo. Até a profundidade de $1 \mathrm{~m}$, ambos os tratamentos apresentaram boas massas de raỉzes, porém, o preparo convencional mostrou, nas camadas até $40 \mathrm{~cm}$, maior massa de raízes que o preparo com subsolagem, o inverso ocorrendo nas profun didades maiores. Estes resultados divergem um pouco dos obtidos por CRUZ e TAMES (1972) e MENGEL e BARBER (1974), por serem valores mais elevados, mas se aproximam daqueles obtidos por ESPINOZA (1982). Segundo este autor, a distribuição em massa de raỉzes mostrou uma concentração de 60 a $80 \%$ nas primeiras camadas do perfil do solo e, a partirdos $40 \mathrm{~cm}$, a porcentagem diminui ate 10 a $15 \%$.

\subsection{Parâmetros fisiológicos}

Conforme já comentado no item 3.7 , o parâmetro produtividade biológica ao longo do ciclo da cultura, no pre sente experimento, teve um acréscimo linear no tempo para to 
dos os tratamentos utilizados, isto é, preparo do solo convencional, preparo do solo com subsolagem e espaçamentos de $0,70,0,90$ e $1,10 \mathrm{~m}$. Esta relação linear pode ser visualizada nos gráficos das Figuras 13 e 14 , para os tratamentos convencional e com subsolagem, respectivamente. Observa-se por estas figuras, que o ajuste das curvas aos pontos experi mentais foi satisfatório, mostrando que a produtividade biológica variou linearmente com o tempo no presente caso. Isto é confirmado pelos altos valores dos cooficientes de determi nação $\left(R^{2}\right)$ que foram sempre maiores que 0,95 , conforme mostra a Tabela 14, na qual também se encontram dispostos os coe ficientes linear e angular das respectivas retas. Analisando separadamente as Figuras 13 e 14, verifica-se que, independente do tipo de preparo do solo, praticamente não houve dife rença no comportamento da produtividade biológica ao longo do tempo para os três espaçamentos estudados. Ao se analisar comparativamente estas figuras, verifica-se que este parâmetro não mostrou diferença de comportamento quando o preparo de solo foi convencional ou com subsolagem. Apesar de, via de regra, esta curva de $\mathrm{PB} \times \mathrm{t}$ apresentar a forma de uma si $\underline{\underline{g}}$ móide, mostrada por diversos trabalhos da literatura, como por exemplo, os de LOPES e LOPES (1977) e MACHADO et alii (1982), no presente caso isto não foi verificado, como bem atestam as Figuras 13 e 14, provavelmente pelo fato da última coleta de plantas (114 dias após emergēncia) ter sido efe tuada antes da maturação fisiológica do milho. Portanto, o 
comportamento decrescente da produtividade biológica não pôde ser verificado, e a regressão linear ter sido suficiente. o contrário ocorreu com o indice de área foliar, que aumentou com o tempo, atingiu um máximo, e depois decaiu até a úl tima coleta de plantas, devido à senescência das folhas. Es te comportamento do Indice de área foliar foi quadrático com - tempo, conforme mostram as Figuras 11 e 12, para os tratamentos de preparo do solo convencional e com subsolagem, res pectivamente. Tambëm neste caso, praticamente não houve diferença entre os diversos tratamentos, isto é, nem a subsola gem e nem o espaçamento influiram no comportamento deste parâmetro ao longo do ciclo da cultura. Com relação ao ajuste dos pontos experimentais a uma equação do segundo grau, neste caso, também foi satisfatório, uma vez que os valores de $R$ foram sempre maiores que 0,9, conforme pode ser vistona Ta bela 13, que mostra também os coeficientes da equação para os diversos tratamentos, obtidos pela regressão. Apesar das curvas apresentadas nas figuras 11 e 12 mostrarem um ünićo ponto de mäximo, ao redor do 758 dia após a emergência, analisando os dados realmente obtidos (Tabela 12), verifica-se uma diferença entre os tratamentos de preparo do solo conven cional e com subsolagem, isto é, como já salientado no item 4.1, no preparo de solo convencional, o valor máximo médio de IAF foi aos 64 dias após a emergência, enquanto que, no preparo com subsolagem aos 74 dias apös a emergência. Este comportamento quadrático do IAF ao longo do ciclo da cultura 
é padrão, e no caso do presente experimento, o valor máximo obtido foi semelhante àquele de SILVA et alii (1974) que tra balharam com dois cultivares de milho, mas foi superior ao en contrado por LOPES e LOPES (1977) e inferior aos de WILLIAMS et alii (1965). Assumindo como vālida a equação (1) para a produtividade biológica ao longo do ciclo da cultura, é evidente que, com base na definição da taxa de crescimento da cultura (equação 2), o gráfico resultante deste parāmetro ao longo do tempo, seria uma limba paralola ao oixo das abcjssas, com o valor constante da ordonala igual do couficionte angular da equação 1 (Eiguras 15 e 16). A Figura 15 mostra os valores constantes de TCC, ao longo do ciclo da cultura, para os três espaçamentos estudados no solo, que foi prepara do convencionalmente, e a Figura 16, as mesmas informações, porém, para o solo subsolado. Como já foi discutido anteriormente, não houve praticamente diferença entre os diversos tratamentos, no que diz respeito ao PB ao longo do tempo (F guras 13 e 14). Consequentemente, o mesmo deve ocorrer para o caso da taxa de crescimento da cultura. Em termos globais isto é verdade, mas cm termos médios, podo-sc dizer que exis te uma ligeira diferença entre os TCC constantes para os tratamentos estudados, notadamente no caso do tratamento conven cional. Neste caso, a tendência é de um aumento da TCC com o aumento do espaçamento entre-linhas. Esta situação (TCC constante ao longo do tempo) é aparentemente fora dos padröes normais existentes na literatura, nos quais, devido à forma 
sigmóide de PB $x$ t, não leva a um valor constante de TCC $x$ e sim a uma curva de diferentes formas, dependendo doestádio da cultura estudado, conforme mostram diversos trabalhos, cọ mo ALVIM e ALVIM (1969), LOPES e MAESTRI (1973), LOPES e LOPES (1977) e MACHADO et alii (1982). No entanto, a adoção desta relação linear do PB $x t$, que leva a TCC constante, tem um respaldo estatistico, de a regressão linear ter fornecido um bom valor de $\mathrm{R}^{2}$, além do que, quando se calculou a taxa de crescimento da cultura média a partir dos pontos experimentais, pela equação (12), o que se obteve foi uma variabilidade muito grande dos resultados, que um valor constante médio poderia ser mais representativo do que qualquer outra curva. Esta dispersão dos dados de TCC são os pontos das Figuras 15 e 16. Como não houve indicações de que pudessem afirmar que os tratamentos sejam diferentes, apenas com intui to de tentar visualizar melhor os detalhes da TCC (que a literatura não considera constante ao longo do ciclo de uma cuI tura), tracou-se manualmente a curva média de todos os trata mentos, que pode ser vista nas Figuras 15 e 16 . Analisando os dados em termos desta curva, o que se pode dizer é que re almente existe um aumentó da TCC dos 14 aos 44 dias após a emergência, e a partir deste ponto decresce e se torna prati camente constante até o final do ciclo. Com isto, pode-se dizer que em termos médios, também no caso deste experimento, desconsiderando a estatistica, a TCC começa baixa, se eleva até um māximo e depois decresce até o final do ciclo da cul tura. 
Apesar da produtividade biológica, como foi discutido anteriormente, não ter sidobem representada por uma linha reta, principalmente nos estádios iniciais de desenvolvimento da cultura, a utilização da equação (5) para o cálculo da taxa de crescimento relativo, que considera a existência de uma relação linear entre $\mathrm{PB} x \mathrm{t}$, mostrou um bom ajuste com os dados experimentais calculados de acordo com o descrito no item 4.5.4, o que pode ser visualizado nas Figu ras 17 e 18, que mostram as curvas obtidas a partir da equa ção (5) e os valores obtidos experimentalmente (equação 13 ). Através das figuras se observa gue a taxa de crescimento relativo foi decrescente com o tempo, como era esperado em fun ção da literatura (LOPES E MAESTRI, 1973; SILVA et alii, 1974; MACHADO et alii, 1982). No entanto, fazendo-se uma análise semelhante àquela realizada para a TCC, caso fosse traçada manualmente a curva média de todos os tratamentos, verificase para os tratamentos estudados que, no período de 14 a 44 dias apōs a emergência, a TCR cresce dos 14 aos 24 dias, decaindo posteriormente.

Com respeito aos resultados especificos do pre sente experimento, a comparação entre as curvas de TCR $x \quad t$ para cada tipo de preparo do solo e a comparação destas curvas entre os dois tipos de preparo, mostra à semelhança da produtividade biológica, indice de ārea foliar e da taxa de crescimento da cultura, não existir diferença entre os diversos tratamentos, ou seja, a subsolagem não modificou o com 
portamento da taxa de crescimento relativo, assim como o espaçamento também não o fez. À semelhança da TCC e da TCR, e xiste também para a taxa de assimilação líquida, equações que calculam o seu valor médio num determinado perỉodo de tempo, pela integração da equação (6), durante este perỉodo. A mais utilizada destas equações assume que deva existir uma relação linear entre $\mathrm{PB} \times \mathrm{A}$. Como no presente caso não existiu essa relação linear, porque a área foliar variou de uma forma quadrática com o tempo e a produtividade biológica de uma forma linear, não foram realizados os cálculos da taxa de as similação líquida média. Portánto, a discussão restringirse-á apenas às curvas obtidas a partir da equação (8). AnaIisando-se as curvas das Figuras 19 e 20, observa-se que para ambos os preparos de solo, o valor da taxa de assimilação Iíquida, em qualquer tempo ao iongo do ciclo da cultura, foi sempre maior com o aumento do espaçamento. No entanto, devi do à dispersão dos dados para os outros parâmetros estudados, pode-se dizer que praticamente esta diferença inexiste. Outro ponto a ser considerado é o comportamento das curvas; devido estas terem sido calculadas a partir da equação (8), de veriam ser semelhantes, tendo em vista que, para todos os tra tamentos, a taxa de crescimento da cultura e índice de ärea foliar se comportarem semelhantemente. A diminuição da taxa de assimilação líquida com o aumento do índice de àrea foliar tambēm foi verificada por wILLIAMS et alii (1965). Não levando em consideração a dispersão dos dados que obscurescessem a sua interpretação, ao analisar as curvas da razão 
de ārea foliar apresentadas nas Figuras 21 e 22, para os preparos de solo convencional e com subsolagem, respectivamente, nos diversos espaçamentos estudados, e definidos com base na equação (1l), verifica-se que o preparo do solo não teve nenhuma influência neste parâmetro. Entretanto, o espaçamento mostra que, embora de uma maneira não muito pronunciada, teve influência na razão de área foliar. Nota-se pelas curvas das Figuras 21 e 22, que o aumento do espaçamento diminuiu a razão de área foliar ao longo do ciclo da cultura, principal mente no inicio do ciclo e com maior intensidade no tratamen to convencional. Ponto importante a ser frisado com relação aos espaçamentos em ambos os preparos do solo, é que o comportamento da razão de ārea foliar em relação ao comportamen to da taxa de assimilação líquida são inversos. Isto é, para os dois preparos de solo, a razão de área foliar é maior para as plantas do espaçamento menor, ao mesmo tempo que apresentam uma menor taxa de assimilação líquida, enquanto que as plantas do maior espaçamento, com menor razão de área foliar, apresentam uma maior taxa de assimilaçäo líquida.Cer tamente, este fato não se deve ao nümero de folhas das plantas destes tratamentos (Tabela 2), mas a uma menor absorção de energia solar por parte destas plantas com menor espaçamento. Este maior sombreamento entre as folhas no espaçamen to menor, ocorreu devido à proximidade das linhas de plantio, ocasionando uma menor distribuição de luz no dossel e, conse quentemente, uma menor taxa de assimilação líquida. Quanto 
aos valores da razão de área foliar serem maiores no início do estádio vegetativo, para todos os tratamentos estudados, provavelmente se deve ao fato de que, na fase inicial, a maior parte do material fotossintetizante foi convertido em fo lhas, visando maior captação da radiação solar disponível. Posteriormente, a razão de ārea foliar decresce, devido a uma maior acumulação de matéria seca no colmo e espiga. Por outro lado, ao se analisar os valores médios da razão de àrea foliar, verifica-se que os encontrados por SILVA et alii. (1974) foram superiores àqueles encontrados neste experimento, apesar de haver semelhança no comportamento das curvas. 


\section{CONCLUSÕES}

Para as condições em que foi conduzido este experimento, pode-se concluir que:

- A subsolagem, em comparação com o preparo do solo convencional, não tem influência sobre nenhum dos fa tores fisiológicos estudados.

- Com relação aos espaçamentos estudados, o que apresenta maior produção é o de $1,10 \mathrm{~m}$, para ambos os preparos do solo; portanto, pode-se dizer que este é o melhor espaçamento dos três estudados $(0,70 ; 0,90 \mathrm{e} 1,10 \mathrm{~m})$.

- Os estádios fenológicos da cultura não foram afetados pelos espaçamentos estudados, muito embora, em termos médios, houvesse variações dos parâmetros fisiológi$\cos$. 
- Para o sistema radicular, o solo que recebeu a subsolagem o apresentou mais profundo, apesar do seu desenvolvimento ter sido satisfatório para ambos os preparos do solo (subsolagem e convencional).

- Os problemas metodológicos encontrados para coleta e análise dos dados, em um estudo usando a análise quantitativa de crescimento são: (i) aumentar o número de re petições na coleta de plantas; (ii) a def́inição prévia das áreas de coleta do material; (iii) na separação da massa de matéria seca da pa'rte aérea das plantas o grande volume de material para secagem; (iv) a coleta de solo com raízes do perfil, a separação destas raizes do solo e sua respectiva limpeza, não apresentam metodologia consistente, além de ser muito trabalhosa; (v) para análise dos dados as fórmulas pre conizadas para valores médios de TCC, TAL e TCR, não ajustaram satisfatoriamente para as condições deste experimento. 


\section{LITERATURA CITADA}

ALESSI, J. e J.F. POWER, 1974. Effects of plant population, row spacing and relative maturity on dryland corn in the Northern Plains. I. Corn forage and grain yield. Agronomy Journal, 66: $316-319$.

ALESSI, J. e J.F. POWER, 1975. Effect of plant spacing on phenological development of early and midseason corn hybrids in a semiarid region. Crop science, 15: 179-182.

ALLISON, J.C.S., 1964a. A comparison between maize and wheat in respect of leaf area after flowering and grain growth. Journal of Agricultural Science, 63: 1-4.

ALLISON, J.C.S., 1964b. Physiological studies of the postflowering period in Zea mays L. University of London. (Tese de Ph.D.) . 
ALOISI SOBRINHO, J. e H.V. ARRUDA, 1960. Efeito do preparo do solo na produção do milho. Bragantia, 19: 215-219.

ALVIM, R. e P.T. ALVIM, 1969. Efeito da densidade de plantio no aproveitamento da energia luminosa pelo milho (Zea mays L.) e pelo feijão (Phaseolus vulgaris L.), em culturas exclusivas e consorciadas. Turrialba, 19: 389-393.

BAKER, D.N. e R.B. MUSGRAVE, 1964. Photosynthesis under field conditions. V. Further plant chamber studies of the effects of light on corn. Crop Science, 4: 127-130.

BENEZ, S.H., C. PIEDADE Jr., C.A. GAMERO e A.E. KLAR, 1979 . Preparo do solo e lotações na cultura do milho lzea mays L.). Eng. Agric., 3: 21-28.

BEZERRA DE OLIVEIRA, L., 1967. O estudo físico do solo e a aplicação racional de técnicas conservacionistas. Boletim Técnico Pesquisa Agropecuária Brasileira. Rio de Janeiro. Vol. 2 .

BLACKMAN, V.H., 1919. The compound interest law and plant growth. Ann. Bot., 33: 353-360.

BLACKMAN, G.E., 1968. The application of the concepts of growth to the assessment of productivity. In: UNESCO. Functioning of terrestrial ecosystems at the primary production level. Paris, p. 243-259. 
BOHM, W., 1979. Methods of studying root systems. Springer -Verlag Berlin Heidelberg. New York. 128 p.

BONNER, J. e A.W. GALSTON, 1955. Principles of plant

physiology. W.H. Freeman and Company Publishers. San Francisco-Cal.

BRIGGS, G.E., R. KIDD e C. WEST, 1920. Quantitative analysis of plant growth. Ann. appl. Biol., 7: 103-123, 202-223.

CANECHIO FILHO, V. e T.C. ALMEIDA, 1973. Principais culturas, t.II. Campinas, Instituto Campineiro de Ensino Agrí cola. $405 \mathrm{p}$.

CHANG, JEN-HU, 1968. Climate and agriculture. An ecological survey. Aldine Publishing Chicago. 304 p.

CHING CHOY, W., J.F. STONE e J.E. GARSTON, 1977. ROW spacing and direction effects on water uptake characteristics of peanuts. Soil Sci. Soc. Am. J., 41: 428-532.

CRUZ, G. e C. TAMES, 1972. Desarollo y distribuicion del sistema radicular del trigo y maiz evaluado en condiciones de campo. Anales. Instituto Nacional de Investigaciones Agrárias. Serie Produccion Vegetal, Madrid, (2): 75-101.

DALE, R.F. e R.H. SHAW, 1965. Effect on corn yields of moisture stress and stand at two fertility levels. Agronomy Journal, 57: 475-479. 
DOPPLER, W., 1983. Plant research and development. In: Irrigation as a basis for development. Institute for Scientific Co-operation, Tubingen, p. 26-36.

DUNCAN, W.G., R.S. LOOMIS, W.A. WILLIAMS e R. HANAV, 1967. A model for simulating photosynthesis in plant communities. Hilgardia, 38: 181-205.

DUNCAN, W.G., 1975. Maize. In: EVANS, L.T. Crop physiology some case histories. London, Cambridge University Press, p. 23-50.

EAGLES, C.F., 1971a. Changes in net assimilation rate and leaf-area ratio with time in Dactylis glomerata. Ann. Bot., $35: 63-74$.

ESPINOZA, W., J. AZEVEDO e I.A. ROCHA, 1980. Densidade de plantio e irrigação suplementar na resposta de três varie dades de milho ao déficit hídrico na região dos cerrados. Pesquisa Agropecuária Brasileira, 15: 85-95.

ESPINOZA, W., 1982. Resposta de doze cultivares de milho ao déficit hídrico num Latossolo Vermelho-Escuro (Typic haplustox) de cerrados do Distrito Federal. Pesquisa Agropecuária Brasileira, 17: 905-915.

EVANS, G.C., 1972. The quantitative analysis of plant growth. England, Oxford. Blackwell Scientific Publications. 
FISHER, R.A., 1921. Some remarks on the methods formulated in a recent article on the quantitative analysis of plant growth. Ann. Appl. Biol., 7: 367-372.

FOTH, H.D., 1962. Root and top growth of corn. Agronomy Journal, 54: 49-52.

GALVÃO, J.D., S.S. BRANDÃO e F.R. GOMES, 1969. Efeito da população de plantas e níveis de nitrogênio sobre a produ ção de grãos e sobre o peso médio das espigas de milho. Experimentiae, 9: 39-82.

GALVÃO, J.D. e E. PATERNIANI, 1975. Comportamento do milho "Piranão" (Braquítico-2) e de milhos de Porte Normal em diferentes níveis de nitrogênio e populações de plantas. Experimentiae, 20: 17-52.

GERARD, C.J., P. SEXTON e G. SHAW, 1982. Physical factors influencing soil strengh and root growth. Agronomy Journal, 74: 875-879.

GREGORY, F.G., 1926. The effect of climatic conditions on the growth of barley. Ann. Bot., 40: 1-26.

HANWAY, J.J., 1963. Growth stages of corn (Zea mays L.). Agronomy Journal, 55: 487-492.

HILER, E.A., T.A. HOWEL, R.B. LEWIS e R.P. BOOS, 1974 . Irrigation timing by the stress day index method. Trans. ASAE, 17: 393-398. 
HUNT, R., 1978. Plant growth analysis. The Institute of Biology's Studies in Biology no $96.68 \mathrm{p}$.

KVET, J., J.P. ONDOK, J. NECAS e P.G. JARVIS, 1971. Methods of growth analysis. In: SESTAK, Z. et alii, Eds. Plant photosynthetic production. Manual of methods. Haia, Dr. W. Junk N.V. Publishers. p. 343-391.

LEITE, D.R. e E. PATERNIANI, 1973. Comportamento de milho (Zea mays L.) braquitico-2 em diferentes densidades de plantio. Relatōrio Científico Inst. Genética-ESAL凡/USP. Piracicaba, SP, 7: 74-82.

LIBARDI, P.L., 1984. Balanço de nitrogênio em culturas agrí colas e desvios encontrados na sua quantificação. Piraci caba, ESALQ/USP, $130 \mathrm{p}$. (Tese de Livre-Docência) .

LOOMIS, R.S. e W.A. WILLIAMS, 1963. Maximum crop productivi ty: an estimate. Crop Science, 3: 67-72.

LOPES, O. e F.N. LOPES, 1977. Análise de crescimento e conversão da energia solar em dois híbridos de milho Zea mays L.). Revista Ceres, 24: 289-296.

LOPES, N.F. e M. MAESTRI, 1973. Análise de crescimento e conversão da energia solar em populações de milho I Zea mays L.) em Viçosa, Minas Gerais. Revista Ceres, 20:189 -201 . 
MACHADO, E.C., A.R. PEREIRA, J.I. FAHL, H.V. ARRUDA, W.J. SILVA e J.P.F. TEIXEIRA, 1982. Análise quantitativa de crescimento de quatro variedades de milho em três densida des de plantio, através de funções matemáticas ajustadas. Pesquisa Agropecuária Brasileira, 17: 825-833.

MAGALHÃES, A.C.N., 1979. Análise quantitativa do crescimento. In: FERRI, M.G., Ed. Fisiologia vegetal. São Pau10, EDUSP, Vol. 1, p. 331-350.

MARQUES, J.Q.A. E J. BERTONI, 1961. Sistemas de preparo do sọlo em relação à produção e à erosão. Bragantia, 20 : 403-459.

MCPHERSON, H.G. e J.S. BOYER, 1977. Regulation of grain yield by photosynthesis in maize subjected to a water deficiency. Agronomy Journal, 69: 714-718.

MEDEIROS, M.C. e A.M. SCHLEHUBER, 1971. Produção de grãos e componentes da produção das variedades brasileiras de tri go. Pesquisa Agropecuária Brasileira, 6: 46-52.

MENGEL, D.B. e S.A. BARBER, 1974. Development and distribution of the corn root system under field conditions. Agronomy Journal, 66: 341-344.

MOLI, R.H. e E.J. KAMPRATH, 1977. Effects of population density upon agronomic traicts associated with genetic increases in yield of Zea mays L. Agronomy Journal, 69: $81-84$ 
MONTEITH, J.L., 1969. Light interception and radiative exchange in crop stands. In: EASTIN, J.D. et alii, Eds. Physiological aspects of crop yields. Madison, USA. p. 89-111.

MONTGOMERY, E.G., isii. Currelation studies of corn. S.1. Nebraska Agr. Sta., Annual Report, 24. p. 109-159.

MOSS, D.N., R.B. MUSGRAVE e E.R. LEMON, 1961. Photosynthesis underfield conditions. III. Some effects of light, carbon dioxide, temperature and soil moisture on photosynthesis, respiration and transpiration corn. Crop Science, 1: 83-196.

MUDSTOCK, C.M., 1978. Efeitos de espaçamentos entre-linhas e de populações de plantas em milho (Zea mays L.) de tipo precoce. Pesquisa Agropecuária Brasileira, 13: 13-18.

ORTOLANI, A.F., O. COAN, J. AYALA OSUNA E D.A. BANZATTO, 1981. Avaliação da resistência do milho (Zea mays L.) ao acamamento, em diferentes sistemas de preparo do solo. Cientifica, 9 : 215-219.

PERIGAUD, S., 1965. Effet du résistance mechanique et du manque d'oxygéne sur le développment des racine. Compt. Rend. Acad. Agric. France, 51: 1209-1220. 
PRIMAVESI, A., 1964. Wheat crops in relation with improving soil structures and root development. VIII Intern. Contr. Soil Sci. Trans. Bucharest, IV: 879-890.

PRIMAVESI, A. e A.M. PRIMAVESI, 1966. Causas de resultados incertos de adubações químicas feitas somente na base da análise química do solo. Bodenkultur Wien, 17: 34-38.

PRIMAVESI, A.M. e A. PRIMAVESI, 1971. Influēncia da técnica de plantio no rendimento de milho (Zea mays L.). Revista do Centro de Ciễidás Rurais UPSM, 1: 45-58.

RADFORD, P.J., 1967. Growth analysis formulae: their use and abuse. Crop Science, 72: 171-175.

RANZANI, G., O. FREIRE e T. KINJO, 1966. Levantamento da carta de solos do municipio de Piracicaba. Piracicaba, ESALQ/USP, $85 \mathrm{p}$. (mimeografado).

REIS, G.G. e M.W. MULLER, 1979. Análise de crescimento de plantas, mensuração do crescimento. Faculdade de ciēncias Agrárias do Pará, Serviço de Documentação e Informacão. 39 p.

RHODES, H.F., 1962. El uso eficaz dellagua para la produccion de maiz. Agricultura de las Americas, 11: 50-52. 
RICHARDS, F.J., 1969. The quantitative analysis of growth. In: STEWARD, F.C., Ed. Plant physiology, a treatise. Academic Press, London. Provides in-depth coverage of the process of dry weight increase, from a mathematical point of view. p. 1-76.

ROSSIELLO, R.O.P., M.S. FERNANDES E J.P.O. FLORES, 1981. Efeitos da deficiência hídrica sobre o crescimento e a acumulação de carboidratos solúveis em milho. Pesquisa Agropecuária Brasileira, 16: 561-566.

RUMAWAS, F., B.O. BLAIR e R.J. BULA, 1971. Microenvironment and plant characteristics of corn (Zea mays L.) planted at two row spacings. Crop Science, 11: 320-323.

SA LEITE, C.A., 1959. Pesquisas agrícolas com milho: porto Alegre. Secretaria da Agricultura, p. 27-41.

SILVA, W.J., J.C. MONTOJOS e R.A. PERGIRA, 1974. Análise de crescimento em dois híbridos simples de milho avaliada em duas densidades de população. Ciência e Cultura, 26: 360 $-365$

STOSKOPF, N.C. e E. REINBERGS, 1966. The basis of breeding for yield in wheat. Wheat Newsletter, Canada Department of Agriculture, 13: 13-20.

SWAN, J.B. E D.R. HICKS, 1972. Irrigated corn production. S.1. University of Minnesota. Fxtension lolder, 263. 
TANNER, C.B., A.E. PETERSON e J.R. LOVE, 1960. Radiant energy exchange in a corn field. Agronomy Journal, 52 : $373-378$.

TAYLOR, H.M., A.P. MATHERS e F.B. LOTSPEICH, 1964. Pans in the Southern plaine soil. Why root-restricting pans occure. Agronomy Journal, 56: 328-332.

VIEGAS, G.P., 1980. Práticas culturais. In: PATERNIANI, E., Ed. Melhoramento e produção do milho no Brasil. Piracicaba, Fundação Cargill, Marprint, Cap. XI, p. 376-428.

VILLA NOVA, N.A., R. VENCOVSKY, J.C. OMETTO e A. DECICO, 1973. Contribuição ao estudo dos ventos da região de Piracicaba. II Semana de Estudos de Meteorologia Agrícola do Paraná. Universidade Federal do Paraná, Curitiba.

WALLAGE, D.H., J.L. OZBUN e H.M. MUNGER, 1972. Physiological genetics of crop yield. Adv. Agron., 24: 97-146.

WATSON, D.J., 1952. The physiological basis of variation in yields. Adv. Agron., 4 : 101-145.

WATSON, D.J., 1956. Leaf growth in relation to crop yield. In: MILTHORPE, F.L., Ed. The growth leaves. London, Butterworths, p. 178-191.

WATSON, D.J., 1958. The dependence of net assimilation rate on leaf area index. Ann. Bot., 22: 37-54. 
WIERSUM, L.K., 1961. Utilization of soil by the plant root system. Plant and Soil, 15: 189-192.

WILLIAMS, W.A., R.S. LOOMIS e C.R. LEPLEY, 1965. Vegetative growth of corn as affected by population density. I. Productivity in relation to interception of solar radiation. II. Components of growth, net assimilation rate and leaf-area index. Crop Science, 5: 211-219.

WINKLER, E.I.G., 1972. Espaçamento quadrangular em milho. In: REUNIÃO BRASILEIRA DE MILHO, 9ạ Recife, p. 185-189. YAO, A.Y.M. e R.H. SHAW, 1964. Effect of plant population and planting pattern of corn on the distribution of net radiation. Agronomy Journal, 56: 165-169. 